\title{
QUÍMICA DOS ALIMENTOS \\ ESTRUTURAS, PROPRIEDADES E TRANSFORMAÇÕES
}

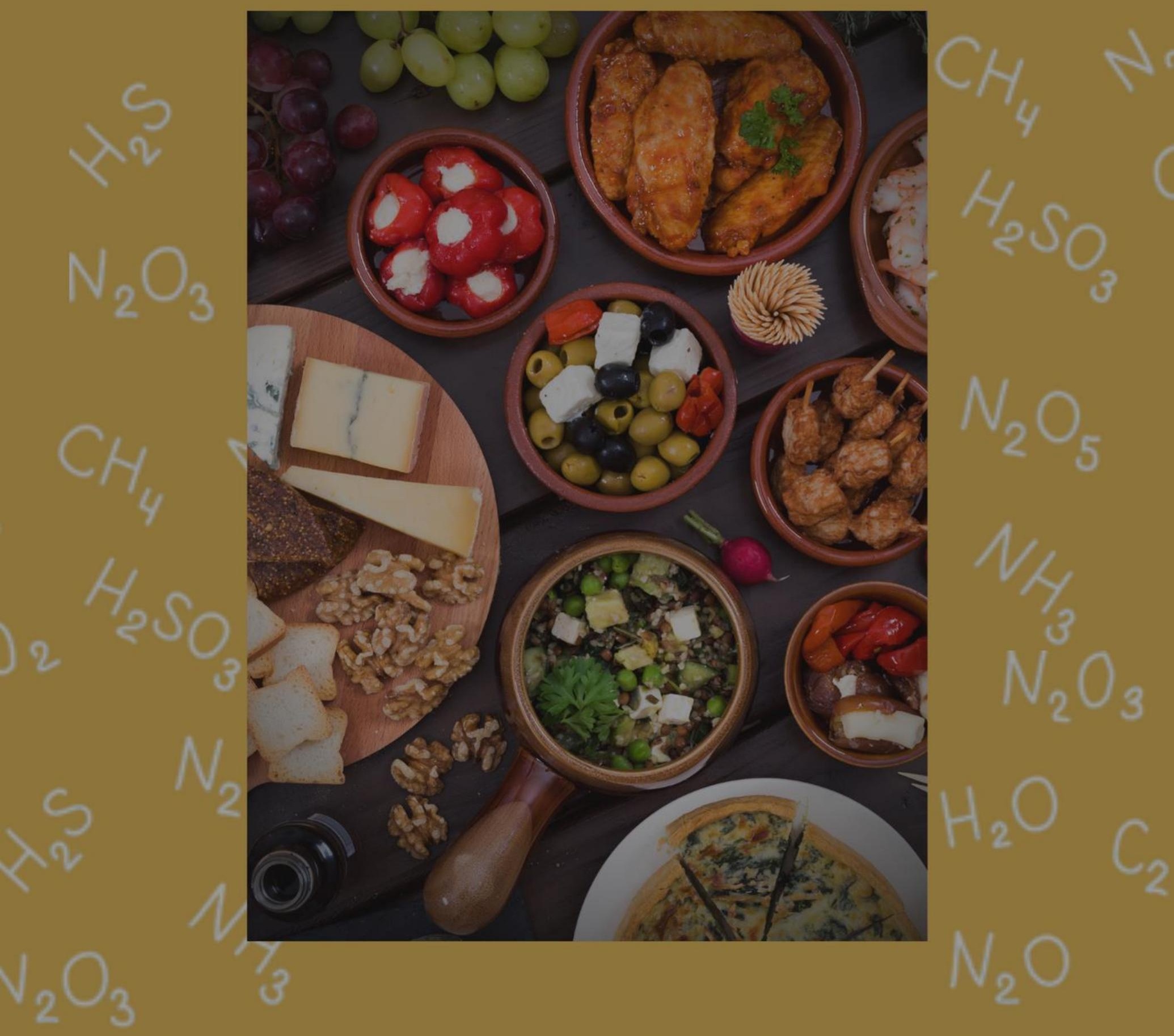

MARIA DA CONCEIÇÃO TAVARES CAVALCANTI LIBERATO
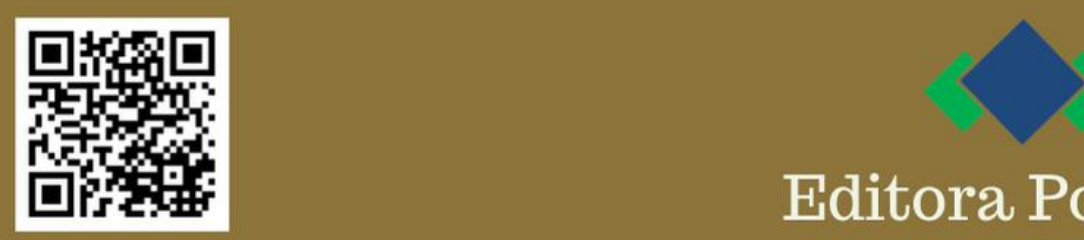

Editora Poisson 
Maria da Conceição Tavares Cavalcanti Liberato

\section{QUÍMICA DOS ALIMENTOS}

Estruturas, Propriedades e Transformações

1a Edição

Belo Horizonte

Poisson

2020 
Editor Chefe: Dr. Darly Fernando Andrade

\section{Conselho Editorial}

Dr. Antônio Artur de Souza - Universidade Federal de Minas Gerais

Ms. Davilson Eduardo Andrade

Dra. Elizângela de Jesus Oliveira - Universidade Federal do Amazonas

Msc. Fabiane dos Santos

Dr. José Eduardo Ferreira Lopes - Universidade Federal de Uberlândia

Dr. Otaviano Francisco Neves - Pontifícia Universidade Católica de Minas Gerais

Dr. Luiz Cláudio de Lima - Universidade FUMEC

Dr. Nelson Ferreira Filho - Faculdades Kennedy

Ms. Valdiney Alves de Oliveira - Universidade Federal de Uberlândia

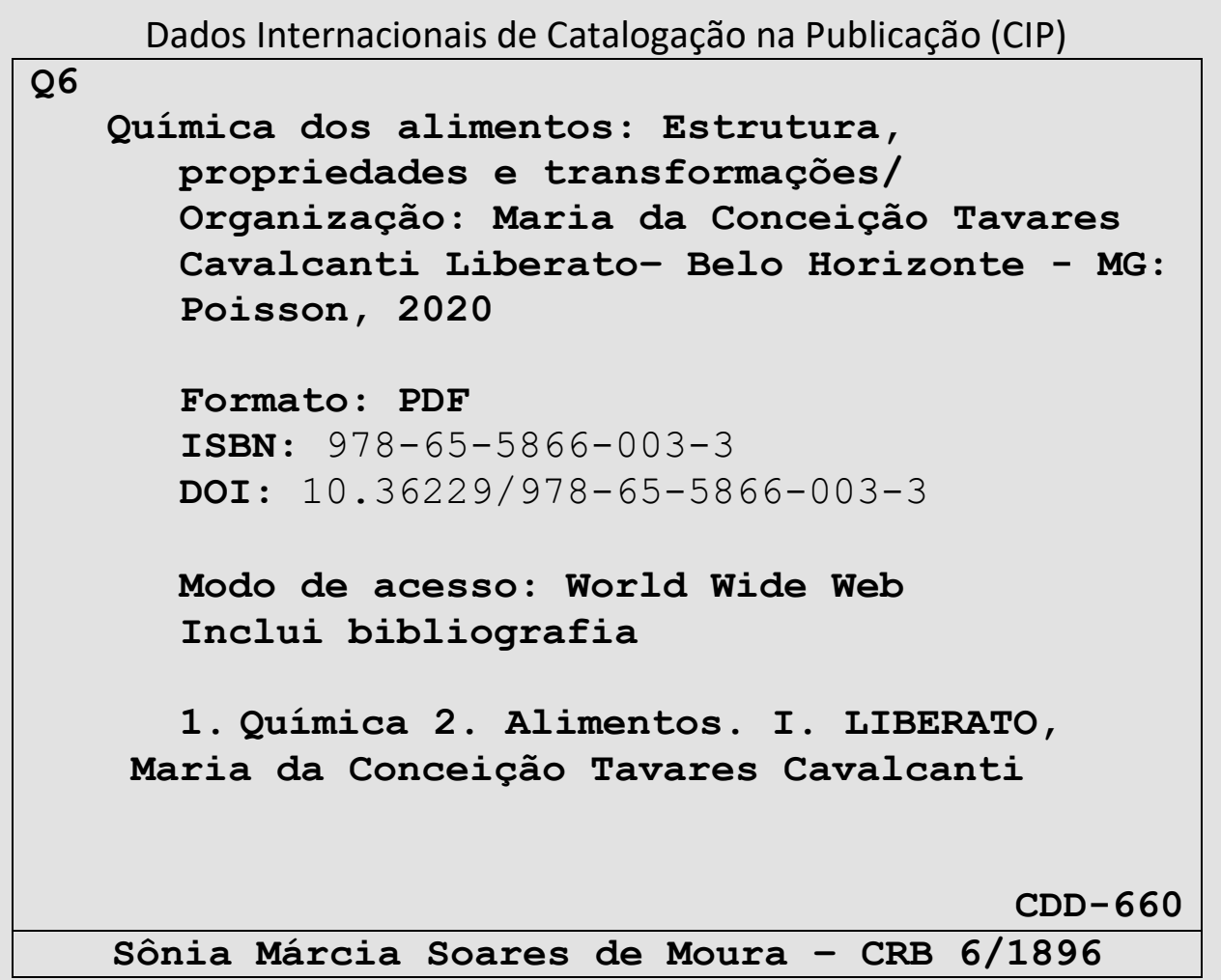

O conteúdo dos artigos e seus dados em sua forma, correção e confiabilidade são de responsabilidade exclusiva dos seus respectivos autores.

www.poisson.com.br

contato@poisson.com.br 


\section{Informações sobre a autora}

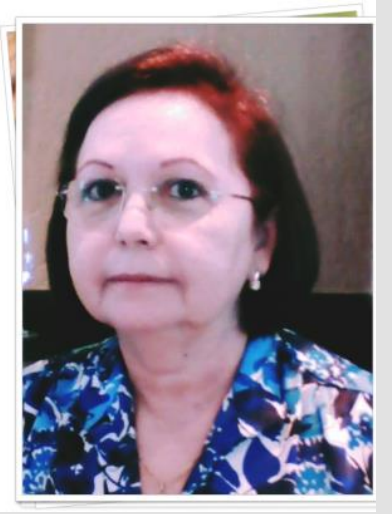

\section{Dra. Maria da Conceição Tavares Cavalcanti Liberato}

Graduada em Química Industrial pela Universidade Federal do Ceará (UFC), Especialista em Química Orgânica pela Universidade Federal do Rio de Janeiro (UFRJ), Mestre em Tecnologia de Alimentos pela Universidade Federal do Ceará (UFC), Doutora em Biotecnologia pela Rede Nordeste de Biotecnologia (RENORBIO). Professora Associada com Dedicação Exclusiva do Curso de Licenciatura em Química da Universidade Estadual do Ceará (UECE) e Professora colaboradora do Mestrado em Ciências Naturais da Universidade Estadual do Ceará (UECE); Coordenadora do Laboratório de Bioquímica e Biotecnologia da Universidade Estadual do Ceará (LABBIOTEC). Representante da Universidade Estadual do Ceará na Câmara Temática do Mel (CTMel) da Agência de Desenvolvimento do Estado do Ceará (ADECE). Sócia da Associação Brasileira de Química (ABQ) e da Sociedade Brasileira de Química (SBQ). 


\section{Agradecimentos}

Escrever esse livro foi muito recompensador já que o processo ocorreu através das aulas na disciplina de Química dos Alimentos para o Curso de Química da Universidade Estadual do Ceará, quando ele foi tomando a forma final, determinada pelo interesse demonstrado pelos alunos.

De forma muito especial agradeço a parceria do meu esposo Francisco José Liberato, grande incentivador e primeiro leitor dessa obra.

Quero agradecer também a todos os amigos do Centro de Ciências e Tecnologia (CCT) da Universidade Estadual do Ceará (UECE) em especial ao seu Diretor Prof. Luciano Cavalcante, aos amigos de todas as horas, Dilma, Jacqueline, Marluce, Samuel, Sávio, Cauby, Tom, Vanda e Solange, pela amizade, atenção e presteza nos momentos necessários. Agradeço também a todos os alunos bolsistas, monitores, e voluntários do Laboratório de Bioquímica e Biotecnologia (LABBIOTEC) do Curso de Licenciatura em Química pelo interesse e dedicação à causa da Ciência.

A todos vocês que trilharam comigo esse caminho durante tantos semestres em que leciono essa disciplina meus sinceros agradecimentos. 


\section{Prefácio}

Acontecimentos iniciados no século XIX e intensificados no século XX com a industrialização crescente, desenvolvimento de novas tecnologias e descoberta de novos produtos e substâncias trouxeram às pessoas a possibilidade de consumir alimentos encontrados à venda na forma de enlatados, congelados, desidratados, liofilizados, cortados, picados, higienizados, com adição de nutrientes, sem açúcar, sem gorduras, etc., tendências resultantes do estilo de vida atual. Nesses tempos de globalização e grande circulação de produtos alimentícios, a Química assumiu o papel primordial de permitir conhecer e classificar os alimentos. Esse conhecimento possibilitou processar os alimentos de maneiras diversas, gerando uma grande variedade de produtos, facilitando o armazenamento, o transporte e estimulando o consumo, além de contribuir para a evolução do setor agrícola. Ensinar Química dos Alimentos é como construir um edifício de conhecimento em pessoas que não são orientadas a fazer escolhas corretas que levem à uma vida saudável. Quando novas perspectivas são apresentadas para crianças e jovens, no aspecto alimentar, ocorre uma forma de contribuir para surgimento de gerações amadurecidas, donas de discernimento e não influenciáveis pela beleza de propagandas. 


\section{SUMÁRIO}

A Química na Evolução do Consumo e na Indústria de Alimentos

Introdução à Química dos Alimentos.

Capítulo 1 - Água.

Capítulo 2 - Carboidratos.

Capítulo 3 - Lipídeos

Capítulo 4 - Proteínas

Capítulo 5 - Enzimas.

Capítulo 6 - Pigmentos e Corantes.

Referências 


\section{A QUÍMICA NA EVOLUÇÃO DO CONSUMO E NA INDÚSTRIA DE ALIMENTOS}

A Química perpassou a história dos alimentos, desde os primeiros indicativos de fraudes - com adição de água ao leite, no século XVIII - aos mistérios de hoje, desvendados por pesquisas químicas e bioquímicas bem como pela evolução da tecnologia dos alimentos.

A Química esclarece a composição dos macronutrientes e dos micronutrientes, qualitativamente e quantitativamente; faculta conhecê-los quanto ao valor energético; esclarece as diferenças no sistema de produção e na funcionalidade de cada um deles numa preparação; justifica os padrões da legislação; classifica-os em perecíveis ou semi-perecíveis e permite selecionar as técnicas de conservação apropriadas.

$\mathrm{Na}$ indústria e nos serviços de alimentação, conhecer a Química dos alimentos possibilita criar produtos, otimizar os existentes, modificar os produtos convencionais quanto à retirada ou ao acréscimo de carboidratos, gorduras, sais, proteínas, mantendo suas características estéticas e sensoriais. Na culinária, compreende-se por que alimentos cozidos em fornos de micro-ondas diferem dos preparados nos convencionais forno e fogão: cozinhar tem tudo a ver com ciência.

A ciência dos alimentos estuda os fenômenos que ocorrem nas preparações, baseada no conhecimento das propriedades físico-químicas dos componentes alimentares, das condições a que essas substâncias estão sujeitas na cocção, na natureza das reações causadas por tais fatores e no efeito de substâncias adicionadas: é a alquimia dos alimentos.

Nesse mundo de globalização e de grande circulação de produtos alimentícios, a Química teve o papel primordial de permitir conhecer e classificar os alimentos. Esse conhecimento possibilitou processar os alimentos de maneiras diversas, gerar uma variedade de produtos, facilitar o armazenamento e o transporte e estimular o surgimento de novos espaços de consumo, como supermercados e restaurantes, além de contribuir para a evolução do setor agrícola. 


\section{Introdução à química dos alimentos}

A "Química dos Alimentos" estuda a estrutura, as propriedades e as transformações dos alimentos e seus componentes. Na maioria dos casos, os alimentos são sistemas biológicos de origem animal ou vegetal de composição complexa, sujeitos a múltiplas modificações quando são isolados, preparados, armazenados, consumidos e metabolizados. Além dos conceitos de Química, para estudar alimentos precisa-se ter também conhecimentos de Bioquímica, conhecimentos sobre a obtenção, elaboração e conservação dos mesmos, bem como sobre a presença de compostos tóxicos, nutrição e a legislação para cada tipo de alimento.

Embora a origem da Química de Alimentos reporte-se à antiguidade, as descobertas mais relevantes, tiveram início no final do século XVIII. Durante o período de 1780 a 1850, diversos químicos fizeram descobertas importantes, muitas delas relacionadas aos alimentos. Para os químicos dos séculos XVIII e XIX, compreender a natureza química dos alimentos era o objetivo primordial, pois acreditavam que assim poderiam elevar o nível de saúde e de prosperidade dos povos.

Carl Willelm Scheele (1742-1786), por exemplo, descobriu o cloro, o glicerol além de isolar e determinar propriedades da lactose, desenvolver um método para preservar vinagre por aplicação de calor, isolou o ácido cítrico do suco de limão, o ácido málico de maçãs e testou 20 frutas comuns para a presença dos ácidos málico, cítrico e tartárico.

Dos químicos de alimentos se exige hoje uma explicação sobre o comportamento dos componentes de um alimento no armazenamento, no processamento, na cocção e mesmo na boca ou durante a digestão. Muito do estímulo a esse tipo de questionamento vem da indústria de produção de alimentos e das instituições que regulam as atividades industriais. Por exemplo, a observação de que o amido presente em tipo de sobremesa fornece uma certa quantidade de energia tem sido superada em importância pela necessidade de saber que tipo de amido pode dar o grau desejado de consistência, e qual a base molecular das diferenças entre um tipo de amido e outro.

Os alimentos procedem basicamente da natureza. Apesar de se apresentarem com formas e composições diferentes, são sempre compostos especiais, cuja estrutura química possibilita o ataque por enzimas endógenas e dessa forma promove a metabolização com liberação de energia necessária à vida. Assim, pode-se dizer que ALIMENTOS são antes de tudo, substâncias que se consomem inalteradas ou elaboradas devido ao seu conteúdo de nutrientes. Os nutrientes pertencem aos grupos químicos dos lipídeos, carboidratos e proteínas. Porém, eles são consumidos também por seu sabor, aroma ou efeito estimulante de alguns de seus componentes, como por exemplo, a cafeína.

Os alimentos além de gerar energia abastecem o corpo constantemente com proteínas, ajudando na síntese de substâncias endógenas. Por exemplo, a vida média biológica das proteínas plasmáticas é de vários dias, o que significa que durante esse período de tempo a metade delas se desagrega e é trocada por outras novas. Essa regeneração constante de substâncias endógenas requer o abastecimento contínuo de componentes necessários.

O estudo da Química de Alimentos inclui quatro componentes: 1. Determinação das propriedades que são características importantes de um alimento seguro e de elevada qualidade; 2 . Determinação das reações químicas e bioquímicas que influenciam de maneira relevante em termos de perda de qualidade e/ou salubridade do alimento; 3 . Integração dos dois pontos anteriores, de modo a entender como as reações químicas e bioquímicas-chave influenciam na qualidade e na segurança; e 4. Aplicação desse conhecimento a várias situações encontradas durante formulação, processamento e armazenamento de alimentos.

A segurança é o primeiro requisito de qualquer alimento. Isso significa que um alimento deve estar livre de qualquer substância química ou contaminação microbiológica prejudicial no momento de seu consumo. $\mathrm{Na}$ indústria de enlatados, a esterilidade "comercial", aplicada a alimentos de baixa acidez, significa a ausência de esporos viáveis de Clostridium botulinum. Isso pode ser traduzido por um conjunto de condições específicas de aquecimento para um produto específico, em uma embalagem específica. Dados os requisitos de tratamento térmico, é possível selecionar condições específicas de tempo e temperatura para que seja otimizada a retenção de atributos de qualidade. Da mesma forma, em um produto como a manteiga de amendoim, a segurança operacional pode ser considerada, principalmente, como a ausência de aflatoxinas - substâncias carcinogênicas produzidas por algumas espécies de fungos. As etapas da 
prevenção do crescimento do fungo em questão podem ou não interferir na retenção de algum outro atributo de qualidade; ainda assim, as condições que resultam em produtos seguros devem ser empregadas.

Atributos de qualidade de alimentos e algumas alterações, que podem ser sofridas por eles durante processamento e armazenamento, são apresentados na Tabela 1. As modificações que podem ocorrer, com exceção das que envolvem valor nutricional e segurança, são rapidamente percebidas pelo consumidor.

Tabela 1. Classificação das alterações que podem ocorrer durante manipulação, processamento ou armazenamento

\begin{tabular}{|c|l|}
\hline \multicolumn{1}{|c|}{ Atributo } & \multicolumn{1}{c|}{ Alteração } \\
\hline \multirow{3}{*}{ Textura } & $\begin{array}{l}\text { Perda de solubilidade } \\
\text { Perda de capacidade de retenção de água } \\
\text { Endurecimento } \\
\text { Amolecimento }\end{array}$ \\
\hline \multirow{3}{*}{ Sabor } & $\begin{array}{l}\text { Desenvolvimento de rancidez (hidrolítica e oxidativa) } \\
\text { Sabor cozido ou caramelo } \\
\text { Outros odores indesejados } \\
\text { Sabores desejados }\end{array}$ \\
\hline \multirow{2}{*}{ Cor } & $\begin{array}{l}\text { Escurecimento } \\
\text { Branqueamento } \\
\text { Desenvolvimento de cores desejadas (p. ex., escurecimento em produtos cozidos) }\end{array}$ \\
\hline \multirow{2}{*}{ Valor nutricional } & $\begin{array}{l}\text { Perda, degradação ou alteração da biodisponibilidade de protén, } \\
\text { vitaminas, minerais e outros componentes benéficos à saúde }\end{array}$ \\
\hline \multirow{2}{*}{ Segurança } & $\begin{array}{l}\text { Geração de substâncias tóxicas } \\
\text { Desenvolvimento de substâncias com efeito protetor à saúde } \\
\text { Inativação de substâncias tóxicas }\end{array}$ \\
\hline
\end{tabular}

(Fonte: Evangelista, J.; 1998; 2005)

Muitas reações químicas e bioquímicas podem alterar a qualidade ou a segurança do alimento. Algumas dessas reações mais importantes estão listadas na Tabela 2. Cada classe de reação pode envolver diferentes reagentes ou substratos, dependendo especificamente do alimento e das condições particulares de manipulação, processamento ou armazenamento. Elas são tratadas como classes de reações, pois, a natureza geral dos substratos ou reagentes é similar a todos os alimentos. Logo, o escurecimento não enzimático envolve reações de carbonilas, que podem surgir da existência de açúcares redutores ou ser geradas a partir de diversas reações, como por exemplo, a oxidação de ácido ascórbico, hidrólise do amido ou oxidação de lipídeos. A oxidação pode envolver lipídeos, proteínas, vitaminas ou pigmentos e, mais especificamente, a oxidação de lipídeos pode envolver triacilgliceróis em alguns alimentos e fosfolipídeos em outros.

Tabela 2. Algumas das reações químicas e bioquímicas que podem levar à alteração da qualidade ou da segurança dos alimentos

\begin{tabular}{|l|l|}
\multicolumn{1}{|c|}{ Tipo de reação } & \multicolumn{1}{c|}{ Exemplos } \\
\hline Escurecimento não enzimático & Produtos cozidos, secos e de umidade intermediária \\
\hline Escurecimento enzimático & Frutas e vegetais cortados \\
\hline Oxidação & $\begin{array}{l}\text { Lipídeos (odores indesejáveis), degradação de vitaminas, } \\
\text { descoloração de pigmentos, proteínas (perda de valor nutricional) }\end{array}$ \\
\hline Hidrólise & Lipídeos, proteínas, carboidratos, vitaminas, pigmentos \\
\hline Interações com metais & $\begin{array}{l}\text { Complexação (antocianinas), perda de Mg da clorofila, catálise da } \\
\text { oxidação }\end{array}$ \\
\hline Isomerização de lipídeos & Isomerização cis $\rightarrow$ trans, não conjugado >conjugado \\
\hline Ciclização de lipídeos & Ácidos graxos monocíclicos \\
\hline Oxidação e polimerização de lipídeos & Formação de espuma durante a fritura \\
\hline Desnaturalização de proteínas & Coagulação da gema de ovo, inativação de enzimas \\
\hline Interligação entre proteínas & Perda de valor nutricional durante processamento alcalino \\
\hline Síntese e degradação de polissacarídeos & Pós-colheita de plantas \\
\hline Alterações glicolíticas & Pós-colheita do tecido vegetal, pós-morte do tecido animal \\
\hline
\end{tabular}


As reações, listadas na Tabela 3, causam as alterações listadas na Tabela 1. A integração da informação contida em ambas as tabelas pode conduzir ao entendimento das causas de deterioração dos alimentos. A deterioração de um alimento costuma ser constituída por uma série de eventos primários, seguidos de eventos secundários que, por sua vez, tornam-se evidentes pela alteração de atributos de qualidade.

Tabela 3. Exemplos de relações-causa-efeito associadas a alterações em alimentos durante manipulação,

\begin{tabular}{|c|c|c|}
\hline Evento primário & Efeito secundário & Atributo influenciado \\
\hline Hidrólise de lipídeos & $\begin{array}{l}\text { Ácidos graxos livres reagem com } \\
\text { proteínas }\end{array}$ & Textura, sabor, valor nutricional \\
\hline Hidrólise de polissacarídeos & Açúcares reagem com proteínas & Textura, sabor, cor, valor nutricional \\
\hline Oxidação de lipídeos & $\begin{array}{l}\text { Produtos de oxidação reagem com } \\
\text { diversos outros constituintes }\end{array}$ & $\begin{array}{l}\text { Textura, sabor, cor, valor nutricional; } \\
\text { pode ocorrer formação de substancias } \\
\text { tóxicas }\end{array}$ \\
\hline Contusões em frutas & $\begin{array}{l}\text { Ruptura celular, liberação de enzimas, } \\
\text { disponibilidade de oxigênio }\end{array}$ & Textura, cor, valor nutricional \\
\hline $\begin{array}{l}\text { Aquecimento de produtos da } \\
\text { horticultura }\end{array}$ & $\begin{array}{l}\text { Perda de integridade de parede e } \\
\text { membrana celulares, liberação de } \\
\text { ácidos, inativação de enzimas }\end{array}$ & Textura, sabor, cor, valor nutricional \\
\hline $\begin{array}{l}\text { Aquecimento do tecido } \\
\text { muscular }\end{array}$ & $\begin{array}{l}\text { Desnaturação e agregação de proteínas, } \\
\text { inativação de enzimas }\end{array}$ & Textura, sabor, cor, valor nutricional \\
\hline $\begin{array}{l}\text { Conversão cis trans em } \\
\text { lipídeos }\end{array}$ & $\begin{array}{l}\text { Aumento da taxa de polimerização } \\
\text { durante a fritura }\end{array}$ & $\begin{array}{l}\text { Formação excessiva de espuma durante a } \\
\text { fritura, diminuição do valor nutricional e } \\
\text { biodisponibilidade de lipídeos, } \\
\text { solidificação do óleo de fritura }\end{array}$ \\
\hline
\end{tabular}

(Fonte: Evangelista, J.; 1998, 2005)

\section{ANÁLISE DE SITUAÇÕES OCORRIDAS DURANTE O ARMAZENAMENTO E O PROCESSAMENTO DE ALIMENTOS}

\section{TEMPERATURA}

É talvez a variável mais importante em decorrência da sua grande influência em todos os tipos de reações químicas.

\section{TEMPO}

É outro fator importante. Durante o armazenamento de um alimento, costuma-se informar sobre qual período se espera que o alimento mantenha um nível específico de qualidade. Portanto, o interesse é pelo tempo em relação ao total de alterações químicas e/ou microbiológicas que ocorrem durante o período específico de tempo de armazenamento e pelo modo como a combinação das alterações determinam um prazo específico para o armazenamento do produto. Durante o processamento existe interesse em se conhecer o tempo necessário de inativação de uma determinada população de microrganismos ou o tempo necessário para que uma reação ocorra, na extensão desejada. Por exemplo, pode ser de interesse saber quanto tempo é necessário para a produção do escurecimento desejado em chips de batatas durante a fritura. Para tanto deve-se considerar a mudança da temperatura em função do tempo.

\section{$\mathrm{pH}$}

$\mathrm{O}$ pH influencia na velocidade de diversas reações químicas e enzimáticas. Valores extremos de $\mathrm{pH}$ costumam ser necessários para se inibir ostensivamente o crescimento microbiano ou de processos enzimáticos. Essas condições podem acelerar reações catalisadas por ácidos ou bases. Mesmo uma mudança relativamente pequena no pH pode causar alterações importantes na qualidade de alguns alimentos, por exemplo, no músculo. 


\section{COMPOSIÇÃO DO PRODUTO}

É importante, pois determina quais substratos estão disponíveis para transformações químicas.

\section{MANIPULAÇÃO}

0 modo como frutas e vegetais são manipulados no pós-colheita pode influenciar no conteúdo de açúcar, e isso, por sua vez, pode influenciar no grau de escurecimento obtido durante desidratação ou fritura. 0 modo como tecidos animais são manipulados no pós-morte exerce influência sobre velocidade e extensão da glicólise e sobre a degradação de ATP; esses fatores por sua vez, podem influenciar em tempo de armazenamento, rigidez, capacidade de retenção de água, sabor e cor.

\section{ATIVIDADE DE ÁGUA}

Outro fator determinante relacionado à composição do alimento é a atividade de água $\left(a_{w}\right)$. Ela influencia fortemente na velocidade de reações catalisadas por enzimas, na oxidação por lipídeos, no escurecimento não enzimático, na hidrólise da sacarose, na degradação da clorofila, na degradação de antocianinas entre outras. Em produtos industrializados, a composição pode ser controlada pela adição de compostos químicos permitidos, como acidulantes, agentes quelantes, flavorizantes ou antioxidantes, bem como pela remoção de substratos indesejáveis.

\section{COMPOSIÇÃO DA ATMOSFERA}

É importante, em especial, em relação à umidade relativa e ao conteúdo de oxigênio, embora o etileno e o $\mathrm{CO}_{2}$ também sejam importantes durante o armazenamento de tecidos de origem vegetal. Infelizmente, em situações nas quais a exclusão do oxigênio é desejável, essa condição é quase impossível de ser obtida por completo. Em alguns casos, os efeitos deletérios de quantidades residuais de oxigênio tornam-se aparentes durante o armazenamento. Por exemplo, a formação prematura de pequenas quantidades de ácido deidroascórbico (a partir da oxidação do ácido ascórbico) pode resultar em escurecimento pela Reação de Maillard, durante o armazenamento.

\section{LUZ}

Para alguns produtos, a exposição à luz pode ser deletéria. Nesses casos, é adequado que os produtos sejam embalados em material refratário à luz ou que sejam controlados a intensidade e os comprimentos de onda da luz, se possível.

\section{ALIMENTOS E DIETAS}

Atualmente, observa-se um crescimento de variadas formas de alimentação. Por exemplo, os vegetarianos que evitam o consumo, em maior ou menor grau de produtos de origem animal, podem ser chamados de acordo com seu consumo alimentar:

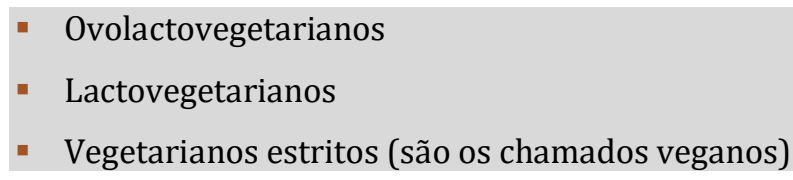

\section{- Alimentos Dietéticos:}

Apresentam a função de diminuir ou aumentar a ingestão de certos nutrientes ou compostos fisiologicamente ativos para pessoas com requerimentos alimentares especiais. Por exemplo, no caso dos diabéticos o açúcar é trocado por substitutos como manitol, sorbitol, xilitol, frutose etc. Enquanto para pessoas com sobrepeso são oferecidos pela indústria de alimentos, edulcorantes (aspartame, ciclamato, sacarina e etc). 


\section{- Alimentos Funcionais}

Ultimamente surgiram no comércio os alimentos chamados de funcionais, que são aqueles que possuem certos elementos adicionais para conseguir efeitos predeterminados. São produtos que contêm quantidades adicionais de vitamina $\mathrm{C}$ e E, de carotenoides, flavonoides, tiocianetos e fibra alimentar como profilaxia contra o câncer; antioxidantes, ácidos graxos poli-insaturados para impedir doenças circulatórias e do coração; cálcio, magnésio, fósforo e vitaminas D e E para evitar osteoporose; bactérias lácteas especiais, ácidos graxos insaturados, aminoácidos e nucleotídeos para estabilizar o sistema imunológico.

No Japão até agora, já foram autorizados mais de 58 produtos conhecidos como alimentos de uso específico para a saúde, como por exemplo: leite pobre em fósforo (para pessoas com problemas renais crônicos), bebidas refrescantes e pudins enriquecidos com certos oligossacarídeos do tipo oligofrutose ou polifrutose (para regenerar a flora intestinal), chiclete com isomaltose ou maltitol contra as cáries dentárias.

\section{- Alimento Probiótico}

As bactérias lácticas do tipo Lactobacillus acidophilus, L. casei, L. delbruckii, bífidobactérias e certos estreptococos, ingeridas no iogurte ou na coalhada colonizam o intestino humano e potencializam a saúde. Constituem o que se chama Alimento Probiótico, que quer dizer possuir um cultivo de bactérias que se encarrega de estabilizar o equilíbrio microbiológico no intestino humano.

\section{- $\quad$ Alimento Prebiótico}

Já a oligofrutose extraída da chicória, é chamado de Alimento Prebiótico, pois estimula a flora bífida no intestino grosso humano, dado que as bífidobacterias podem metabolizar oligofrutoses mediante a enzima $\beta$-frutosidase, que estas contêm. Ao mesmo tempo, são reduzidas, no intestino, o número de bactérias, fusobactérias e clostrídios indesejados. Portanto, os alimentos prebióticos estimulam a flora intestinal, mesmo que sejam fibras alimentares. Os efeitos comprovados até o momento são uma menor frequência de aparecimento de diarreias (por causa dos clostrídios ou depois de tratamento com antibióticos), uma maior tolerância à lactose por pessoas que tem intolerância à lactose, bem como diminuição na concentração de alguns produtos metabólicos e enzimas cancerígenas no intestino grosso.

\section{- Alimentos Nutraceuticos}

Um grupo de alimentos que contêm em sua constituição componentes conhecidos como fármacos são chamados Nutraceuticos.

\section{- Alimentos Transgênicos}

Os Alimentos Transgênicos são aqueles preparados por modificação genética, como por exemplo, milho, trigo, soja e até o fermento para produção de queijos, a renina. Em tempos recentes, foram identificados e isolados dos cromossomos de bezerros, os genes responsáveis pelo fermento coagulante renina, necessário para a fabricação do queijo, e que é encontrado nas mucosas intestinais de bezerros. Sua implantação em bactérias (Escherichia coli, Kluyveromyces lactis ou certas espécies de Aspergillus niger) permitiram a produção do fermento eliminando a busca em matadouros. 


\section{CAPÍTULO}

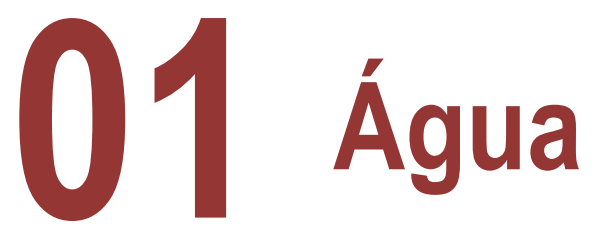

Nos alimentos a água é o mais importante componente por ser o veículo para as reações químicas e bioquímicas. Sua presença é essencial para o desenvolvimento de micro-organismos. Portanto, a preservação de um alimento, sua consistência, aspecto e cor geralmente dependem da quantidade de água presente. A água é uma das substâncias mais simples, porém a mais importante: todas as reações que acontecem no nosso organismo são em soluções aquosas, e as proteínas, membranas, enzimas, mitocôndrias e hormônios somente são funcionais na presença dessa substância. Sem ela a vida na terra não existiria. Ela é tão importante que os gregos a consideravam um dos elementos fundamentais da matéria. Apenas no século XVIII a água foi identificada como um composto químico formado por átomos de hidrogênio e oxigênio.

O conteúdo de água de um alimento é determinado pelo valor total de água que ele contém. Entretanto esse valor não permite saber como estão distribuídas suas propriedades. Para frutas, vegetais, carnes, peixes, leites e ovos, o conteúdo de água varia entre 70,0\% e 95,0\%. Teoricamente, a velocidade de deterioração desses alimentos deveria ser a mesma. Entretanto, é necessário considerar em que grau essa água favorece o desenvolvimento microbiano e como favorece as reações químicas e enzimáticas em cada um deles. Isso permite admitir a existência de moléculas de água com propriedades e distribuição diferentes em um mesmo alimento.

A água é imprescindível à vida seja animal ou vegetal. É um composto que desempenha funções importantes como, por exemplo, estabilizador da temperatura do corpo, transportador de nutrientes e de produtos de degradação, reagente e meio de reação, estabilizador da conformação de polímeros formados por biomoléculas, facilitador do comportamento dinâmico de macromoléculas, etc. A água pode ocorrer como componente intracelular ou extracelular, em vegetais e animais. Os músculos de um adulto têm em média um conteúdo de água de $74 \%$, e os órgãos internos têm cerca de $80 \%$. Com a perda de $10 \%$ de água corporal começam a aparecer os primeiros transtornos funcionais, que levam à morte do indivíduo se essa perda chega a $15 \%$.

Um adulto perde diariamente entre 2 e 2,5 l de água através dos rins, intestinos, pele e pulmões; quantidade essa que não inclui as perdas pela transpiração. Essa água tem que ser recuperada através da alimentação diária, pois os alimentos são compostos por uma porcentagem considerável de água, e pequenas quantidades de água pura. A água apresenta-se com teor variável nos diferentes alimentos (tabela 1). Nas frutas e hortaliças encontram-se de 70 a 95\% de água, na carne cerca de 60 a $80 \%$ e no pão e nas massas cerca de 30 a $45 \%$ de água. É possível supor que nossa alimentação diária contem e 0,7 l de água proveniente dos alimentos e 0,3 l de água que é liberada por oxidação dos componentes dos alimentos.

Tabela 1 - Teores de água de alguns alimentos

\begin{tabular}{|l|c|}
\multicolumn{1}{|c|}{ Alimento } & $\begin{array}{c}\text { Teor de água } \\
\text { (g/100g) }\end{array}$ \\
\hline Carnes & $50-70$ \\
\hline Maçã, laranja & $85-90$ \\
\hline Tomate, morango & $90-95$ \\
\hline Cenoura, batata & $80-90$ \\
\hline Aspargo, lentilha & $90-95$ \\
\hline Arroz cru, milho cru & $12-15$ \\
\hline Leite em pó, ovo desidratado & $9-12$ \\
\hline Queijo prato & $40-45$ \\
\hline Pão francês & $30-35$ \\
\hline Leite & $87-89$ \\
\hline
\end{tabular}

(Fonte: Franco, G., 1992; Ribeiro, Seravalli, 2004) 
Como composto químico a água apresenta comportamentos bem diferenciados. Seu ponto de ebulição à $100^{\circ} \mathrm{C}$ é extremamente elevado e se deve a um agrupamento de moléculas mediante pontes de hidrogênio. O segundo aspecto a chamar a atenção é o aumento de volume da água durante o processo de solidificação como o gelo que se forma na superfície da água. Finalmente a água possui um calor específico consideravelmente alto, que tem demonstrado ser de importância extrema para o equilíbrio químico térmico tanto da terra como do corpo humano. Dessa forma, se explica o fato da terra poder sofrer trocas consideráveis de calor e frio sem que ela mesma sofra trocas importantes de temperatura. Por outro lado, pequenas quantidades de transpiração já permitem reduzir sensivelmente a temperatura corporal do ser humano.

A água na quantidade, localização e estrutura adequada é essencial para o processo vital, influencia na textura, na aparência, no sabor e na deterioração química e microbiológica dos alimentos. Quanto maior o teor de água de um alimento, maior é a sua sensibilidade à deterioração e é por isso que a maioria dos métodos de preservação de alimentos baseia-se na remoção da água pela secagem, na redução da mobilidade da água por congelamento ou, ainda, na adição de solutos.

A adição de sólidos à água resulta em alteração de suas propriedades e também do sólido adicionado. Em vista de suas propriedades a água interage fortemente com substâncias hidrofílicas, por meio de ligações iônicas, dipolo-dipolo ou covalentes, o que resulta em alterações na estrutura e mobilidade da água e na estrutura e reatividade das substâncias hidrofílicas.

A água presente nos alimentos encontra-se em 2 formas, ou seja, água livre e água ligada. A água ligada é definida como a água em contato com solutos e outros constituintes não aquosos, que exibe mobilidade reduzida e que não congela a $-40 \mathrm{C}$. Portanto, a água ligada não se comporta da mesma forma que a água pura. 0 teor de água livre varia com o tipo de alimento. Existem vários graus de ligação da água e, em função desse fato, a água ligada é subdividida em água constitucional, água vicinal e água de multicamadas. A água ligada está presente em quantidades muito pequenas no alimento (por exemplo, em batata, a quantidade de água ligada está em torno de $0,090 \mathrm{~g}$ de água/g de matéria seca), e não está disponível para o crescimento de microrganismos nem para reações enzimáticas.

Água constitucional: representa uma pequena fração da água presente em alimentos com alto teor de umidade. É a água ligada mais fortemente aos constituintes não aquosos do alimento, através de ligações iônicas.

Água vicinal: representa a próxima camada de água adjacente à água constitucional. Ocupa os sítios mais próximos da maioria dos grupos hidrofílicos presentes nos constituintes não aquosos.

Água de multicamadas: representa a água ligada em menor intensidade que a água vicinal. Seria a água ligada de forma mais fraca aos constituintes não aquosos do alimento, mas que ainda possui uma intensidade de ligação com os solutos que não lhe permite comportar-se como água pura.

A água livre presente no alimento é a água que apresenta as mesmas propriedades da água pura, que está disponível para o crescimento de microrganismos e para reações enzimáticas, mas que não flui livremente do alimento quando o mesmo é cortado.

O termo "capacidade de ligar água" é usado para descrever a habilidade de uma matriz de moléculas, normalmente macromoléculas, de aprisionar grandes quantidades de água e prevenir, assim, sua exsudação. Essa água não flui livremente do alimento, mas é facilmente retirada durante o processo de secagem e convertida em gelo durante o congelamento. Esse tipo de água constitui a principal fração da água presente nos alimentos e quaisquer alterações na sua quantidade ou forma de ligação com os sólidos afeta a qualidade do alimento. Por exemplo, quando a carne é submetida à cocção, as proteínas são desnaturadas, perdendo a capacidade de ligar água. Consequentemente, a carne perde massa e se torna mais dura.

A água se fixa aos alimentos por adsorção e por outras forças. Uma das mais significativas é muito provavelmente a pressão capilar, que conduz a uma ligação mais forte da água nos finos capilares dos alimentos. Dado que o diâmetro dos capilares nos alimentos (por exemplo, carne e batatas) é de aproximadamente $1 \mu$, tem-se que exercer uma pressão de aproximadamente 1,5 bar para superar a pressão capilar. A água fixada nos alimentos tem uma pressão de vapor p menor que a água livre (pressão 
de vapor $\mathrm{p}_{0}$ ). Quanto mais adsorvida está a água, menor será sua pressão de vapor. Para expressar a força da ligação da água se estabeleceu a equação $\mathbf{p} / \mathbf{p}_{\mathbf{0}}=\mathbf{a}_{\mathbf{w}}$ que se define como atividade de água $\left(\mathrm{a}_{\mathrm{w}}\right)$.

Já foi comprovado em experimentos de congelamento, que nem toda a água contida nos alimentos pode congelar. Isso se pode concluir a partir, dentre outras coisas da entalpia de fusão, da qual se pode obter o calor de cristalização liberado pelo gelo.

0 fato de que uma parte de água não se congela explica a maior ou menor força de fixação aos componentes dos alimentos, por exemplo, as proteínas. A reidratação parcialmente incompleta de alimentos desidratados nos leva a mesma conclusão. Neste caso é evidente que a excessiva extração de água leva o produto a uma troca em sua estrutura interior, de modo que este já não pode absorver a mesma quantidade de água que continha originalmente.

Os microrganismos também necessitam de um mínimo de conteúdo de água. Esta descoberta tem sido utilizada para a conservação de alimentos (hortaliças e carnes desidratadas).

Tabela 2. Limites de crescimento de alguns microrganismos

\begin{tabular}{|c|l|}
\hline \multicolumn{1}{|c|}{ Atividade de água } & \multicolumn{1}{c|}{ Tipo de microrganismo } \\
\hline $0,91-0,95$ & Bactérias comuns \\
\hline 0,88 & Leveduras comuns \\
\hline 0,80 & Bolores (mofos) comuns \\
\hline 0,75 & Bactérias halofílicas \\
\hline 0,70 & Bactérias osmofílicas \\
\hline 0,65 & Bolores (mofos) xerofílicos \\
\hline 0,60 & Leveduras osmofílicas \\
\hline (Fonte: Vasconcelos; Liberato; Morais, 2004)
\end{tabular}

\section{INTERAÇÕES DA ÁGUA COM OS ALIMENTOS}

Muitas propriedades importantes dos alimentos principalmente a sua suscetibilidade ao crescimento microbiano, se relacionam com o teor de água presente. Porém, não é a quantidade de água por si própria a determinante da estabilidade. 0 importante é a disponibilidade de água para os microrganismos, e não sua abundância. Deve-se levar em conta que o conteúdo de água e a atividade de água não são equiparáveis. Existem microrganismos que podem viver, por exemplo, em alimentos com conteúdo de água $0,3 \%$. No entanto, nesse caso devido à baixa ligação da água à matriz, as atividades de água poderiam ser da ordem de 0,8-0,9.

A tabela 2 mostra que a maioria dos microrganismos requerem altas atividades de água para viverem. As bactérias halofílicas (que se desenvolvem em concentrações elevadas de sais) são aquelas normalmente associadas a ambientes marinhos e com os peixes dessa procedência. Os bolores xerofílicos e leveduras osmofílicas são especialmente adaptados aos ambientes com baixa atividade de água. Suas células possuem concentrações extra-elevadas de solutos particulares a fim de não perderem água (por osmose) para a vizinhança. Nas bactérias, esses "solutos protetores" são usualmente os aminoácidos prolina ou ácido glutâmico e, nos fungos, são poliálcoois como glicerol ou ribitol. Esses fungos e leveduras podem oferecer sérios problemas para o armazenamento de alguns alimentos geralmente consideráveis estáveis, principalmente frutas secas. Felizmente, eles, até agora, não foram associados com a produção de micotoxinas, somente à deterioração física, que fica mais evidente.

0 crescimento microbiano não é o único fenômeno importante afetado pela atividade de água. As velocidades das reações enzimáticas e não enzimáticas são também acentuadamente afetadas pela atividade de água. As reações enzimáticas ocorrem em qualquer valor de atividade de água sendo predominantes em valores acima de 0,3. As enzimas participantes são as intrínsecas do alimento e também as externas provenientes, por exemplo, de microrganismos. As mais importantes reações enzimáticas são as de decomposição da gordura por lipases, fosfolipases e lipoxidases; as de escurecimento enzimático em frutas e vegetais, as peroxidases e as fenoloxidases.

Em baixos valores de atividade de água, a mais importante reação de deterioração é a oxidação lipídica que decorre da reação dos radicais livres com lipídeos insaturados causando o aparecimento de odores característicos de rancidez. 0 efeito da oxidação diminui com o aumento do teor de água. Por exemplo, a 
taxa de hidrólise enzimática de lipídeos, em alimentos como a carne, torna-se desconsiderável (isto é, mais ou menos $1 \%$ apenas da velocidade com que ocorre no valor mais alto de atividade de água) em valores de atividade de água abaixo de 0,4 .

As reações não enzimáticas (R. de Maillard), ocorrem em qualquer valor de atividade de água apresentando um máximo na faixa entre 0,4 e 0,6. A característica da reação é o escurecimento do produto e o aparecimento de flavor amargo.

Se um material contendo proteína e amido é seco a valores muito baixos, ocorrerá desnaturação irreversível destes materiais. A desnaturação é causada pela interação de sítios reativos, resultando em alterações de textura em alimentos ricos em proteína. 


\section{CAPÍTULO \\ 02 Carboidratos}

Os carboidratos estão amplamente distribuídos pela natureza. Englobam substâncias com estruturas e propriedades funcionais diversas. Pertencem a esse grupo substâncias como glicose, frutose e sacarose, responsáveis pelo sabor doce de vários alimentos, amido, principal fonte de reserva de alguns tecidos vegetais, e a celulose, o carboidrato mais abundante na natureza e principal componente de tecidos vegetais. Eles constituem a fonte de energia mais abundante e econômica para o homem. Alguns carboidratos, como celulose e hemicelulose, não são fontes de energia, mas são fontes de fibras dietéticas.

\section{FOTOSSÍNTESE}

A produção de carboidratos ocorre nas plantas verdes pelo processo denominado de fotossíntese. A planta contém o pigmento verde clorofila, que catalisa a biossíntese de carboidratos, a partir de dióxido de carbono e água. A reação é termodinamicamente desfavorável, mas ocorre porque a energia necessária é fornecida pela luz solar. Enquanto as plantas sintetizam carboidratos a partir de $\mathrm{CO}_{2}$ e água, os organismos

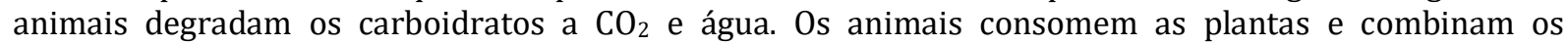
carboidratos com o oxigênio do ar e, assim, executam a reação inversa à fotossíntese, a respiração. A oxidação de carboidratos oferece ao animal a energia necessária para manter os processos vitais e regenera $\mathrm{o}_{\mathrm{CO}_{2}}$ que a planta utilizará na fotossíntese. Portanto, a fotossíntese é o processo pelo qual a energia luminosa é transformada em energia química. A equação geral da fotossíntese é:

$$
6 \mathrm{CO}_{2}+6 \mathrm{H}_{2} \mathrm{O} \rightarrow \mathrm{C}_{6} \mathrm{H}_{12} \mathrm{O}_{6}+6 \mathrm{O}_{2} \quad \Delta \mathrm{G}^{0^{\prime}}=+2.870{\mathrm{~kJ} . \mathrm{mol}^{-1}}^{-1}
$$

Como quase todos os organismos que não fazem fotossíntese dependem da energia química presente nos compostos produzidos pelos seres fotossintetizadores, pode-se dizer que toda a energia consumida pelos sistemas biológicos deriva primariamente da energia solar. A equação da fotossíntese é exatamente o inverso da equação de oxidação total da glicose que ocorre em todas as células aeróbias:

$$
\mathrm{C}_{6} \mathrm{H}_{12} \mathrm{O}_{6}+6 \mathrm{O}_{2} \longrightarrow 6 \mathrm{CO}_{2}+6 \mathrm{H}_{2} \mathrm{O} \quad \Delta \mathrm{G}^{0^{\prime}}=-2.870{\mathrm{~kJ} . \mathrm{mol}^{-1}}^{-1}
$$

Porém é incorreto afirmar que a fotossíntese é um processo inverso ao da respiração, definida comumente como a oxidação da glicose a $\mathrm{CO}_{2}$ e $\mathrm{H}_{2} \mathrm{O}$.

Inicialmente, em função do processo de fotossíntese, eram denominadas de carboidratos somente as substancias que apresentavam a fórmula empírica geral da maioria dos hidratos de carbono $\left(\mathrm{C}_{\mathrm{X}}\left(\mathrm{H}_{2} \mathrm{O}\right)_{\mathrm{x}}\right)$, com o desenvolvimento dos métodos químicos verificou-se que esta generalização era incorreta.

São definidos como carboidratos os polihidroxialdeídos, as polihidroxicetonas, os polihidroxiálcoois, os polihidroxiácidos, seus derivados e, polímeros desses compostos unidos por ligações hemiacetálicas.

Os carboidratos classificam-se em: monossacarídeos, dissacarídeos, oligossacarídeos e polissacarídeos. Quando a palavra "carboidrato" foi inventada, referia-se originalmente aos compostos com fórmula geral $\mathrm{C}_{\mathrm{n}}\left(\mathrm{H}_{2} \mathrm{O}\right)_{\mathrm{n}}$. No entanto, somente os açúcares simples, ou monossacarídeos, encaixam-se exatamente nessa fórmula. 
Os monossacarídeos são os menores e mais simples carboidratos, que, se hidrolisados a compostos de menor peso molecular, não serão mais carboidratos, correspondem a menor unidade estrutural de um carboidrato. Esses compostos apresentam um dos seguintes grupos funcionais: poli-hidroxialdeído, polihidroxicetona, polihidroxiácido e polihidroxiálcool.

$$
\begin{aligned}
& \text { Polihidroxialdeídos (aldoses): } \mathrm{HOCH}_{2}-(\mathrm{CHOH})_{\mathrm{N}}-\mathrm{CHO} \\
& \text { Polihidroxicetonas (cetoses): } \mathrm{HOCH}_{2}-(\mathrm{C}=\mathrm{O})-(\mathrm{CHOH})_{\mathrm{N}-1}-\mathrm{CHO} \\
& \text { Polihidroxiálcoois: } \mathrm{HOCH}_{2}-(\mathrm{CHOH})_{\mathrm{N}}-\mathrm{CH}_{2} \mathrm{OH} \\
& \text { Polihidroxiácidos: } \mathrm{HOCH}_{2}-(\mathrm{CHOH})_{\mathrm{N}}-\mathrm{COOH}
\end{aligned}
$$

O menor monossacarídeo apresenta 3 carbonos na molécula. Em alimentos apresentam normalmente 6 carbonos e menos frequentemente 5 carbonos.

Os outros tipos de carboidratos baseiam-se em unidades de monossacarídeos e apresentam fórmulas gerais ligeiramente diferentes. Os dissacarídeos, como os polissacarídeos, não atravessam a parede intestinal. Só são aproveitados como fonte de energia se previamente hidrolisados a monossacarídeos, que passam rapidamente do trato intestinal à corrente sanguínea. Os oligossacarídeos e os polissacarídeos não hidrolisados passam ao largo do intestino delgado até o intestino grosso, onde exercem um efeito benéfico (fibra). Os oligossacarídeos podem ser atacados pela microflora intestinal gerando produtos metabólicos como os ácidos acético e láctico. Em grandes quantidades têm efeito laxante podendo causar diarreia.

Os carboidratos proporcionam também texturas desejáveis, palatabilidade agradável, poder edulcorante. Dos polissacarídeos do mundo biológico, o homem só digere amido, glicogênio e certas dextranas. 0 glicogênio é semelhante à amilopectina do amido, porém mais ramificado. Constitui a reserva energética dos animais, armazenando-se principalmente no fígado e, em menor quantidade, no músculo. 0 amido e o glicogênio começam a ser hidrolisados na boca pela ação da $\alpha$ - amilase contida na saliva. Ela produz um fragmento de seis unidades de glicose que são também hidrolisados produzindo maltose, maltotreose e maltotetrose. 0 alimento vai para o estômago e, no duodeno, ocorre uma hidrólise. Lá, $\beta$ - amilase ataca o amido e os fragmentos da ação da $\alpha$ - amilase, liberando unidades de maltose. A maltose é hidrolisada à glicose pela enzima maltase e é transportada à corrente sanguínea.

Os polissacarídeos diferentes do amido e glicogênio não são hidrolisados pelas enzimas gastrointestinais passando ao intestino grosso, mais ou menos intactos. São eles: celulose, hemicelulose e pectina das paredes vegetais. Eles facilitam a passagem do bolo fecal através do sistema digestivo. A eliminação rápida de produtos não absorvidos evita o aparecimento de condições propícias ao desenvolvimento de câncer, ajudam a diminuir o colesterol do sangue e retardam o aparecimento de arterioscleroses. Carboidratos digeríveis proporcionam aproximadamente $4 \mathrm{Kcal} / \mathrm{g}$, energia equivalente à proporcionada por $1 \mathrm{~g}$ de proteína e inferior às $9 \mathrm{Kcal} / \mathrm{g}$ dos lipídeos.

\section{Dissacarídeos}

\begin{tabular}{|l|l|l|}
\multicolumn{1}{|c|}{ Açúcar } & \multicolumn{1}{c|}{ Fonte } & \multicolumn{1}{c|}{ Significado Clínico } \\
\hline Maltose & $\begin{array}{l}\text { Digerido pela amilase ou hidrólise do amido. Cereais } \\
\text { e malte em germinação. }\end{array}$ & $\begin{array}{l}\text { Na deficiência de lactase. A má } \\
\text { absorção provoca diarreia e } \\
\text { flatulência. }\end{array}$ \\
\hline Lactose & Leite. Pode ocorrer na urina durante a gravidez. & $\begin{array}{l}\text { Na deficiência da sacarase. A má } \\
\text { absorção provoca diarreia e } \\
\text { flatulência. }\end{array}$ \\
\hline Sacarose & $\begin{array}{l}\text { Açúcar de cana e beterraba. Sorgo. Abacaxi. Raiz de } \\
\text { cenoura. }\end{array}$ & \\
\hline Trealose ${ }^{1}$ & $\begin{array}{l}\text { Fungos e leveduras. Principal açúcar da hemolinfa } \\
\text { de insetos. }\end{array}$ & \\
\hline
\end{tabular}

$\alpha$-D-glicopiranosil-(1 $\rightarrow 1)-\alpha-\mathrm{D}-$ glicopiranósido. 
Pentoses de importância fisiológica

\begin{tabular}{|c|c|c|c|}
\hline Açúcar & Fonte & Importância bioquímica & $\begin{array}{l}\text { Significado } \\
\text { clínico }\end{array}$ \\
\hline D-Ribose & Ácidos nucleicos & $\begin{array}{l}\text { Elementos estruturais dos ácidos nucleicos } \\
\text { e coenzimas, p. ex., ATP, NAD, NADP, } \\
\text { flavoproteínas. As ribose-fosfatos são } \\
\text { intermediárias da via das pentoses-fosfato. }\end{array}$ & \\
\hline D-Ribulose & $\begin{array}{l}\text { Formada nos processos } \\
\text { metabólicos }\end{array}$ & $\begin{array}{l}\text { A ribulose-fosfato é um intermediário da } \\
\text { via das pentoses-fosfato. }\end{array}$ & \\
\hline D-Arabinose & $\begin{array}{l}\text { Goma arábica. Gomas da } \\
\text { ameixa e da cereja. }\end{array}$ & Constituinte das glicoproteínas. & \\
\hline D-Xilose & $\begin{array}{l}\text { Gomas de madeiras, } \\
\text { proteoglicanas, } \\
\text { glicosaminoglicanas. }\end{array}$ & Constituinte de glicoproteínas. & \\
\hline D-Lixose & Músculo cardíaco. & $\begin{array}{l}\text { Constituinte de uma lixoflavina isolada do } \\
\text { músculo cardíaco humano. }\end{array}$ & \\
\hline L-Xilulose & \multicolumn{2}{|c|}{ Intermediário da via do ácido urônico. } & $\begin{array}{l}\text { Encontrada na } \\
\text { urina }\end{array}$ \\
\hline
\end{tabular}

Hexoses de importância fisiológica

\begin{tabular}{|c|l|l|l|}
\hline \multicolumn{2}{|c|}{ Açúcar } & \multicolumn{2}{|c|}{ Fonte } \\
\hline D-Glicose & $\begin{array}{l}\text { Sucos de frutas. Hidrólise } \\
\text { do amido, do açúcar de } \\
\text { cana, da maltose e da } \\
\text { lactose. }\end{array}$ & $\begin{array}{l}\text { É o açúcar do organismo. 0 } \\
\text { açúcar transportado pelo } \\
\text { sangue, e o principal usado } \\
\text { pelos tecidos. }\end{array}$ & $\begin{array}{l}\text { Presente na urina (glicosúria) no } \\
\text { diabetes mellitus devido ao } \\
\text { aumento da glicose sanguínea } \\
\text { (hiperglicemia). }\end{array}$ \\
\hline D-Frutose & $\begin{array}{l}\text { Sucos de frutas. Mel. } \\
\text { Hidrólise do açúcar de cana } \\
\text { e da inulina (da alcachofra } \\
\text { de Jerusalém). }\end{array}$ & $\begin{array}{l}\text { Pode ser transformada em } \\
\text { glicose no fígado e assim usada } \\
\text { no organismo. }\end{array}$ & $\begin{array}{l}\text { Intolerância hereditária a frutose } \\
\text { conduz ao acúmulo de frutose e } \\
\text { hipoglicemia. }\end{array}$ \\
\hline D-Galactose & Hidrólise da lactose. & $\begin{array}{l}\text { Pode ser transformada em } \\
\text { glicose no fígado e } \\
\text { metabolizada. Sintetizada na } \\
\text { glândula mamária para formar } \\
\text { a lactose do leite. }\end{array}$ & $\begin{array}{l}\text { A falha na metabolização conduz } \\
\text { à galactosemia e à catarata. }\end{array}$ \\
\hline
\end{tabular}

\begin{tabular}{|c|c|c|c|}
\hline Carboidratos & Fontes & $\begin{array}{l}\text { Prod. finais } \\
\text { da digestão }\end{array}$ & Observação \\
\hline \multicolumn{4}{|c|}{ Polissacarídeos indigeríveis } \\
\hline \multirow{2}{*}{$\begin{array}{l}\text { 1. Celulose } \\
\text { 2. Hemicelulose }\end{array}$} & \multirow{2}{*}{$\begin{array}{l}\text { Talos e folhas de vegetais. } \\
\text { Camada externa de } \\
\text { revestimento de grãos. }\end{array}$} & - & \\
\hline & & - & \\
\hline \multirow{2}{*}{$\begin{array}{l}\text { 3. Pectinas } \\
\text { 4. Gomas e } \\
\text { mucilagens }\end{array}$} & \multirow{2}{*}{$\begin{array}{l}\text { Frutas Sementes e secreções } \\
\text { vegetais }\end{array}$} & - & \\
\hline & & - & \\
\hline $\begin{array}{l}\text { 5. Subst. derivadas } \\
\text { de algas }\end{array}$ & Plantas marinhas e algas & - & \\
\hline \multicolumn{4}{|c|}{ Polissacarídeos parcialmente digeríveis } \\
\hline 1. Inulina & $\begin{array}{l}\text { Alcachofra, cebola, alho, } \\
\text { cogumelos. }\end{array}$ & Frutose & \\
\hline 2. Galactógenos & Escargot & Galactose & \\
\hline 3. Manoses & Leguminosas & Manose & \\
\hline 4.Rafinose & $\begin{array}{l}\text { Açúcar de beterraba, feijão, } \\
\text { feijão branco, lentilhas }\end{array}$ & $\begin{array}{c}\text { Glicose, frutose e } \\
\text { galactose }\end{array}$ & \\
\hline 5. Estaquiose & Feijão & Pentoses & \\
\hline 6.Pentosanas & Frutas e gomas & - & \\
\hline
\end{tabular}




\begin{tabular}{|c|c|c|c|}
\hline Carboidratos & Fontes & $\begin{array}{l}\text { Prod. finais } \\
\text { da digestão }\end{array}$ & Observação \\
\hline \multicolumn{4}{|c|}{ Polissacarídeos digeríveis } \\
\hline 1. Amido e dextrinas & $\begin{array}{l}\text { Grão; vegetais (especialmente } \\
\text { leguminosas e tubérculos) }\end{array}$ & Glicose & \\
\hline 2. Glicogênio & $\begin{array}{l}\text { Produtos de carne e frutos do } \\
\text { mar. }\end{array}$ & Glicose & \\
\hline \multicolumn{4}{|c|}{ Dissacarídeos e Oligossacarídeos } \\
\hline 1. Sacarose & $\begin{array}{l}\text { Açúcar de cana e beterraba, } \\
\text { melaço e xarope de bordo }\end{array}$ & Glicose e Frutose & \\
\hline 2. Lactose & Leite e derivados & $\begin{array}{l}\text { Glicose e } \\
\text { Galactose }\end{array}$ & \\
\hline 3. Lactulose & Produtos sintéticos & $\begin{array}{c}\text { Não } \\
\text { metabolizados }\end{array}$ & $\begin{array}{l}\text { Não aparece em alimentos; é } \\
\text { sintético, não digerível e é usado } \\
\text { como laxativo. }\end{array}$ \\
\hline $\begin{array}{l}\text { 4. Maltose e } \\
\text { Maltotriose }\end{array}$ & $\begin{array}{l}\text { Produtos do Malte; alguns } \\
\text { cereais matinais }\end{array}$ & Glicose & \\
\hline 5. Trealose & Cogumelos, insetos, leveduras & Glicose & \\
\hline \multicolumn{4}{|l|}{ Monossacarídeos } \\
\hline 1. Glicose Sorbitol* & $\begin{array}{l}\text { Frutas, mel, xarope de milho } \\
\text { Frutas, vegetais e produtos } \\
\text { dietéticos }\end{array}$ & Glicose & \multirow{2}{*}{$\begin{array}{l}\text { Em frutas e vegetais, as } \\
\text { concentrações de glicose e frutose } \\
\text { dependem do amadurecimento da } \\
\text { espécie e do estado de preservação. }\end{array}$} \\
\hline 2. Frutose & Frutas e mel & Frutose & \\
\hline 3.Galactose & - & Galactose & \multirow[b]{2}{*}{$\begin{array}{l}\text { Esses monossacarídeos não ocorrem } \\
\text { na forma livre no alimento. }\end{array}$} \\
\hline 4.Manose Manitol* & $\begin{array}{l}\text { Abacaxi, azeitona, aspargos, } \\
\text { batata-doce, cenoura e } \\
\text { produtos diet }\end{array}$ & Manose & \\
\hline \multicolumn{4}{|l|}{ Pentoses } \\
\hline 1. Ribose & - & Ribose & \multirow{3}{*}{$\begin{array}{l}\text { Ribose, Xilose e Arabinose não } \\
\text { ocorrem na forma livre nos } \\
\text { alimentos. São derivados de } \\
\text { pentosanas de frutas, dos ácidos } \\
\text { nucleicos de produtos da carne e } \\
\text { frutos do mar. }\end{array}$} \\
\hline 2. Xilose Xilitol* & $\begin{array}{l}\text { Frutas, vegetais, cereais, } \\
\text { cogumelos, frutos do mar, } \\
\text { gomas de mascar dietéticas e } \\
\text { outros produtos dietéticos }\end{array}$ & Xilose & \\
\hline 3.Arabinose & - & Arabinose & \\
\hline \multicolumn{4}{|c|}{ Derivados de Carboidratos } \\
\hline 1. Álcool Etílico & Licores fermentados & \multirow{3}{*}{$\begin{array}{l}\text { Absorvidos nessa } \\
\text { forma }\end{array}$} & \multirow{3}{*}{$\begin{array}{l}\text { São produtos da quebra natural ou } \\
\text { induzida de carboidratos. }\end{array}$} \\
\hline 2. Ácido Láctico & Leite e produtos lácteos & & \\
\hline 3. Ácido Málico & Frutas & & \\
\hline
\end{tabular}

(Fonte: Salinas, 2002; Liberato; Oliveira, 2013)

Os carboidratos têm função estrutural por causa do DNA e RNA. Têm função relacionada aos receptores de membranas, que são de natureza glicoproteicas. Sua fórmula geral é $\mathrm{Cn}\left(\mathrm{H}_{2} \mathrm{O}\right)_{n}=\mathrm{C}_{n} \mathrm{H}_{2 n} \mathrm{O}_{n}$.

\section{MONOSSACARÍDEOS, DISSACARÍDEOS, OLIGOSSACARÍDEOS E POLISSACARÍDEOS}

Os monossacarídeos são incapazes de serem hidrolisados a uma forma mais simples. Os dissacarídeos podem ser hidrolisados, dando duas moléculas de monossacarídeos. Os carboidratos conhecidos como monossacarídeos são as Hexoses (Açúcares com 6C) e as Pentoses (açúcares com 5C). Os oligossacarídeos produzem de 3 a 10 unidades de monossacarídeos, enquanto os polissacarídeos produzem de 10 a 10.000 ou mais unidades de monossacarídeos.

\section{MONOSSACARÍDEOS}

Os monossacarídeos podem ser polihidroxialdeídos (aldose) ou polihidroxicetonas (cetose). Os monossacarídeos mais simples possuem três átomos de carbono. São as trioses. 0 gliceraldeído é a aldose com três carbonos (uma aldotriose), e a diidroxiacetona é a cetose com três carbonos (uma cetotriose). Aldoses que possuem 4, 5, 6, e 7 átomos de carbono são chamadas aldotetroses, aldopentoses, aldohexoses e aldoheptoses, respectivamente e as cetoses correspondentes são cetotetroses, cetopentoses, cetohexoses e cetoheptoses. Os açúcares com seis carbonos são os mais abundantes na natureza, porém dois açúcares com cinco carbonos, a ribose e a desoxirribose, estão presentes nas estruturas de RNA e DNA, 
respectivamente. Açúcares com 4 e 7 carbonos têm importantes papéis na fotossíntese e em vias metabólicas.

Algumas moléculas não podem ser superpostas em suas imagens especulares. Essas imagens são isômeros ópticos (estereoisômeros) umas das outras. Um átomo de carbono quiral (assimétrico) é o objeto da isomeria óptica. 0 carboidrato mais simples, que contém um carbono quiral, é o gliceraldeído, podendo existir em duas formas isoméricas que são imagens especulares uma da outra. Elas são designadas Dgliceraldeído e L-gliceraldeído. Os estereoisômeros de imagem especular são também chamados enantiômeros.

Os dois enantiômeros do gliceraldeído são os únicos estereoisômeros possíveis nos açúcares de três carbonos, mas as possibilidades aumentam conforme as estruturas possuam mais átomos de carbono. Para mostrar as estruturas das moléculas resultantes, é preciso usar-se a perspectiva bidimensional da estrutura molecular, denominada método de projeção de Fischer. Nesse método, as ligações escritas "verticalmente" no papel, que é bidimensional, representam as ligações direcionadas para trás do papel, se forem consideradas três dimensões, ao passo que as ligações escritas "horizontalmente" representam as ligações direcionadas para a frente do papel. A designação da configuração como L ou D depende do arranjo do carbono quiral com número mais alto.

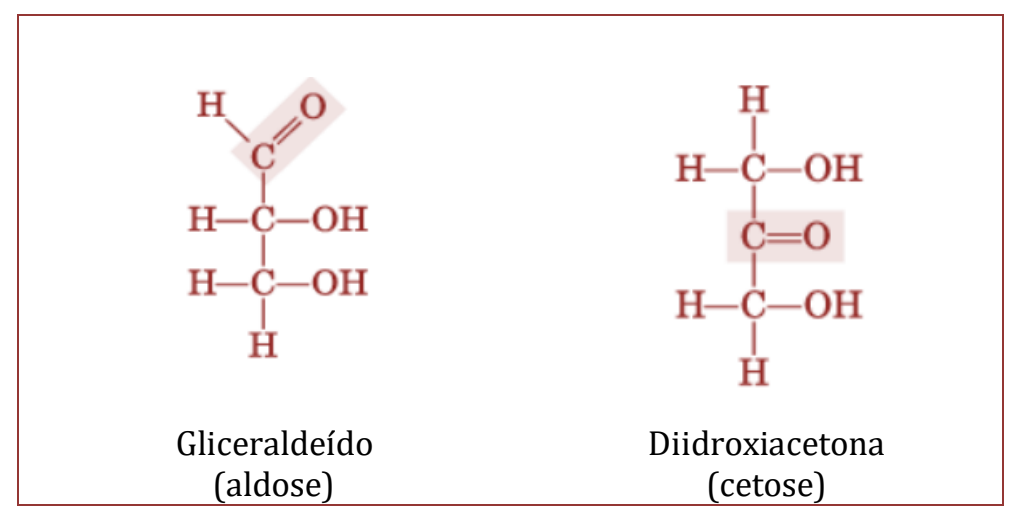

Estereoisômeros de imagens não-especulares e que não podem ser sobrepostos são chamados diastereoisômeros. São chamados epímeros os diasteroisômeros que diferem uns dos outros na configuração em somente um C quiral. Ex: D - eritreose e D - treose; $\alpha$ - D - galactose e $\alpha$ - D - glicose e $\alpha$ - D - Manose. A maioria dos açúcares importantes encontrados na natureza possui a configuração D, baseada no D-gliceraldeído.

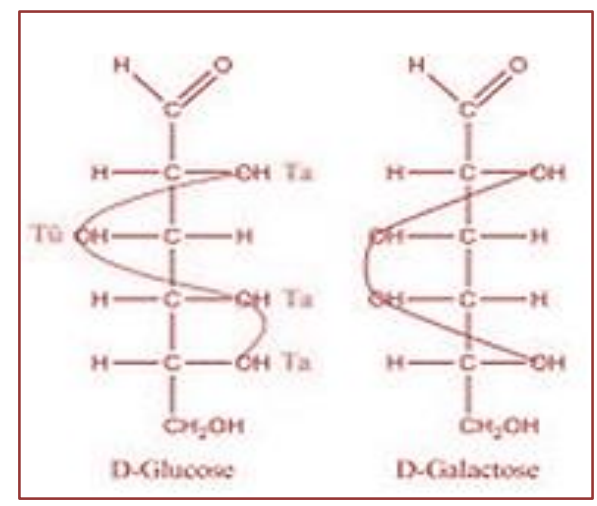

Wikipédia.org

Açúcares especialmente os que possuem cinco ou seis carbonos existem normalmente como moléculas cíclicas ao invés das cadeias abertas. A ciclização é resultante da interação entre os grupos funcionais em carbonos distantes, como C-1 e C-5, para formar um hemiacetal cíclico (em aldohexoses). Outra possibilidade é a formação de um hemicetal cíclico (em cetohexoses) através da interação entre C-2 e C-5. 
Em ambos os casos, o carbono carbonílico torna-se um novo centro quiral chamado carbono anomérico. 0 açúcar cíclico pode assumir qualquer uma das duas formas diferentes $\alpha$ e $\beta$, e são chamados anômeros um do outro. Na realidade a carbonila dos monossacarídeos não é encontrada como tal, mas combinada com uma das hidroxilas da mesma molécula em uma ligação hemiacetálica, onde o grupo carbonila adiciona água ou álcoois simples para formar hemiacetais (Fonte: Lajolo; Mercadante; 2018).

Representação de uma ligação hemiacetálica

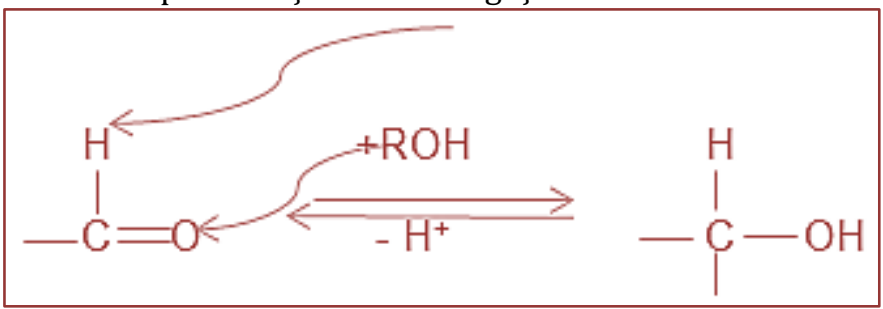

(Fonte: Ribeiro; Seravalli, 2004)

De forma semelhante, grupos hidroxilas do monossacarídeo adicionam-se ao grupo carbonila para formar hemiacetais internos cíclicos. A formação do acetal converte o carbono da carbonila em um carbono assimétrico, formando, assim mais 2 isômeros. Estes isômeros são tão importantes na série de carboidratos que recebem um nome especial, anômeros. 0 carbono do grupo carbonila é denominado de carbono anomérico.

O grupo hidroxila formado devido à ligação hemiacetálica é denominado de grupo hidroxila anomérico. Este grupo é extremamente reativo e confere ao monossacarídeo a propriedade de ser um agente redutor em reações de óxido-redução, é a única hidroxila da molécula proveniente de um grupo carbonila. Se o grupo hidroxila anomérico é formado do lado direito da molécula, denomina-se o monossacarídeo de $\alpha$ e, se for do lado esquerdo de $\beta$.

Além das fórmulas de projeção de Fischer, existem também as fórmulas de projeção de Haworth que representam mais precisamente o formato nas moléculas cítricas com cinco ou seis membros. 0 anel de cinco membros é chamado furanose, e o de seis, piranose.

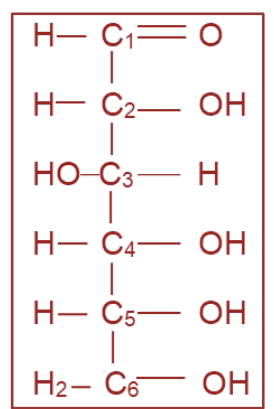

D-Glucose (Está presente em frutas, mel, milho e raízes). É armazenada no fígado e nos músculos, como o glicogênio.

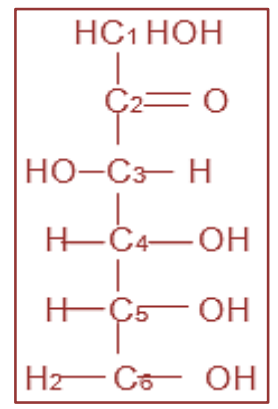

D- Frutose (Levulose ou açúcar da fruta. Está presente em mel e frutas).

Galactose: Não é encontrada na forma livre na natureza. É produzida a partir da lactose (açúcar do leite) por hidrólise no sistema digestório. 


\section{REAÇõES DOS MONOSSACARÍDEOS}

\section{REAÇÕES DE OXIDORREDUÇÃO}

Essas reações dos açúcares são fundamentais na bioquímica. A oxidação dos açúcares é responsável pelo fornecimento de energia para que os processos vitais dos organismos sejam realizados.

\section{REAÇÕES DE ESTERIFICAÇÃO}

Os grupos hidroxila dos açúcares podem reagir com ácidos e derivados para formar ésteres. Os ésteres de fosfato são muito importantes por serem intermediários na degradação de carboidratos para fornecer energia.

\section{POLIIDROXIÁLCOOIS}

O grupo carbonila de uma aldose ou cetose pode ser reduzido a um poliálcool mediante a presença de um grupo redutor . Estes compostos são chamados itóis. Através dessa reação, é possível obter sorbitol a partir da redução da glicose, ou ribitol a partir da ribose ou manitol a partir da manose. Muitos desses compostos são comuns em tecidos vegetais, como por exemplo, o sorbitol é encontrado em pêras, maçãs, morangos e pêssegos.

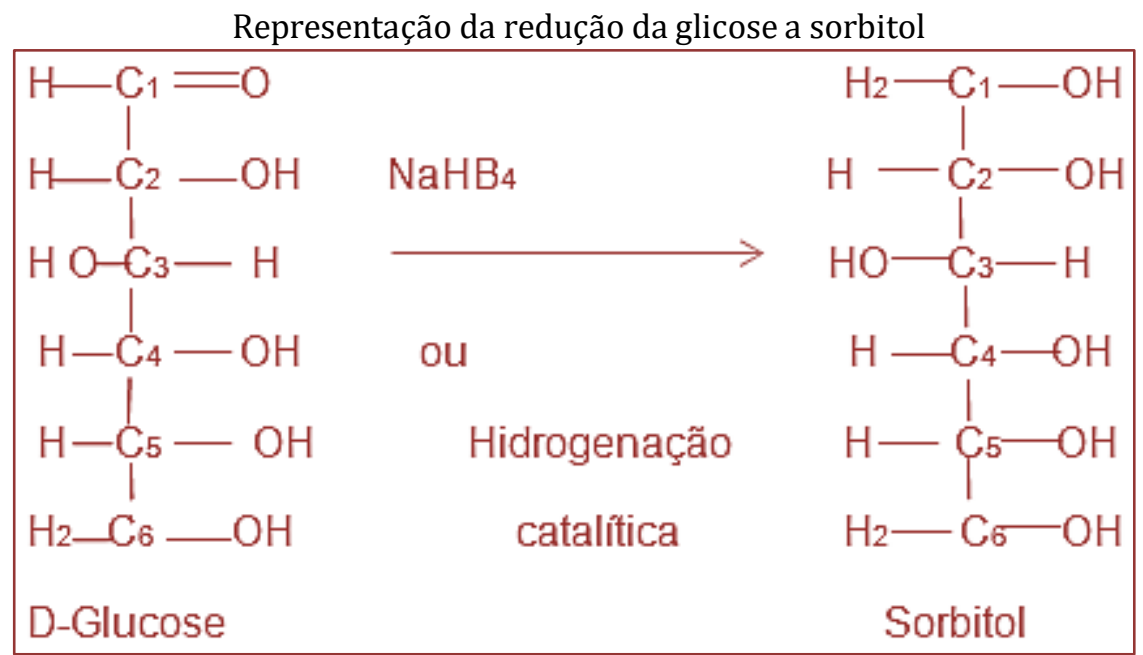

(Fonte: Ribeiro; Seravalli, 2004)

\section{POLIHIDROXIÁCIDOS}

Os polihidroxialdeídos e polihidroxicetonas possuem grupos facilmente oxidáveis e na presença de agentes oxidantes oxidam-se a poliidroxiácidos.

\section{FORMACC̃̃O DE GLICOSÍDEOS}

Ocorre a formação de glicosídeos quando um grupo hidroxila de açúcar ligado a um carbono anomérico reage com outra hidroxila formando uma ligação glicosídica. Essa ligação não é um éter, pois os glicosídeos podem ser hidrolisados aos alcoóis originais. As ligações glicosídicas entre monossacarídeos são a base para a formação de dissacarídeos, oligossacarídeos e polissacarídeos. Diferentes formas estereoquímicas são possíveis em ligações glicosídicas, com importantes consequências para a função das substâncias assim formadas.

\section{DISSACARÍDEOS}

São formados pela união de dois monossacarídeos por ligações glicosídicas. Os mais importantes são: sacarose, lactose e maltose. A sacarose é formada por $\alpha-D$ - Glicose $+\alpha-D$ - Frutose. É o açúcar de uso 
comum. Está presente na cana de açúcar, açúcar de beterraba, melaço, xarope de bordo, xarope de milho, açúcar de bordo, frutas, vegetais e mel. A lactose, o açúcar presente no leite, é um dissacarídeo formado por $\beta$ - D- lactose e D- glicose. A galactose é um epímero C-4 da glicose. A maltose é um dissacarídeo obtido da hidrólise do amido, consistindo em dois resíduos de D-glicose. A levedura, especialmente a da cerveja, contém enzimas que hidrolisam o amido no broto da cevada (malte), primeiro em maltose e depois em glicose, que é fermentada na preparação da cerveja. glicose + frutose. Esta mistura se chama açúcar invertido (pois a enzima Sacarose $\Rightarrow \quad$ envolvida é a invertase) e causa cárie dentária. Ao contrário de hiperatividade, o consumo de carboidrato aumenta a produção de serotonina que traz um efeito sedativo ao sistema nervoso.

Açúcar do malte. Não é encontrado livre na natureza. É produzida durante a digestão, por enzimas que quebram grandes moléculas de amido em fragmentos de dissacarídeos, que podem ser quebrados em duas moléculas de glicose para facilitar a absorção. Isto ocorre na natureza. Quando a semente de um grão de cereal brota, suas enzimas convertem o grão em maltose. Ex.1: Malte da cevada usado como adoçante. Ex.2: Fabricação da cerveja: o amido é hidrolisado pela diástase, uma enzima obtida de grãos germinantes.

Açúcar do leite. Não existe em vegetais. Está limitada quase que exclusivamente às glândulas mamárias de animais lactentes. Por hidrólise dá: galactose + glicose. Problemas com esse açúcar: 1 - Pessoas com ausência da enzima lactase, não fazem uma hidrólise eficiente. 2 - Crianças pequenas nascidas sem a enzima do fígado que converte galactose em glicose.

\section{POLIHIDROXIÁLCOOIS OU POLIÁLCOOIS}

Os polihidroxiálcoois ou poliálcoois inibem uma elevação rápida de açúcar no sangue.

Sacarose $\Rightarrow$ forma alcoólica: SORBITOL

Maltose $\Rightarrow$ forma alcoólica: MANITOL

Lactose $\Rightarrow$ forma alcoólica: XILITOL
São usados em produtos para pessoas incapazes de tolerar grandes ingestões de açúcar, pois são absorvidos mais lentamente no trato digestório e, portanto, inibem uma elevação rápida do açúcar no sangue.

SORBITOL: É naturalmente encontrado em frutas. Tem poder adoçante igual ao da glicose. É bem absorvido e tem o mesmo valor energético da glicose.

MANITOL: Existe nas frutas, é precariamente digerido, produz metade das calorias da glicose, por grama.

XILITOL: Absorvido apenas 1/5 tão rápido quanto a glicose. É usado em gomas de mascar sem açúcar porque as bactérias cariogênicas são incapazes de usá-lo como substrato.

Figura 1: Moléculas de Dissacarídeos

Sacarose Lactose 


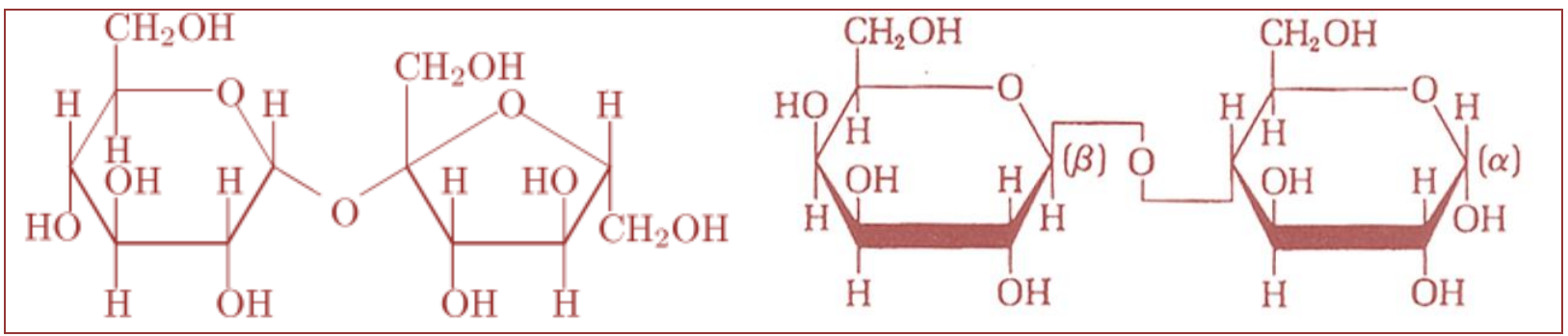

\section{ADOÇANTES ALTERNATIVOS}

São mais doces que os açúcares naturais. São digeridos ou absorvidos. Não têm valor nutritivo.

\section{HIPERTEXTO}

\section{MEL DE ABELHAS}

0 néctar da flor que contém sacarose é levado pela abelha para a colmeia. No favo, a abelha envolve o néctar com a enzima invertase que hidrolisa a maioria da sacarose em glicose e frutose. Após várias horas de evaporação, o mel amadurecido e concentrado é armazenado em células seladas. A doçura do mel varia com a concentração dos açúcares e grau de cristalização. Vitaminas e minerais aparecem como quantidades traços. A absorção entre açúcar e mel é quase igual. As diferenças entre mel e açúcar de mesa estão no fato de o mel conter, além de maior teor de frutose, outros componentes minoritários, como vitaminas, compostos fenólicos, flavonoides, minerais, entre outros. A frutose no sangue é principalmente convertida em glicogênio no fígado, um processo que não precisa de insulina. Porém, o alto conteúdo de glicose faz do mel um alimento que deve ser controlado para diabéticos, não insulino-dependentes (Fonte: Liberato; Morais, 2016).

\section{OLIGOSSACARÍDEOS}

Alguns autores incluem na definição de oligossacarídeos os dissacarídeos. Para eles, são polímeros contendo de 2 a 10 unidades de monossacarídeos unidos por ligações hemiacetálicas, que nesse caso são chamadas de ligações glicosídicas. Os mais importantes são os dissacarídeos, que podem ser homogêneos ou heterogêneos em função de sua composição monomérica.

Na polimerização de $n$ moléculas de monossacarídeos são liberadas n-1 moléculas de água, obtidas a partir da condensação do grupo hidroxila anomérico de um monossacarídeo com uma das hidroxilas da unidade adjacente. 0 radical produzido pela perda do grupo hidroxila anomérico denomina-se de glicosil.

A hidroxila anomérica confere propriedades redutoras ao monossacarídeo, reduzindo principalmente íons metálicos como cobre e prata e se oxidando a ácido carboxílico. Esses carboidratos são denominados de redutores devido à sua habilidade de reduzir íons, como prata ou cobre. Na formação de um dissacarídeo, sempre uma das hidroxilas está envolvida na ligação glicosídica, mais reativa, (radical glicosil). Se nessa formação a outra hidroxila anomérica estiver livre, esse dissacarídeo é redutor. Porém se ela estiver envolvida na ligação, o dissacarídeo não terá nenhuma hidroxila anomérica livre e, portanto, não será um agente redutor. A maioria dos dissacarídeos encontrados em alimentos são redutores, a principal exceção é a sacarose. Os trissacarídeos também ocorrem em alimentos e podem ser homogêneos, heterogêneos, redutores ou não redutores. Os tetrassacarídeos são menos frequentes em alimentos, sendo o mais comum, a estaquiose, que é não redutora. Dentre os principais oligossacarídeos merece especial atenção dos químicos de alimentos os derivados da sacarose que contêm galactose como a rafinose e a estaquiose, que são os mais conhecidos. Eles estão presentes em sementes de leguminosas como ervilhas e feijões e são responsáveis por problemas particulares no uso da soja como alimento. Esses açúcares não são hidrolisados nem absorvidos por nosso sistema digestório e, dessa forma, refeições contendo uma grande quantidade de feijão, por exemplo tornam-se um banquete para bactérias do intestino grosso, como a Escherichia coli. Elas produzem grandes quantidades de hidrogênio e de dióxido de carbono como subprodutos do seu metabolismo dos açúcares e certos desconfortos, como flatulência, surgem como consequência. 0 mesmo ocorre com a lactose presente no leite consumido por indivíduos que não produzem a enzima lactase no intestino delgado. 


\section{PROPRIEDADES FUNCIONAIS DE MONO E OLIGOSSACARÍDEOS EM ALIMENTOS}

Os mono e dissacarídeos conferem aos alimentos, nos quais estão naturalmente presentes ou são adicionados, diferentes características em função de sua estrutura e concentração, e das condições do alimento, tais como: teor de água, pH, etc. Esses compostos contribuem para o valor nutricional do alimento, fornecem calorias, podem ser umectantes, plastificantes, texturizantes, fortalecedores de sabor e adoçantes.

\section{UMECTÂNCIA}

Como os carboidratos ligam água do alimento, eles são capazes de controlar a atividade de água do mesmo. Essa habilidade de ligar água e controlar a atividade de água do alimento é uma de suas mais importantes propriedades funcionais. A capacidade de ligar água é denominada de umectância. Dependendo do produto, pode ser desejável limitar a entrada de água no alimento ou controlar a saída. Esse é o método usado na produção de doces, geleias, etc., para reduzir a atividade de água e aumentar a vida-de-prateleira desses produtos. A sacarose e o açúcar invertido são os mais usados na produção desses alimentos.

\section{TEXTURIZAÇ̃̃O}

Os açúcares apresentam também a propriedade funcional de afetar a textura do alimento, são texturizantes. Essa propriedade decorre da elevada solubilidade dos açúcares em água. Os açúcares apresentam diferença de solubilidade, em função de sua forma anomérica ( $\alpha$ ou $\beta$ ). Devido à capacidade dos açúcares de ligarem água, podem ser adicionados aos alimentos e modificarem sua textura. Os açúcares são normalmente adicionados na forma de cristais ou de xaropes.

A diferença de solubilidade entre os açúcares pode ser usada na fabricação de caramelos duros com tempo variável de duração na boca. A adição de um maior teor de glicose num caramelo duro diminui sua velocidade de dissolução.

Os caramelos duros e transparentes são produzidos com soluções supersaturadas de açúcares (sacarose, glicose ou açúcar invertido). Nesses produtos, esses açúcares encontram-se em um estado amorfo instável e contêm maia água que no seu estado cristalino. No estado amorfo também chamado estado vítreo, as moléculas de açúcar estão mais afastadas do que no estado cristalino. Como esse estado é instável, o açúcar pode passar ao estado cristalino e, nesse caso, o excesso de água será eliminado e, consequentemente o caramelo ficará pegajoso.

Nos caramelos moles, os açúcares encontram-se na forma cristalina e, o tamanho dos cristais deve ser controlado para evitar que esses fiquem grandes, dificultando a mastigação do caramelo. 0 controle de crescimento dos cristais é realizado pela adição de misturas de açúcar ou do açúcar na sua forma anomérica desejada (sementes de cristalização), que irão retardar a velocidade de crescimento dos cristais, ou ainda pela agitação da massa ao cristalizar, resultando assim em muitos núcleos de cristalização, garantindo um crescimento pequeno e uniforme dos cristais. 0 grande núcleo de pequenos cristais torna o caramelo opaco e facilita a sua mastigação.

\section{LIGAÇÃO COM FLAVORIZANTES}

Em muitos alimentos, principalmente naqueles sujeitos aos processos de secagem convencional e liofilização, os carboidratos podem ser importantes devido à sua capacidade de reter compostos voláteis aromáticos e pigmentos naturais.

Entre os compostos voláteis estão incluídos vários aldeídos, cetonas, ésteres, ácidos carboxílicos e, eles são efetivamente retidos nos alimentos mais por dissacarídeos do que por monossacarídeos. Alguns carboidratos como dextrinas são capazes de formar sistemas que prendem o composto flavorizante e o protegem. Alguns polissacarídeos são extremamente eficientes nessa função, como, por exemplo, a goma arábica. A goma arábica forma uma película em torno dos compostos flavorizantes e os protege de absorção de umidade, perdas por evaporação ou oxidação química. 


\section{DOÇURA}

A doçura de alguns mono e dissacarídeos é uma de suas propriedades funcionais mais reconhecidas e mais agradáveis. Os poliálcoois apresentam a vantagem de serem menos calóricos que seus açúcares correspondentes. 0 padrão de doçura é a sacarose, ao qual se atribui arbitrariamente um valor de doçura relativa de 100. A intensidade do sabor doce de um alimento varia com o açúcar e com sua concentração no alimento.

Com exceção da sacarose, a doçura diminui com o aumento do número de unidades de monossacarídeos nos oligossacarídeos porque apenas uma unidade de monossacarídeo interage com a mucoproteína do receptor da língua.

\section{REAÇÕES QUÍMICAS DE CARBOIDRATOS HIDRÓLISE}

A hidrólise dos monossacarídeos, oligossacarídeos e polissacarídeos é influenciada por vários fatores, tais como $\mathrm{pH}$, temperatura, configuração anomérica (sendo $\alpha$ mais suscetível que $\beta$ ), forma e tamanho do anel. Nos polissacarídeos, a sensibilidade à hidrólise diminui com o aumento de associações intermoleculares. As ligações glicosídicas são mais facilmente quebradas em meios ácidos que alcalinos.

Os carboidratos são também hidrolisados por enzimas. A ligação glicosídica da sacarose é muito sensível à hidrólise mesmo em condições fracamente ácidas a baixas temperaturas e presença de pequenos filmes de água. A água pode ser gerada por decomposição térmica e reações de condensação de dissacarídeos, promovendo sua hidrólise em um estado aparentemente seco. Como resultado da hidrólise da sacarose, os açúcares redutores liberados podem participar de reações de escurecimento, produzindo cores e odores indesejáveis. A hidrólise ácida da sacarose resulta em uma mistura equimolar dos 2 monossacarídeos dos quais é composta: D-glicose e D-frutose.

A hidrólise pode ser realizada também pela enzima invertase. Esta reação é comercialmente importante, porque os 2 monossacarídeos misturados apresentam um sabor mais doce que a sacarose e são mais úteis na preparação de balas, sorvetes e refrigerantes. Comercialmente, a glicose é denominada de dextrose e a frutose de levulose.

\section{MUTARROTAÇÃO}

É a primeira e mais simples alteração que ocorre nos açúcares e que consiste na abertura do anel hemiacetálico. Os isômeros $\alpha$ e $\beta$ de mono e oligossacarídeos redutores na forma de cristais são estáveis em relação a sua atividade óptica o que não ocorre quando em solução. Esse fenômeno é denominado de mutarrotação. É uma reação catalisada por ácidos e bases. Todos os mono e oligossacarídeos redutores sofrem esse fenômeno.

\section{ENOLIZACÃ̃O}

Na presença de uma concentração maior do que a necessária de ácido ou base para produzir mutarrotação de açúcares redutores, ocorre outro fenômeno, efetivamente catalisado por base. Inicialmente, o anel heterocíclico do açúcar se abre e produz um enol, substância extremamente instável. Conforme o par de elétrons da dupla ligação do enol se movimenta um composto será formado. Na faixa de $\mathrm{pH}$ de $3-4$, a maioria dos açúcares redutores são estáveis.

\section{REAÇÕES DE DESIDRATAÇÃO}

Por meio de uma sequência de reações de desidratação as pentoses, eliminam 3 moléculas de água e formam o 2-furaldeído (furfural) e as hexoses o 5-hidroximetil-2-furaldeído, comumente chamado de Hidroximetilfurfural (HMF). Essa reação ocorre em meios ácidos, sob aquecimento. 0 principal mecanismo é a $\beta$ eliminação e envolve também a enolização. Por um mecanismo semelhante, obtém-se 2 -furaldeído (furfural) a partir das pentoses. O furaldeído é volátil, enquanto o HMF não é. O HMF é menos estável que o furaldeído e se decompõe em ácido levulínico e ácido fórmico. Esses 2 ácidos são produzidos em maior quantidade quando as soluções são fortemente ácidas. 
A fragmentação da cadeia carbônica desses produtos principais de desidratação conduz a compostos como: ácido levulínico, ácido fórmico, acetoína, diacetil, ácido láctico, ácido pirúvico e acético. Alguns desses produtos apresentam aromas pronunciados e sabores desejáveis ou indesejáveis.
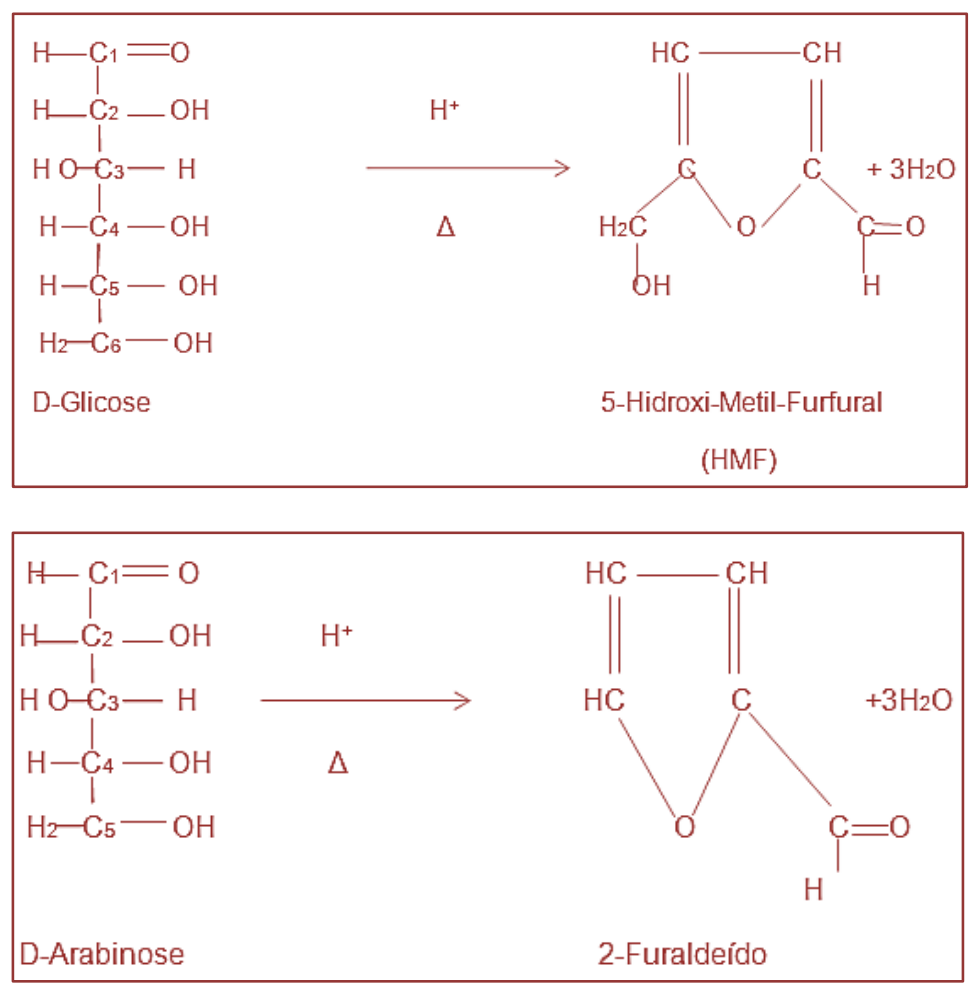

Fonte: Ribeiro; Seravalli; 2004

\section{REAÇÕES DE ESCURECIMENTO}

As reações que provocam o escurecimento dos alimentos podem ser oxidativas ou não oxidativas. 0 escurecimento oxidativo ou enzimático é uma reação entre o oxigênio e um substrato fenólico catalisado pela enzima polifenoloxidase e não envolve carboidratos.

O escurecimento não oxidativo ou não enzimático é muito importante em alimentos, envolve o fenômeno da caramelização e/ou a interação de proteínas ou aminas com carboidratos (Reação de Maillard).

A intensidade das reações de escurecimento não enzimático em alimentos depende da quantidade e do tipo de carboidrato presente. Apesar da reação de escurecimento não enzimático ocorrer principalmente entre açúcares redutores e aminoácidos, a degradação do açúcar, bem como a degradação oxidativa do ácido ascórbico e adicional condensação de compostos carbonílicos formados com grupos amina presentes, resulta na formação de pigmentos escuros. As reações de escurecimento não enzimático em alimentos estão associadas com aquecimento e armazenamento e podem ser subdivididas em 3 mecanismos, conforme tabela abaixo.

Tabela - Mecanismos das reações de escurecimento não enzimática

\begin{tabular}{|c|c|c|c|c|}
\hline Mecanismo & $\begin{array}{c}\text { Requerimento } \\
\text { de Oxigênio }\end{array}$ & $\begin{array}{c}\text { Requerimento } \\
\text { de NH2 }\end{array}$ & pH ótimo & Produto final \\
\hline Maillard & Não & Sim & $>7,0$ & Melanoidinas \\
\hline Caramelização & Não & Não & 3,0 a 9,0 & Caramelo \\
\hline $\begin{array}{c}\text { Oxidação de ácido } \\
\text { ascórbico }\end{array}$ & $\operatorname{Sim}$ & Não & $3,0<\mathrm{pH}<5,0$ & Melanoidinas \\
\hline
\end{tabular}




\section{REAÇÃO DE CARAMELIZAÇÃO}

Esta reação envolve a degradação de açúcares. Os açúcares no estado sólido são relativamente estáveis ao aquecimento moderado, mas em temperaturas maiores que $120^{\circ} \mathrm{C}$ são pirolisados para diversos produtos de degradação de alto peso moleculares e escuros, denominados caramelos. Tem mecanismo desconhecido. Sabe-se que o aquecimento provoca a quebra de ligações glicosídicas, quando elas existem como na sacarose, abertura do anel hemiacetálico, formação de novas ligações glicosídicas. Como resultado ocorre a formação de polímeros insaturados, os caramelos.

0 caramelo é um corante marrom e, com limitações, é também um agente flavorizante preparado através da pirólise do açúcar. Quando a caramelização ocorre sem qualquer catalisador a 200-240ํㅡ, caramelos de baixa intensidade de cor são obtidos e são mais úteis como agentes flavorizantes do que como corantes.

Os caramelos obtidos a partir do uso de catalisadores necessitam de temperaturas mais baixas (130 $200^{\circ} \mathrm{C}$ ) e apresentam uma alta intensidade de cor, sendo utilizados como corantes alimentícios. 0 uso de sais de amônio, como catalisador, resulta em caramelos mais escuros.

A sacarose é usada para produção de aromas e corantes de caramelo, via reação de caramelização. Ela é aquecida em solução com ácido ou sais de amônio para a produção de vários produtos usados em alimentos e bebidas, como por exemplo, refrigerante tipo "cola" e cervejas.

\section{REAÇÃO DE MAILLARD}

Essa reação é extremamente desejável em alguns alimentos como café, cacau, carne cozida, pão, bolos, pois confere o sabor, aroma e cor característicos a esses alimentos, mas é extremamente indesejável em outros como leite em pó, ovos e derivados desidratados. Essa reação pode resultar na perda de nutrientes como os aminoácidos do alimento. É uma reação muito complexa e estudada, mas cujo mecanismo ainda não foi totalmente elucidado.

Como resultado dessa reação, são produzidos muitos produtos diferentes que irão conferir sabor e aroma ao alimento. 0 escurecimento se deve à produção de melanoidinas, polímeros insaturados, e cuja cor é mais intensa quanto maior for seu peso molecular. A cor pode variar de marrom-claro até preto.

A reação ocorre entre açúcares redutores e aminoácidos principalmente lisina e histidina. Compreende 3 fases: inicial, intermediária e final. A fase inicial ocorre entre açúcares redutores e aminoácidos na proporção 1:1 e resulta em produtos ainda incolores e sem sabor e aroma. A reação inicial entre o açúcar redutor e o aminoácido é uma reação de condensação com perda de uma molécula de água. Na fase intermediária inicia-se a percepção de aromas. A cor torna-se amarelada. Desenvolve-se o poder redutor em solução e o pH diminui. Na fase final ocorre o desenvolvimento da cor, aroma e sabor. Diferentes sabores e aromas são produzidos nessa reação, em função de diferentes aminoácidos. Os aminoácidos definem o sabor e aroma, sem depender do tipo de açúcar redutor.

\section{FATORES QUE AFETAM A REAÇÃO DE MAILLARD}

\section{TEMPERATURA}

A reação inicialmente ocorre preferencialmente em temperaturas maiores que $70^{\circ} \mathrm{C}$, porém continua em temperaturas da ordem de $20^{\circ} \mathrm{C}$ e durante o processamento ou armazenamento. A elevação da temperatura resulta em um rápido aumento da velocidade de escurecimento, aumentando de 2 a 3 vezes para cada aumento de $10^{\circ} \mathrm{C}$. Os alimentos congelados são pouco afetados pela Reação de Maillard.

\section{$\mathrm{pH}$}

A velocidade da reação é máxima em pH próximo a neutralidade (pH 6 - 7). Em meio ácido, predomina a forma protonada do grupo $\mathrm{NH}_{2}$ do aminoácido, eliminando a nucleofilicidade desse grupo e, dessa forma, retardando a reação com o grupo carbonila do açúcar. Em meio alcalino, ocorre rápida degradação de carboidratos independentemente da presença de aminoácidos. Em valores de pH abaixo de 5,00 e na presença de ácido ascórbico, ocorre a reação de escurecimento provocada pela oxidação do ácido ascórbico (vitamina C). 


\section{TIPO DE AÇÚCAR}

A presença do açúcar redutor é essencial para a interação da carbonila com os grupos amina livres. A natureza do açúcar determina a reatividade, pentoses são mais reativas que hexoses e essas mais que dissacarídeos. Os dissacarídeos não redutores somente são utilizados na reação após a hidrólise da ligação glicosídica.

\section{ATIVIDADE DE ÁGUA}

Em valores de atividade de água maiores que 0,9 a velocidade da reação diminui, devido à diluição dos reagentes. E em valores menores que o intervalo $0,2-0,25$ a velocidade tende a zero devido à ausência de solvente, necessário para permitir que íons e moléculas se movimentem e se encontrem. Ocorre um maior escurecimento em valores de atividade de água intermediários $(0,5$ a 0,8).

\section{CATALISADORES}

A velocidade da reação é acelerada por ânions como citrato, fosfato e por íons metálicos como cobre divalente em meio ácido.

\section{INIBIÇÃo DA REAÇÃo DE MAILLARD}

Tratamentos usados para inibir a Reação de Maillard:

- Uso de açúcares não redutores, por exemplo, a sacarose, em condições nas quais não possa ser hidrolisada.

- Redução da atividade de água ou aumento da diluição.

- Remoção de açúcares redutores por enzima, como, por exemplo, o tratamento com a enzima glicose-oxidase em ovos produzindo ácido glucônico a partir da glicose.

- Adição de $\mathrm{SO}_{2}$ que inibe o escurecimento enzimático, porém dependendo da concentração usada, pode provocar o aparecimento de odores desagradáveis, além de destruir as vitaminas $\mathrm{B}_{1}$ (tiamina) e C. Atua como inibidor, bloqueando a reação da carbonila dos carboidratos com o grupo amina dos aminoácidos e evitando a condensação destes compostos pela formação irreversível de sulfonatos.

\section{POLISSACARÍDEOS}

Os polissacarídeos de interesse são: amido, dextrina, glicogênio. São menos solúveis e mais estáveis que os açúcares mais simples. 0 amido e o glicogênio são geralmente completamente digeríveis.

\section{AMIDO}

É encontrado apenas em vegetais, em ambas as formas: a) Amilose - que possui cadeias retas e longas de unidade de glicose; b) Amilopectina - que possui cadeias ramificadas de unidades de glicose. Os grânulos de amido de vários tamanhos e formas estão encerrados dentro das células do vegetal pelas paredes de celulose. Características do amido: 1 . Os grânulos são insolúveis em $\mathrm{H}_{2} \mathrm{O}$ fria; 2 . 0 cozimento causa o intumescimento dos grânulos e a mistura se torna um gel; 3. 0 cozimento edemacia e rompe a célula para deixar o amido disponível para os processos digestivos enzimáticos.

Amido Alimentar Modificado (amido resistente à ação das enzimas): É agente espessante usado em alimentos preparados comercialmente, como molhos de saladas, recheios de tortas, sopas enlatadas, caldos, pudins enlatados e alimentos para bebês. A modificação permite a retenção de propriedades espessantes desejáveis, perdidas no amido comum após esfriamento e estocagem. 


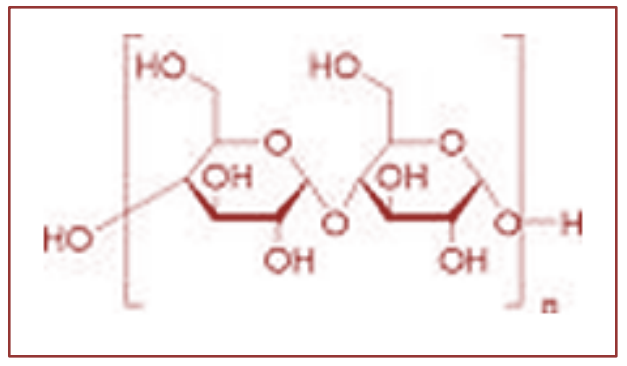

\section{DEXTRINAS}

Produtos intermediários que ocorrem na hidrólise do amido. São formadas durante a digestão e também como resultado de uma variedade de processos comerciais que usam ácidos, enzimas ou calor seco. Diminuindo em tamanho, as moléculas dos sacarídeos vão aumentando em solubilidade e doçura. Aplicações comerciais: em xarope de milho (rico em dextrinas). Dextrose: É a glicose produzida pela hidrólise de amido de milho.

\section{GLICOGÊNIO}

Forma de armazenamento de carboidratos em humanos e animais. É a primeira e a mais prontamente disponível fonte de glicose e energia. Consiste de: cadeias ramificadas de unidades de glicose semelhantes àquelas do amido de vegetal ( 340g de glicogênio é armazenado no fígado e nos músculos). As pequenas quantidades de glicogênio nos alimentos animais são convertidas em ácido láctico antes de estarem disponíveis para o consumo.

\section{CELULOSE E HEMICELULOSE}

Constituem a estrutura celular dos vegetais. A celulose lembra o amido, pois contém muitas moléculas de glicose em forma não ramificada parecida com a amilose, porém unidas de uma forma que não são hidrolisadas pelas enzimas que hidrolisam o amido. É encontrada apenas em vegetais: polpa de frutas e vegetais, peles, talos, folhas, cobertura externa de grãos, nozes, sementes e leguminosas. As hemiceluloses são polissacarídeos não celulósicos. Diferem das celuloses na estrutura, pois têm menos unidades de glicose. Podem consistir de hexoses, pentoses e formar ácidos destes compostos. Os produtos de fibra sintéticos, como a metilcelulose e a carboximetilcelulose (CMC), são usados em laxativos, assim como na produção de alimentos de baixas calorias devido a sua propriedade de produzir volume e sociedade. A CMC auxilia na solubilização de algumas proteínas, como gelatina, caseína e proteínas da soja, e esse comportamento é devido à formação de um complexo entre CMC e a proteína.

Em função de suas propriedades e ausência de toxicidade, a CMC possui ampla aplicação em alimentos: ela atua como ligante e espessante em pudins, queijos fundidos, recheios etc. Sua capacidade de ligar água é muito útil em sorvetes e sobremesas geladas, retardando o crescimento de cristais de gelo. Ela retarda o crescimento de cristais de açúcar em confeitos, coberturas e xaropes e possui um excelente efeito de aumento de volume em bolos e tortas. Auxilia na estabilização de emulsões e também fornece um aumento de volume excelente em alimentos dietéticos sem açúcar. Em bebidas de baixo valor calórico, a CMC auxilia na retenção do gás carbônico. 


\section{Celulose}

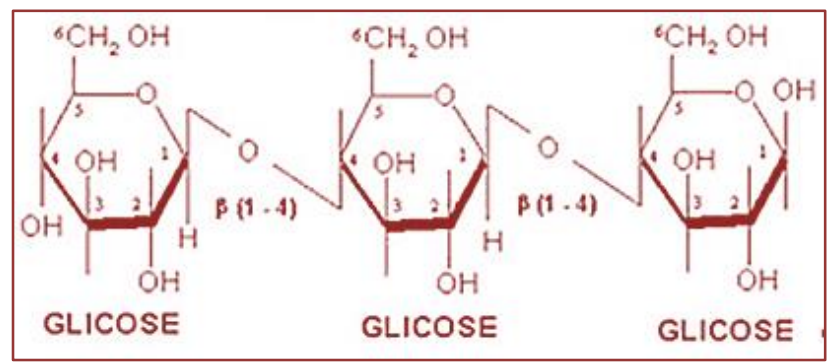

\section{PECTINA}

Polissacarídeo, não celulósico, constituído de unidades de um derivado de galactose. Como absorve $\mathrm{H}_{2} \mathrm{O}$ e forma um gel, é usada para fazer geleias e gelatinas. É encontrada em maçãs, frutas cítricas, morangos e outros.

\section{GOMAS E MUCILAGENS}

São polímeros de cadeia longa, de alto peso molecular e são estudadas por sua capacidade de texturização. São extraídas de algas marinhas, sementes, e de colágeno animal. Algumas são produzidas por síntese microbiana e outras pela modificação de polissacarídeos naturais. São semelhantes à pectina, exceto pelo fato de que as unidades de galactose estão combinadas a outros açúcares (glicose) e polissacarídeos, encontrados em secreções vegetais ou sementes e são adicionadas a alimentos processados para conferir propriedades ou qualidades específicas.

As gomas dissolvem-se ou dispersam-se em água e aumentam a viscosidade, são espessantes e podem ou não ser gelificantes. Apresentam também propriedades secundárias, incluindo estabilização de emulsões, controle de cristalização, inibição de sinérese, encapsulação e formação de filmes.

A dissolução das gomas em meio aquoso depende de uma dispersão adequada e das condições físicoquímicas do meio, ou seja, pH, presença de íons e temperatura. A importância da utilização das gomas reside, principalmente, nas suas habilidades de aumentar viscosidade e formar gel e seus efeitos estabilizantes de dispersões. As principais gomas usadas em alimentos são as extraídas de sementes, as provenientes de exsudatos de árvores, e as extraídas de algas marinhas.

\section{DAS GOMAS EXTRAÍDAS DE SEMENTES TEM-SE:}

[1] Goma guar: É um polissacarídeo extraído das sementes de Cyamopsis tetragonolobus. É uma galactomanana que contém unidades de manose e galactose. Fornece dispersões de alta viscosidade. Sua viscosidade é pouco afetada pelo $\mathrm{pH}$ e por sais, entretanto, grandes quantidades de sacarose podem reduzir sua viscosidade. É usada em queijos para eliminar sinérese, contribui para o corpo e resistência dos sorvetes a choques térmicos.

[2] Goma locusta: É extraída da semente da planta Ceratonia siliqua. É uma galactomanana como a goma guar. É apenas levemente solúvel em água à temperatura ambiente. É utilizado em gelados comestíveis como espessante e também para promover a cremosidade e o corpo desses produtos, raramente são utilizados sozinhos, mas sim combinados com outras gomas como CMC, carragena, xantana e goma guar. A goma guar é mais usada que a locusta devido ao seu menor custo e à maior facilidade de dispersão. 


\section{DAS GOMAS EXTRAÍDAS DE EXSUDATOS DE ÁRVORES TEM-SE}

[1] Goma arábica: É extraída do exsudato de árvores Acacia. É uma goma neutra ou levemente ácida e contém cálcio, magnésio e potássio. É solúvel em água e produz dispersões baixa viscosidade. Retarda ou previne a cristalização de açúcar em confeitos, estabiliza emulsões e atua como espessante. Em bebidas atua como emulsificante e estabilizante de espuma. É um fixador de aromas em misturas secas para bebidas.

[2] Goma tragacante: É um exsudato da planta Astragalus. É usada em temperos de saladas, por conta de sua estabilidade ao calor e às condições ácidas. Em sobremesas geladas dá corpo e textura.

\section{DAS GOMAS EXTRAÍDAS DE ALGAS MARINHAS TEM-SE}

[1] Goma carragena: É extraída de algas Chondrus crispus, também conhecida como musgo irlandês. É uma galactomanana. Interage com muitas gomas, principalmente com a locusta. A goma carragena é usada em sistemas à base de leite ou de água para estabilizar as suspensões. É usada em leites achocolatados para evitar a precipitação do chocolate. É um estabilizante de emulsões em produtos como queijos fundidos. Em sorvetes, atua como inibidor de cristalização do gelo e é normalmente usado em combinação com carboximetilcelulose (CMC) e/ou goma locusta.

[2] Goma Agar-agar: É extraído de algas vermelhas da classe Rhodophyceae. Apresenta propriedades e estrutura muito semelhante à goma carragena. É usada em gelados comestíveis para inibir a sinérese e dar textura, em bolos e tortas para controlar a atividade de água. Normalmente é usada junto com outras gomas como tragacante, locusta e/ou gelatina.

[3] Alginato: É extraído de algas marrons da classe Phaeophyceae. 0 alginato é muito usado para aumentar a viscosidade em baixas concentrações. Viscosidade elevada pode ser obtida a partir da adição de íons cálcio à solução da goma. Essa característica é muito usada para aumentar a viscosidade de sucos de frutas e permitir a formação da dispersão dos insolúveis no suco. São usados em sorvetes, contribuindo para o corpo, textura e resistência à formação de grandes cristais de gelo. São usadas em recheios de tortas, coberturas para bolos, para a textura característica desses produtos. Em pudins e similares, são usados como espessantes, e em cervejas como estabilizantes de espuma.

\section{DAS GOMAS PRODUZIDAS POR MICRORGANISMOS TEM-SE:}

[1] Goma xantana: É um polissacarídeo extracelular produzido por microrganismos da espécie Xanthomonas. Foi a primeira goma produzida em escala industrial por fermentação. É ideal para a estabilização de dispersões aquosas, suspensões e emulsões. Em alguns produtos enlatados, a goma é usada como substituto parcial do amido para dar penetração mais rápida de calor, resultando em menor perda da qualidade do produto. Em bebidas, a goma xantana promove o sabor e em sucos atua como estabilizante. Em alimentos que usam amido como espessante, a goma xantana aumenta a estabilidade ao congelamento-descongelamento e diminui a sinérese. A sua propriedade de formar géis com a goma locusta pode ser usada na preparação de pudins instantâneos à base de leite.

[2] Goma Gelana: É o nome genérico para o polissacarídeo extracelular elaborado pela bactéria Sphinggomonas elodea (antes denominada de Pseudomonas elodea). É uma goma de fácil aplicação, com boa estabilidade, inclusive em produtos ácidos.

[3] Goma konjac: A matéria prima para essa goma é o tubérculo da planta Amorphophallus konjac. Ela apresenta propriedades funcionais de agente espessante e gelificante excelentes. Fornece propriedades únicas e desejáveis de textura a produtos alimentícios. É estável ao calor e às condições ácidas. Apresenta alto teor de fibras dietéticas. É excelente espessante em alimentos. Está sendo usada como agente espessante no crescimento de cristais de gelo em substituição à goma locusta, muito usada em derivados de leite como sorvetes e "cream cheese". Essa goma é pouco conhecida no Ocidente, porém no Japão, já é usada há centenas de anos. Atualmente o seu uso é proibido em alimentos pelo "Food and Drug Administration" (FDA) nos EUA e também pela legislação brasileira.

[4] Polissacarídeos: São encontrados em frutos do mar e algas. Ex.: carragenina, adicionada como agente espessante e estabilizante em muitos produtos alimentares processados. 


\section{FIBRA ALIMENTAR}

Um grupo de componentes funcionais dos alimentos, dos mais importantes é a fibra alimentar também chamada dietética. A fibra alimentar é fornecida principalmente pelos alimentos de origem vegetal, conforme tabela abaixo.

TABELA: Principais componentes da fibra dietética

\begin{tabular}{|c|c|}
\hline $\begin{array}{c}\text { Classificação } \\
\text { Química }\end{array}$ & Componentes \\
\hline \multirow{7}{*}{$\begin{array}{l}\text { Substâncias não- } \\
\text { glicídicas }\end{array}$} & Proteínas \\
\hline & Cutina \\
\hline & Cera \\
\hline & Silício \\
\hline & Suberina \\
\hline & Lignina \\
\hline & Quitina \\
\hline \multirow{7}{*}{$\begin{array}{l}\text { Polissacarídios não- } \\
\text { amido }\end{array}$} & Celulose \\
\hline & Hemicelulose \\
\hline & Substâncias Pécticas \\
\hline & Gomas \\
\hline & Mucilagens \\
\hline & Polissacarídios de origem vegetal \\
\hline & Polissacarídios de origem bacteriana \\
\hline Amido & Amido resistente \\
\hline
\end{tabular}

Fonte: Liberato; Mendes da Silva, 2002

Os constituintes da fibra alimentar sob o ponto de vista químico, podem ser divididos em: componentes não-glicídicos, polissacarídeos não-amido e amido resistente. Os componentes não glicídios somados à celulose, hemiceluloses e substâncias pécticas representam os componentes da parede celular vegetal. Gomas, mucilagens, polissacarídeos não-amido de origem vegetal e bacteriana, juntamente com o amido resistente representam os demais componentes. Quanto às propriedades físico-químicas, a fibra alimentar é dividida em fração insolúvel e fração solúvel em água.

Estudos epidemiológicos correlacionam a maior ingestão de fibra alimentar com a menor incidência de várias doenças, como câncer de cólon e de reto, câncer de mama, diabetes, aterosclerose, apendicite, doença de Crohn, síndrome de cólon irritado, hemorroidas e doença diverticular

A fração insolúvel da fibra alimentar é formada principalmente de celulose, lignina e hemiceluloses insolúveis. Essa fração exerce um efeito físico-mecânico, aumentando o volume do bolo alimentar e das fezes, diminuindo o tempo de trânsito intestinal. Esses componentes, ao se hidratarem, ligam não somente água, podendo ligar também elementos minerais, vitaminas, sais biliares, hormônios e lipídeos.

As fibras insolúveis, com essas ações, podem produzir efeitos benéficos à saúde, como aumentar o peristaltismo intestinal e aliviar principalmente as constipações intestinais, as hemorroidas, a síndrome do cólon irritado e a doença diverticular. Pelo fato de aumentar o bolo fecal, aumentar a velocidade do trânsito intestinal e poder ligar sais biliares, ácidos graxos, estrógenos e compostos fenólicos as fibras podem arrastar com as fezes substâncias mutagênicas e pró-cancerígenas, aumentando o volume fecal e diminuindo a incidência de tumores intestinais, particularmente do cólon e do reto. Os componentes da fibra insolúvel, particularmente celulose e lignina praticamente não sofrem degradação microbiológica no intestino grosso, sendo quase que totalmente excretados nas fezes.

Os componentes solúveis da fibra alimentar, como gomas, mucilagens, substâncias pécticas ou outros polissacarídeos solúveis, por outro lado, adsorvem muita água, já a partir do estômago, formando sistemas 
viscosos de consistência gelatinosa, podendo retardar o esvaziamento gástrico e o trânsito do conteúdo intestinal. Esses polissacarídeos tendem a formar uma camada viscosa de proteção à mucosa do estômago e intestino delgado, dificultando a absorção, principalmente de açúcares e gorduras, sendo este, talvez, o mecanismo pelo qual esses polissacarídeos ajudam a baixar os níveis lipídicos sanguineos e teciduais, assim como a glicemia.

No intestino grosso, a fibra solúvel sofre fermentação anaeróbica pelas bactérias, principalmente do cólon, como a dos gêneros Bacterioides, Bifidobacterium, Clostridium, Streptococcus e Escherichia. Em média, cerca de $70 \%$ da fibra alimentar pode ser fermentada no intestino grosso, entretanto, esse valor irá depender da fonte de fibra. Vários produtos de fermentação da fibra poderão ser aproveitados como fonte de energia.

Os principais produtos da fermentação das fibras no cólon são ácidos graxos de cadeias curtas (acético, propiônico, butírico), metano, amônia e hidrogênio. Os produtos da fermentação podem ocasionar uma série de alterações no cólon como a diminuição do pH intraluminal, redução da solubilidade dos ácidos biliares e dos ácidos graxos livres, controle seletivo das linhagens da microflora bacteriana e, consequentemente, dos ácidos graxos de cadeias curtas que se formam.

Estudos experimentais realizados com animais indicam que existem vários mecanismos pelos quais as fibras podem contribuir com benefícios à saúde. Alguns tipos de câncer em humanos têm sido associados à alimentação como o de estômago, cólon, pâncreas, mama, ovário, endométrio uterino e próstata.

A maioria dos trabalhos, relacionando a alimentação com o câncer de cólon, indica que existe uma redução dos riscos com a ingestão elevada de frutas, hortaliças e grãos integrais. Várias hipóteses procuram explicar a ação preventiva da fibra alimentar no câncer de cólon, a saber:

[1] redução da exposição a agentes carcinogênicos pelo aumento do bolo fecal e/ou diminuição do tempo de trânsito do bolo intestinal.

[2] redução da produção de ácidos biliares secundários (desoxicólico e litocólico) pela diminuição de bactérias produtoras de enzimas (7- $\alpha$-desidroxilases) responsáveis pela conversão dos ácidos biliares primários (cólico e quenodesoxicólico) nos ácidos secundários que são pró-carcinogênicos;

[3] efeito ligante da fibra a hormônios (estrógenos) promotores de câncer de cólon e mama.

[4] produção de ácidos graxos de cadeias curtas que contribuem para o abaixamento do pH do bolo intestinal e desempenham papel fisiológico importante em nível de tecido epitelial.

Ácidos graxos de cadeias curtas, particularmente o butírico, desempenham funções importantes na prevenção do câncer de cólon como:

[1] Inibe o crescimento e a proliferação de células tumorais (in vitro);

[2] Induz a diferenciação de células tumorais, promovendo seu retorno à normalidade;

[3] Restabelece, em células cancerosas, a morte celular geneticamente programada ou apoptose.

\section{AMIDO}

0 amido, um polissacarídeo, é a principal reserva alimentar dos vegetais, ocorrendo como grânulos microscópicos nas raízes, tubérculos e nas sementes dos vegetais. 0 grânulo de amido natural é essencialmente constituído de dois polissacarídeos: a amilopectina e a amilose, associadas entre si por pontes de hidrogênio. Além destes componentes, o grânulo contém compostos nitrogenados, lipídeos e minerais em baixa concentração.

Os dois principais componentes do amido (amilose e amilopectina) são polímeros polidispersos de alto peso molecular. A maioria dos amidos de diferentes fontes botânicas contém de 15 a $30 \%$ de amilose. Em certas variedades de milho, sorgo, cevada e arroz, referido como "waxy" ou "ceroso", o amido consiste quase que inteiramente de amilopectina.

Medições físicas mostram que a amilose, nos casos típicos, é constituída por mais de 1000 unidades de Dglicopiranosídio unidas por ligação $\alpha$ entre o C1 de uma unidade e o C4 da seguinte. Ou seja, no tamanho do anel das suas unidades glicosídicas e na configuração das ligações glicosídicas entre elas, a amilose se parece com a maltose. As cadeias de unidades de D-glicose com as ligações $\alpha$-glicosídicas, como as da 
amilose, tendem a assumir configuração helicoidal. Esta configuração faz com que a molécula da amilose tenha forma muito compacta, embora o seu peso molecular seja bastante elevado (150.000 a 600.000 daltons). A amilose tem a maioria de suas cadeias interligadas do mesmo modo que a amilopectina, para formar uma estrutura levemente ramificada. 0 pequeno grau de ramificação da amilose não é suficiente para afetar as propriedades físicas deste polímero.

A amilopectina tem estrutura semelhante à da amilose (isto é, ligações $\alpha:(1 \rightarrow 4)$, porém as cadeias da amilopectina são ramificadas. A ramificação ocorre entre o C6 de uma unidade de glicose e o C1 de outra, e ocorre em intervalos de 20 a 25 unidades. Medições físicas mostram que o peso molecular da amilopectina vai de 1 a 6 milhões de daltons; portanto, a amilopectina é constituída por centenas de cadeias interligadas, cada qual com 20 a 25 unidades de glicose.

A amilopectina é um polímero formado por cadeias curtas, de amilose, ligadas entre si, formando uma estrutura ramificada. Estas ramificações, ou a ligação entre estas cadeias curtas de amilose, são formadas por ligações $\alpha:(1 \rightarrow 6)$. As propriedades físicas e biológicas da amilopectina são profundamente afetadas pela presença de 4 a 5\% de ligações inter-cadeias. Existem fortes evidências de que a amilopectina é a responsável pela cristalinidade do grânulo de amido.

Um terceiro componente (material intermediário) tem sido obtido de diversos amidos. A quantidade desse material varia, dependendo da fonte botânica, mas é da ordem de 5 a $10 \%$ na maioria dos amidos de cereais, porém sua estrutura ainda não está bem definida. Esse material intermediário consiste de cadeias lineares com grau de polimerização (DP) variando de 50 a 200 e moléculas levemente ramificadas de baixo peso molecular $\left(<10^{6}\right)$ e com comprimento de cadeia maior que o comprimento da amilopectina normal.

Quando observado na luz polarizada, o grânulo de amido mostra birrefringência ou a típica "cruz de malta". Birrefringência e cristalinidade não estão relacionadas. Um alto grau de organização molecular no grânulo está relacionado à birrefringência, sem qualquer referência à forma cristalina.

O grânulo de amido natural é um sistema polimérico parcialmente cristalino (cristalinidade variando de 15 a 45\%). A cristalinidade do grânulo é principalmente atribuída à amilopectina. As cadeias "s" da amilopectina estão presentes como duplas hélices arranjadas em estruturas tridimensionais cristalinas.

\section{AMIDO RESISTENTE}

O amido, após o ataque inicial na parte superior do trato intestinal é digerido e absorvido no intestino delgado humano. Foi encontrada, depois, uma fração de amido que permanece indigerível, após a digestão exaustiva durante a determinação de fibra dietética criando desta forma o conceito de "amido resistente" ao ataque enzimático. Ele é definido como a soma do amido e seus produtos de degradação não absorvidos no intestino delgado, podendo contudo, ser fermentado no intestino grosso pela microflora.

0 amido resistente foi classificado em diferentes tipos. 0 tipo I representa o amido inacessível fisicamente, localizado nas células das plantas. Essa fração pode ser encontrada em grãos comestíveis, parcialmente moídos, em sementes e legumes. 0 tipo II é o amido granular, natural, encontrado em alimentos contendo amido não cozido, ex: bananas. A alta densidade e a cristalinidade parcial reduzem a suscetibilidade enzimática. 0 tipo III, é uma fração do amido não digerível, formada após o tratamento térmico, podendo estar presente em produtos como batatas e ervilhas cozidas e resfriadas.

A resistência ao ataque enzimático pode ser introduzida através da modificação química ou térmica do amido. Estas frações de amido resistente são conhecidas como tipo IV. A formação de ligações glicosídicas diferentes das $\alpha:(1 \rightarrow 4)$ e/ou $\alpha:(1 \rightarrow 6)$ por tratamento térmico reduz a disponibilidade ao ataque das enzimas amilolíticas. Também ligações cruzadas ou a presença de alguns substituintes podem reduzir a digestibilidade do amido.

Além dos fatores intrínsecos do amido que reduzem a digestibilidade, vários fatores extrínsecos ao amido podem ser responsáveis pela limitação de sua hidrólise, como a viscosidade do meio (alimento), que tem impacto sobre a difusão das enzimas, o tamanho das partículas do alimento e o tempo de trânsito através do cólon.

Por não ser digerido no intestino delgado, o amido resistente diminui o valor calórico dos alimentos. Como resultado da fermentação do amido resistente no intestino grosso pela microflora, observa-se também uma excreção de ácidos graxos de cadeia curta. 0 amido resistente pode proteger contra câncer do cólon por aumentar o volume fecal e estabilizar a proliferação de células colônicas. 
O amido resistente tipo III, para ser formado passa primeiro pela gelatinização. Durante este processo, a organização molecular do grânulo é gradual e irreversivelmente destruída. A temperatura de gelatinização é característica do tipo de amido e dependente da transição vítrea da fração amorfa do amido. Neste processo, a organização molecular (e também a birrefringência) desaparece, o grânulo de amido perde a cristalinidade (fusão de cristalitos detectado pela análise de difração de raio X), água é absorvida e o inchamento do grânulo é seguido pela lixiviação das moléculas do polímero (demonstrado através do aumento da viscosidade) os grânulos de amido são rompidos e parcial solubilização é obtida.

A pasta de amido formada obtida após a gelatinização não é estável, ocorrendo uma transformação estrutural posterior denominada retrogradação. Depois da retrogradação, um sistema polimérico parcialmente cristalino é novamente obtido. A cristalização neste sistema pode assim ser influenciada pelo ambiente amorfo.

Vários autores consideram que analiticamente amido resistente à enzima deveria ser incluído nos resultados de fibra dietética porque suas propriedades fisiológicas são semelhantes a certas fibras polissacarídicas. Amido retrogradado, também chamado amido resistente tipo III, é o mais comum amido resistente na dieta humana e, a partir do ponto de vista tecnológico, é o tipo mais importante, porque é formado principalmente como resultado do processamento do alimento. 0 amido resistente é altamente dependente da origem botânica. $\mathrm{O}$ amido resistente tipo IV, é formado pela modificação química ou térmica do amido (Fonte: Costa; Rosa, 2010).

\section{AMIDOS MODIFICADOS}

0 amido, devido a sua estrutura básica, apresenta algumas características que, de certa forma, limitam a sua utilização pela indústria de alimentos. Assim sendo, várias pesquisas têm sido conduzidas a fim de modificar as suas propriedades, permitindo-lhe ter comportamentos previsíveis em sistemas específicos de alimentos.

Modificações químicas e físicas do grânulo de amido afetam a suscetibilidade enzimática e por sua vez, as mudanças ocasionadas nos grânulos também se refletem nas suas propriedades físico-químicas. Processos de modificação já desenvolvidos têm possibilitado a produção comercial de derivados de amido, que se tornaram imprescindíveis na composição de alimentos, onde são usados como aditivos para espessar, estabilizar ou dar texturas características a uma larga variedade de produtos alimentícios.

A introdução de grupos substituintes na molécula de amido, através de ligações éster, produz géis mais claros e suaves, com alta viscosidade, que podem ser estocados por períodos longos em condições de refrigeração ou congelamento, sem apresentarem sinérese. Amidos modificados incluem modificações que mudam a estrutura química de algumas das unidades de D-glucopiranosil. Essas modificações normalmente envolvem oxidação, esterificação ou eterificação.

A derivatização do amido é conduzida com o objetivo de modificar as características de gelatinização e cozimento do amido granular, diminuir a tendência a retrogradação, aumentar a sua capacidade de retenção de água em dispersões de amido a baixa temperatura, minimizando a sinérese, melhorar o caráter hidrofílico, dar propriedades hidrofóbicas, e/ou introduzir substituintes iônicos.

0 mais antigo tipo de modificação é o tratamento com ácido. Produz amido modificado por ácido. Os primeiros trabalhos foram realizados por Lintner e Naegeli no final dos anos de 1800. Outra forma de modificação é obtida através de introdução de ligações cruzadas. Isto significa a ligação covalente de duas moléculas de amido para formar uma molécula maior.

0 processo é acompanhado por formação de um diéster com ácido fosfórico $\left(\mathrm{POCl}_{3}\right.$ é o reagente mais comum) ou por formação de uma ligação éter (Epiclorohidrina, reagente mais comum). Embora geralmente se considere a ligação cruzada ocorrendo entre moléculas, que ela poderia também ocorrer dentro da molécula de amilopectina, contudo tais ligações dentro da molécula não teriam um grande efeito sobre as propriedades do amido.

Altos níveis de ligações cruzadas aumentam a temperatura de gelatinização do amido. Amidos com alto grau de ligações cruzadas podem ser preparados e não gelatinizam quando são fervidos em água ou esterilizados em autoclave.

Amido usado em sistemas alimentícios têm geralmente ligações cruzadas em uma pequena extensão. A quantidade de reação é designada por "graus de substituição" (GS). Em alimento, o GS é geralmente entre 
0,01 e 0,1. Um importante uso de amido com ligações cruzadas é na produção de sistemas viscosos em meio ácido.

Outra forma de modificação de amidos é através da substituição. Caso seja formado um monoéster de ácido fosfórico no amido ele é dito estar substituído. Também aqui se obtém uma pasta de amido com maior viscosidade. A substituição impede a retrogradação e opacidade dos géis de amido.

Outros amidos modificados são obtidos como amidos oxidados (geralmente tratados com hipoclorito). São usados principalmente em aplicações não alimentícias (lavanderia e manufatura de papéis), podendo ser usados em formulações de panificação e para melhorar a adesão de produtos cárnicos.

Alimentos funcionais são produtos que contêm em sua composição constituintes biologicamente ativos que promovem efeitos metabólicos ou fisiológicos no organismo resultando em redução do risco de desenvolvimento de doenças. Na última década observou-se crescente interesse pelas fibras alimentares pelo menos quanto à sua importância na saúde do cólon humano como marcador do estado de saúde geral.

Assim, outros componentes da dieta, além das fibras alimentares, tornaram-se importantes para a investigação científica e aplicação a vários alimentos denominados funcionais. A maior reserva energética dos vegetais superiores é o amido, um carboidrato encontrado no cloroplasto das plantas na forma de grânulos. Na década de 1980, no Japão observou-se que uma fração do amido ingerido nas refeições não era digerido pelas enzimas humanas, chegando direto ao cólon, onde servia como substrato para a flora bacteriana. Essa fração foi então denominada de amido resistente às enzimas (AR).

0 amido resistente assim como as fibras, atua na redução do índice glicêmico dos alimentos, proporcionando menor resposta glicêmica, portanto menor resposta insulínica auxiliando no tratamento da diabetes, especialmente a do tipo 2. Acredita-se que o AR seja um candidato ideal para controle glicêmico em condições de diabetes. Além disso, a fermentação do AR no cólon assume especial significado, já que pode causar efeitos benéficos, como a produção de ácidos graxos de cadeia curta. Após a absorção, os ácidos propiônico e acético podem ser responsáveis, pelo menos em parte, pela propriedade das fibras de reduzir o colesterol. 0 ácido butírico que serve como combustível primário para as células do intestino grosso, pode manter a saúde e a integridade do cólon sendo possível a redução do risco de câncer de cólon por suprimir a proliferação das células tumorais., induzindo apoptose e diferenciação.

De todos os polissacarídeos, o amido é o único produzido em pequenos agregados individuais, com tamanhos que variam de acordo com sua origem. Seus grânulos podem ser isolados de raízes, tubérculos, caules, folhas, sementes, frutos e pólen de plantas, tendo dimensões entre 0,5 a $175 \mu \mathrm{m}$. 0 grânulo de amido natural é essencialmente constituído de dois polissacarídeos: a amilopectina e a amilose, associados entre si por pontes de hidrogênio. Além destes componentes, o grânulo contém compostos nitrogenados, lipídeos e minerais em baixa concentração. Dentro de um grânulo de amido há regiões cristalinas consistindo principalmente de amilopectina rodeada por uma estrutura aparentemente amorfa constituída principalmente de amilose.

O amido é o principal componente da farinha de trigo (Triticum aestivum L.), e por isso age como determinante na qualidade do produto alimentar dele derivado. A maioria dos atributos funcionais do amido pode estar relacionada às interações dele com a água nos processos conhecidos como gelatinização e retrogradação.

Modificações químicas são frequentemente realizadas nos amidos para alterar suas propriedades naturais, a fim de que eles possam ser utilizados como alimento ou em aplicações industriais. Amidos quimicamente modificados podem ter suas propriedades físico-químicas profundamente alteradas quando comparadas com seus amidos originais, principalmente quanto a sua suscetibilidade enzimática.

Amidos modificados apresentam alterações na estrutura química de algumas das unidades glucopiranosídicas do polímero. Essas modificações usualmente envolvem oxidação, esterificação ou eterificação, clorações, piroconversões, e a introdução de ligações cruzadas.

As reações de esterificação do amido são variadas, sendo muito conhecidas aquelas onde são usados ácidos carboxílicos como ácido acético, anidrido acético, misturas de anidrido acético e ácido acético, acetato de vinila e outros. De relevante importância são as reações de esterificação dos amidos fosforilados.

Os ésteres podem ser orgânicos ou inorgânicos e suas propriedades dependem não só dos grupos substituintes, mas também do grau de substituição, das condições de reação ( $\mathrm{pH}$, temperatura, tempo, concentração dos reagentes) e do tipo de amido usado. A introdução de grupos iônicos como fosfatos, ou 
hidrofóbicos como acetil ou propionil nas unidades de glucose, impedem a associação das moléculas do amido, inibindo a retrogradação.

A fosforilação é um método muito usado para a modificação do amido em que a repulsão entre cadeias de amido adjacentes, causadas pela introdução de grupos fosfato, carregados negativamente, reduz as associações entre cadeias e facilita a hidratação do amido. 0 tripolifosfato de sódio (TPS) é um anidrido parcial do ácido ortofosfórico e sua reação com o amido tem sido comparada àquelas dos anidridos orgânicos com amido.

Em 1964 foram descritos métodos para preparação de éster de amido fosforilado com baixo e alto teor de fosfato, utilizando tripolifosfato de sódio (TPS) e ortofosfato de sódio, respectivamente. Em 1971 foi obtido amido monofosforilado com TPS e relacionadas suas propriedades com seus graus de substituição. Alguns pesquisadores concluíram que a fosforilação do amido de milho normal trouxe mudanças significativas nas suas propriedades e claridade de pasta assim como na estabilidade ao congelamentodescongelamento, benéficas em um grande número de aplicações alimentícias.

Apesar do mecanismo da reação de esterificação do amido por TPS ainda não estar totalmente esclarecido, fatores como temperatura e tempo da reação, $\mathrm{pH}$ do meio, concentração de TPS e tipo do amido influenciam no grau de substituição do amido fosforilado. Um aumento do grau de substituição de amido fosforilado com o aumento da concentração de TPS foi observado por pesquisadores.

0 amido fosforilado tem sido empregado na formulação do creme de milho enlatado, na formulação de bolos, queijos, no tratamento de tripa natural e tem sido objeto de controvérsia entre alguns pesquisadores com relação a sua digestibilidade. Pesquisadores estudaram a digestibilidade in vivo e in vitro de diferentes amidos (trigo, milho, batata) modificados por fosforilação com baixos graus de substituição concluíram que, esses compostos são degradados e utilizados pelo organismo por mecanismos semelhantes aos dos amidos in natura quando submetidos ao processo de cocção. Outros autores, trabalhando com os amidos de arroz, batata, milho normal, extender e ceroso, modificados por fosforilação com vários graus de substituição, verificaram haver uma redução na suscetibilidade à hidrólise com $\alpha$-amilase, havendo portanto a possibilidade de aumentar o teor de amido resistente com o incremento do grau de substituição de grupos hidroxila por fosfato (Fonte: Liberato; Mendes da Silva, 2002).

Os efeitos fisiológicos do AR são em parte, comparáveis aos descritos para fibra alimentar incluindo: melhora na resposta glicêmica e insulinêmica, já que desempenha papel importante na diabetes e na síndrome metabólica, melhora na saúde intestinal contribuindo para reduzir o risco de várias doenças colônicas, melhora do perfil lipídico, absorção de minerais.

Pelo fato do amido resistente não ser digerido no intestino delgado, ele diminui o valor calórico dos alimentos. Como um resultado da fermentação do amido resistente no intestino grosso pela microflora, observa-se também uma produção de metabólitos desejáveis tais como ácidos graxos de cadeia curta que estão relacionados com a integridade do trato intestinal e a função imunológica, abaixamento do pH fecal e significante aumento de excreção diária de butirato. A produção de butirato é um indicador de saúde colônica em humanos.

0 amido resistente pode proteger contra câncer do cólon por aumentar o volume fecal e estabilizar a proliferação de células colônicas. Vários autores consideram que analiticamente o amido resistente a enzimas deve ser incluído nos resultados de fibras dietéticas já que suas propriedades fisiológicas são semelhantes a certas fibras polissacarídicas, como as celuloses e as pectinas encontraram frações de amido resistente em torno de $1,0 \%$ no pão branco. Pesquisadores concluíram então, que somente quantidades limitadas de amido resistente estão presentes no pão. Considerando o potencial de utilização do amido de trigo fosforilado como uma possível fonte de amido resistente em produtos de panificação, Liberato e Silva (2002) realizaram um trabalho desenvolvendo pães com amido resistente, a partir de fosforilação com TPS, ao invés do amido comum. Várias amostras de pães foram produzidas a partir da obtenção da fosforilação do amido extraído da farinha de trigo comercial com a introdução do mesmo junto ao glúten de forma a obter-se novamente uma farinha de trigo própria para panificação com qualidades especiais.

Os testes sensoriais e demais análises aprovaram as modificações através do paladar e do tempo de vida dos produtos (Fonte: Liberato; Silva; 2002). 
Fotografia de pães experimentais obtidos com o amido de trigo modificado com tripolifosfato de sódio (TPS), em diferentes proporções com glúten vital.

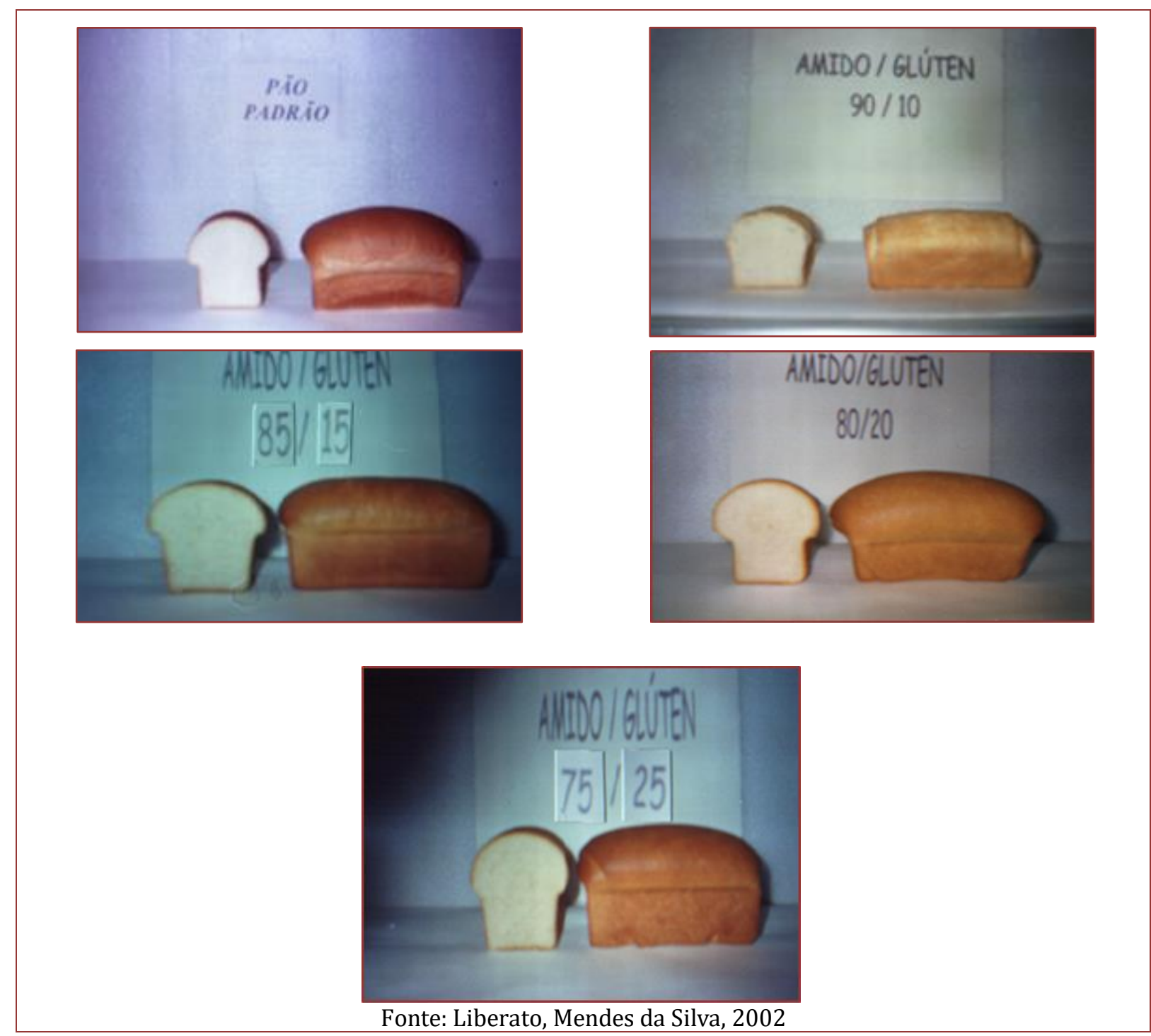




\section{CAPÍTULO \\ 03 Lipídeos}

Os lipídeos são compostos que ocorrem na natureza. É possível também defini-los como moléculas orgânicas naturais isoladas de células e tecidos por extração com solventes orgânicos não polares. As características que melhor definem os lipídeos estão relacionadas com sua solubilidade, pois são relativamente insolúveis na água e são solúveis nos solventes não polares, tais como o éter, o clorofórmio e o benzeno. Gorduras e óleos são lipídeos típicos em termos de solubilidade, mas esse fato não define realmente sua natureza química. Quimicamente se pode afirmar que o lipídeo é uma mistura de compostos que compartilham algumas propriedades com base em semelhanças estruturais, principalmente uma preponderância de grupos apolares.

Uma classificação que se relacione com a sua natureza química poderia ser aquela que encaixa os lipídeos em dois grupos principais. 0 primeiro grupo consiste em compostos de cadeia aberta com grupos de cabeça polar e longas caudas apolares, e inclui os ácidos graxos, os triacilgliceróis, os esfingolipídios, os fosfoacilgliceróis e os glicolipídios. 0 segundo grupo principal consiste em compostos de anéis fundidos (cadeias cíclicas), os esteroides, sendo um importante representante desse grupo o colesterol.

Também é possível classificar os lipídeos como simples e complexos. Nesse caso, são chamados Lipídeos simples os ésteres que, por hidrólise total dão origem somente a ácidos graxos e álcoois.

Podem ser

[1] Gorduras e óleos, que são ésteres de ácidos graxos com o glicerol. São denominados triacilgliceróis (TAG). Podem ser encontrados em células de origem animal, vegetal ou microbiana. São os maiores componentes do tecido adiposo, e, junto com as proteínas e carboidratos, constituem os principais componentes estruturais de todas as células vivas. As gorduras exercem funções nutricionais importantes, suprindo calorias ( $9 \mathrm{kcal} / \mathrm{g})$ e ácidos graxos essenciais, além do transporte das vitaminas lipossolúveis para o interior das células. São responsáveis pelo isolamento térmico e permeabilidade das paredes celulares; contribuem para o sabor e palatabilidade dos alimentos e também para a sensação de saciedade após a alimentação.

[2] Ceras que são ésteres de ácidos graxos com álcoois monohidroxílicos de pesos moleculares mais elevados e geralmente de cadeia linear como, por exemplo, o palmitato de miricila $\mathrm{CH}_{3}\left(\mathrm{CH}_{2}\right)_{14} \mathrm{COO}_{\left(\mathrm{CH}_{2}\right)_{29}}$ $\mathrm{CH}_{3}$, encontrado em grande quantidade na cera do favo de mel de abelha.

Os Lipídeos complexos (ou lipídeos compostos) são os ésteres de ácidos contendo outros grupos além de álcoois e de ácidos graxos, como:

[1] Fosfolipídeos (ou Fosfatídeos) que são lipídeos que contêm, além de ácidos graxos e um álcool, um resíduo de ácido fosfórico e, frequentemente, têm bases nitrogenadas e outros substituintes, como nos glicerofosfolipídeos, o álcool é o glicerol e, nos esfingolipídeos, o álcool é a esfingosina.

[2] Glicolipídeos (Glicoesfingolipídeos ou Cerebrosídeos), que são lipídeos que contêm um ácido graxo, esfingosina e carboidrato.

Outros Lipídeos Complexos são lipídeos tais como Sulfolipídeos (contêm enxofre) e Aminolipídeos (contêm grupos amino). As lipoproteínas também podem ser enquadradas nesta categoria, bem como os Precursores e derivados de lipídeos que são obtidos na sua maioria por hidrólise dos lipídeos simples e composto. Incluem: ácidos graxos, glicerol, esteroides, álcoois, além do glicerol e esteróis, aldeídos graxos e corpos cetônicos, hidrocarbonetos, vitaminas lipossolúveis, hormônios e pigmentos. 


\section{ÁCIDOS GRAXOS}

São ácidos carboxílicos alifáticos. São considerados compostos anfipáticos porque o grupo carboxila é hidrofílico e a cauda de hidrocarboneto é hidrofóbica. Ocorrem como ésteres nas gorduras naturais e nos óleos. Neste caso, geralmente, têm cadeia linear e número par de átomos de carbono. Podem ter cadeia saturada ou insaturada. As propriedades físicas e fisiológicas dos ácidos graxos dependem do comprimento da cadeia e do grau de insaturação. Ex.: Os pontos de fusão dos ácidos graxos, com o no․ par de átomos de carbono, aumentam com o aumento do comprimento da cadeia e diminuem com a insaturação. Os ácidos graxos possuem cadeias retas de hidrocarboneto terminando em um grupo carboxila de um lado e um grupo metila no outro.

A maioria das cadeias dos ácidos graxos tem entre 4 e 22C, com aqueles de 16 e 18 carbonos, ou ácidos graxos de cadeia longa, sendo os de maior prevalência. No organismo, os ácidos graxos são uma parte importante dos Fosfolipídeos nas Membranas Celulares.

Os ácidos graxos são classificados pelo $n^{0}$ de $C$, pela posição da $1^{\text {a }}$ dupla ligação e pelo $\mathrm{n}^{\mathrm{o}}$ de duplas ligações. A localização da 1aㅗ dupla ligação, contada a partir da terminação metila do Ácido Graxo, é designada pelo $\mathrm{n}^{\mathrm{o}} \omega$ (ômega).

Ex.: Ácido Linoleico: $\omega-6$ (ômega-6) 18:2. Ou seja: possui 18C, 2 duplas, sendo a $1^{\text {a }}$ dupla no $\mathrm{C}_{6}$ contado a partir do $\mathrm{CH}_{3}$.

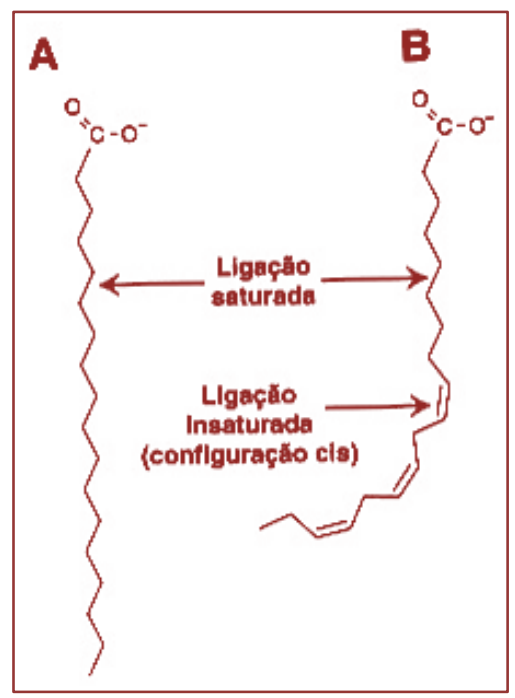

Fonte: Marzocco; Torres, 1999

\section{ÁCIDOS GRAXOS SATURADOS}

Contêm o no máximo de $\mathrm{H}$ que a cadeia pode suportar. Estão concentrados em certos alimentos animais (carnes bovina, frango, porco, laticínios) e alimentos vegetais (palmeira, semente de palmeira e óleo de coco). 0 nível de saturação determina a consistência da gordura à temperatura ambiente. Em geral, quanto > a cadeia, mais saturada ela é e mais dura a gordura será em temperatura ambiente. Exceção: óleo de coco (altamente saturado e líquido à temperatura ambiente por causa da prevalência ou predominância dos Ácidos Graxos de cadeia curta, menos que seis átomos de carbonos.

Os ácidos graxos saturados, encontrados na maioria dos óleos e gorduras, são: láurico (C12), mirístico (C14), palmítico (C16), e esteárico (C18). Os ácidos láurico e mirístico estão presentes em grandes proporções nos óleos de babaçu e de amêndoa de palma (dendê), enquanto os ácidos palmítico e esteárico ocorrem, frequentemente, na maioria dos óleos e gorduras.

Ácidos graxos saturados de cadeia mais curta, tais como C4 a C10, são encontrados junto com ácidos de cadeias mais longas, na gordura do leite. Ácidos graxos saturados com mais de 24 carbonos raramente ocorrem em óleos comestíveis, mas são encontrados em ceras. 


\section{ÁCIDOS GRAXOS MONOINSATURADOS}

Contêm apenas uma dupla ligação. Ex.: ácido oleico (presente em azeite de oliva, óleo de canela, óleo de amendoim, amendoins, nozes pecãs, amêndoas e abacates). No organismo, o ácido oleico é formado pelo estearato através da ação da enzima dessaturase. Os ácidos graxos monoinsaturados podem desempenhar um papel no tratamento do diabetes.

\section{ÁCIDOS GRAXOS TRANS}

A maior parte dos ácidos graxos monoinsaturados nos alimentos ocorre na forma cis, significando que os H estão do mesmo lado da dupla ligação. No processamento dos alimentos, os ácidos graxos trans são formados quando se adiciona $\mathrm{H}_{2}$ a óleos líquidos para torná-los semi-sólidos e mais estáveis. As fontes de ácidos graxos trans na dieta são margarina dura, gordura, frituras, produtos de panificação ricos em gorduras e lanches salgados.

Tabela: Ácidos graxos saturados

\begin{tabular}{|c|c|c|}
\hline \multicolumn{3}{|r|}{ Ácidos graxos saturados } \\
\hline Nome comum & $\begin{array}{l}\text { Número } \\
\text { de } \\
\text { átomos } \\
\text { de C }\end{array}$ & Descrição \\
\hline Fórmico ${ }^{1}$ & 1 & Toma parte no metabolismo de unidades " $\mathrm{C}_{1}$ " (formato). \\
\hline Acético & 2 & $\begin{array}{l}\text { Principal produto final da fermentação de carboidratos por organismos do } \\
\text { rúmen }^{2} \text {. }\end{array}$ \\
\hline Propiônico & 3 & Um produto final da fermentação de carboidratos por organismos do rúmen². \\
\hline Butírico & 4 & \multirow{3}{*}{$\begin{array}{l}\text { Em certas gorduras em pequenas quantidades (especialmente manteiga). Um } \\
\text { produto final da fermentação de carboidratos por organismos do rúmen². }\end{array}$} \\
\hline Valérico & 5 & \\
\hline Capróico & 6 & \\
\hline Caprílio (octanóico) & 8 & \multirow{2}{*}{$\begin{array}{l}\text { Em pequenas quantidades em muitas gorduras (incluindo manteiga), } \\
\text { especialmente aquelas de origem vegetal. }\end{array}$} \\
\hline Cáprico (Decanoico) & 10 & \\
\hline Láurico & 12 & Espermacete, canela, cerne da palmeira, óleos de coco, manteiga. \\
\hline Mirístico & 14 & Noz moscada, cerne da palmeira, óleos de coco, mirta. \\
\hline Palmítico & 16 & \multirow{2}{*}{ Comum em todas as gorduras animais e vegetais. } \\
\hline Esteárico & 18 & \\
\hline Araquídico & 20 & Óleo de amendoim (araquis). \\
\hline Beênico & 22 & Sementes. \\
\hline Lignocérico ${ }^{2}$ & 24 & Cerebrosídeos, óleo de amendoim. \\
\hline
\end{tabular}

2Também formado no cecum de herbívoros e em menor quantidade no cólon humano.

Tabela: Ácidos graxos insaturados (Monoinsaturados, Poliinsaturados, Eicosanóides)

\begin{tabular}{|c|c|c|c|c|l|}
\hline \multicolumn{6}{|c|}{ Ácidos graxos insaturados de importância fisiológica e nutricional } \\
\begin{tabular}{|c|c|c|c|c|} 
Número de átomos de C \\
e número e posição das \\
duplas ligações
\end{tabular} & Séries & Nome comum & Nome sistemático & \multicolumn{1}{|c|}{ Ocorrência } \\
\hline $16: 1 ; 9$ & $\omega 7$ & Palmitoléico & \multicolumn{1}{|c|}{ Cis-9-Hexadecenóico } & Em quase todas as gorduras. \\
\hline $18: 1 ; 9$ & $\omega 9$ & Oleico & Cis-9-Octadecenoico & $\begin{array}{l}\text { Principalmente o ácido graxo } \\
\text { mais comum nas gorduras } \\
\text { naurais. }\end{array}$ \\
\hline $18: 1 ; 9$ & $\omega 9$ & Elaídico & trans-9-Octadecenoico & $\begin{array}{l}\text { Gorduras hidrogenadas e de } \\
\text { ruminantes. }\end{array}$ \\
\hline $22: 1 ; 13$ & $\omega 9$ & Erúcico & Cis-13-Docosenoico & $\begin{array}{l}\text { Óleos de sementes de coiza e } \\
\text { mostarda. }\end{array}$ \\
\hline $24: 1 ; 15$ & $\omega 9$ & Nervônico & Cis-15-Tetracosenoico & Nos cerebrospideos. \\
\hline
\end{tabular}


Tabela: Ácidos graxos insaturados (Monoinsaturados, Poliinsaturados, Eicosanóides)

\begin{tabular}{|c|c|c|c|c|}
\hline \multicolumn{5}{|c|}{ Ácidos dienoicos (2 duplas ligações) } \\
\hline $18: 2 ; 9,12$ & $\omega 6$ & Linoleico & $\begin{array}{l}\text { Todo-cis-9, 12- } \\
\text { Octadecadienóico }\end{array}$ & $\begin{array}{l}\text { Milho, amendoim, algodão, soja, } \\
\text { muitos óleos de plantas. }\end{array}$ \\
\hline \multicolumn{5}{|c|}{ Ácidos trienóicos (3 duplas ligações) } \\
\hline $18: 3 ; 6,9,12$ & $\omega 6$ & y-Linolênico & $\begin{array}{l}\text { todo-cis-6,9,12- } \\
\text { Octadecatrienoico }\end{array}$ & $\begin{array}{l}\text { Algumas plantas, p.ex., óleo de } \\
\text { prímula da tarde; ácidos graxos } \\
\text { menores em animais. }\end{array}$ \\
\hline $18: 3 ; 9,12,15$ & $\omega 3$ & $\alpha$-Linolênico & $\begin{array}{l}\text { todo-cis-9,12,15- } \\
\text { Octadecatrienoico }\end{array}$ & $\begin{array}{l}\text { Frequentemente, encontrado } \\
\text { com o ácido linoleico, porém } \\
\text { particularmente no óleo de } \\
\text { linhaça. }\end{array}$ \\
\hline \multicolumn{5}{|c|}{ Ácidos tetraenóicos (4 duplas ligações) } \\
\hline $20: 4 ; 5,8,11,14$ & $\omega 6$ & Araquidôni-co & $\begin{array}{l}\text { todo-cis-5,8,11,14- } \\
\text { Eicosatetraenoico }\end{array}$ & $\begin{array}{l}\text { Encontrado em gorduras } \\
\text { animais e no óleo de amedoim; } \\
\text { importante componente de } \\
\text { fosfolipídeos dos animais. }\end{array}$ \\
\hline \multicolumn{5}{|c|}{ Ácidos pentaenoicos (5 duplas ligações) } \\
\hline $20: 5 ; 5,8,11,14,17$ & $\omega 3$ & Trimnodôni-co & $\begin{array}{l}\text { todo-cis-5,8,11,14,17 - } \\
\text { Eicosatetraenoico }\end{array}$ & $\begin{array}{l}\text { Importante componente de óleos } \\
\text { de peixes, p.ex., óleo de fígado de } \\
\text { bacalhau, cavala, arenque e } \\
\text { salmão. }\end{array}$ \\
\hline $22: 5 ; 7,10,13,16,19$ & $\omega 3$ & $\begin{array}{l}\text { Clupanodô- } \\
\text { nico }\end{array}$ & $\begin{array}{l}\text { todo-cis-7,10,13,16,19- } \\
\text { Docosapentaenoico }\end{array}$ & $\begin{array}{l}\text { Óleo de peixe, fosfolipídeos do } \\
\text { cérebro. }\end{array}$ \\
\hline \multicolumn{5}{|c|}{ Ácidos hexaenoicos ( 6 duplas ligações) } \\
\hline $22: 6 ; 4,7,10,13,16,19$ & $\omega 3$ & Cervônico & $\begin{array}{l}\text { todo-cis-5,8,11,14- } \\
\text { Docosahexaenoico }\end{array}$ & $\begin{array}{l}\text { Óleos de peixe, fosfolipídeos do } \\
\text { cérebro. }\end{array}$ \\
\hline
\end{tabular}

(Fonte: Liberato; Oliveira, 2013)

Os ácidos graxos insaturados predominam nas plantas superiores e em animais que vivem em baixas temperaturas.

\section{ÁCIDOS GRAXOS INCOMUNS}

Os ácidos graxos incomuns contêm número ímpar de átomos de carbono. Ex.: ácido margárico, ácido malválico.

\section{ÁCIDOS GRAXOS ESSENCIAIS}

Os ácidos graxos essenciais produzem efeitos especiais no organismo vivo. Não podem ser produzidos pelo organismo humano. Devem ser administrados pelos alimentos. Exemplo: o ácido linoleico é transformado pelo organismo no ácido araquidônico (que é 4 vezes mais insaturado e com 20 carbonos). 0 ácido araquidônico é o ácido graxo verdadeiramente "essencial" para o organismo humano. 0 Ácido Linoleico $(\omega-6)$ e o Ácido $\alpha$ - Linolênico $(\omega-3)$ são os dois ácidos graxos essenciais na dieta porque previnem sintomas de deficiência e não podem ser sintetizados pelos seres humanos. Esses dois Ácidos Graxos são os compostos de origem para os outros ácidos graxos biologicamente ativos.

O Ácido Linoleico, através da ação das enzimas dessaturase, pode ser convertido em Ácido $\alpha$ - Linolênico e Ácido Araquidônico, e ambos podem desempenhar uma função no início do desenvolvimento cerebral. 0 Ácido Araquidônico pode prevenir a dermatite encontrada na deficiência de Ácido Graxo Essencial; portanto, tem atividade parcial de ácido graxo essencial. Devido ao fato do Ácido Araquidônico ser sintetizado a partir do Ácido Linoleico, ele se torna essencial, se a dieta for deficiente em Ácido Linoleico.

Na família do $\omega-3$, o Ácido docosaexaenóico (DHA, C22: $6 \omega-3$ ), desempenha uma função principal no funcionamento da retina e desenvolvimento cerebral, e acredita-se hoje que seja essencial para bebês. Essas famílias de Ácidos Graxos são também precursoras dos eicosanoides (prostaglandinas, tromboxanos e leucotrienos), compostos como hormônios, que ajudam no controle da pressão sanguínea, frequência cardíaca, dilatação vascular, coagulação sanguínea, lipólise e resposta imunológica. 
Cada família dá origem a uma série diferente de eicosanoides. Por exemplo: o Ácido Araquidônico (família (-6) é precursor de Prostaglandina, Tromboxano $A_{2}$, que causa agregação plaquetária, formação de coágulo e vasoconstrição.

Em contraste, os Ácidos Graxos $\omega-3$ favorecem a produção de prostaciclinas (que têm efeitos opostos, isto é, previnem a formação de coágulo e causam vasodilatação). Também inibem a enzima dessaturase, que diminui a produção de ácido Araquidônico e, consequentemente, de tromboxano $\mathrm{A}_{2}$. A ingestão na dieta dos Ácidos Graxos Essenciais está positivamente relacionada com suas concentrações nos ésteres de colesterol e fosfolipídeos no sangue, por isso, essas quantidades bioquímicas são usadas para confirmar a ingestão na dieta.

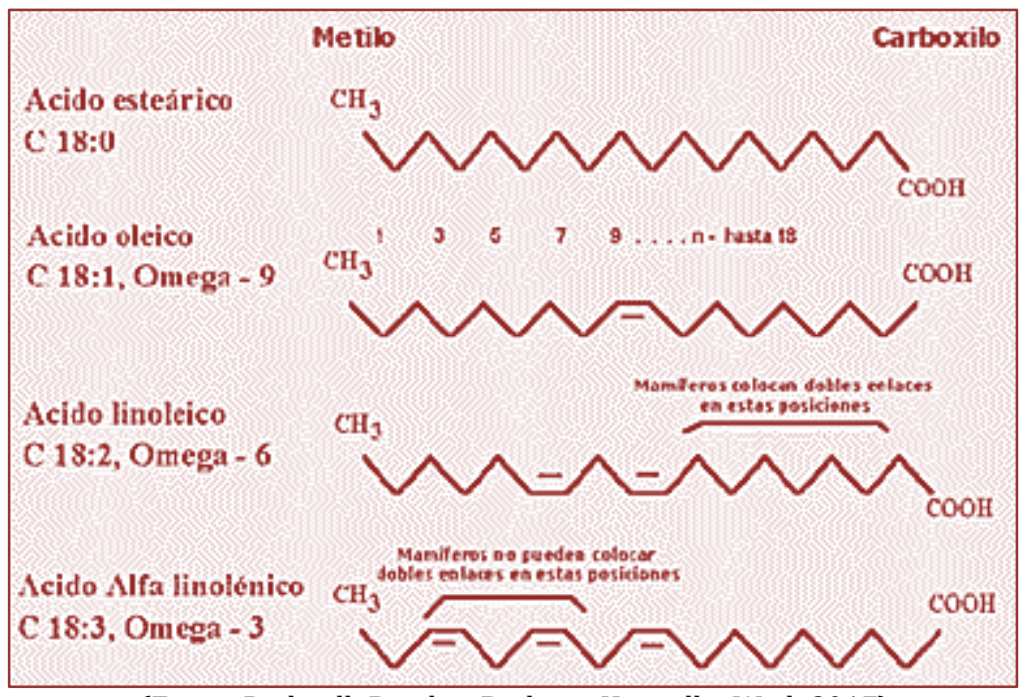

(Fonte: Rodwell; Bender; Botham; Kennelly; Weil; 2017)

\section{SINTOMAS DA DEFICIÊNCIA DE ÁCIDO LINOLÉICO w-6}

Dermatite e desenvolvimento precário em bebês alimentados com uma fórmula sem gordura.

Os animais também têm insuficiência reprodutiva e fígado gorduroso. A deficiência de Ácidos Graxos Essenciais em crianças e adultos tem sido observada durante um longo período de nutrição parenteral total sem gordura.

Uma deficiência de Ácido Linolênico $\omega-3$ produziu mudanças neurológicas (entorpecimento, parestesia, fraqueza, incapacidade de andar, visão embaçada) que foram revertidas quando o Ác. Linolênico foi fornecido. Outros sintomas da deficiência do $\omega-3$ são: dificuldades de aprendizado, eletrorretinograma anormal e acuidade visual prejudicada.

\section{ACILGLICERÓIS}

São produtos da reação de esterificação de uma molécula de glicerol com até três moléculas de ácidos graxos. Podem ser: Monoacilglicerol, Diacilglicerol e Triacilglicerol.

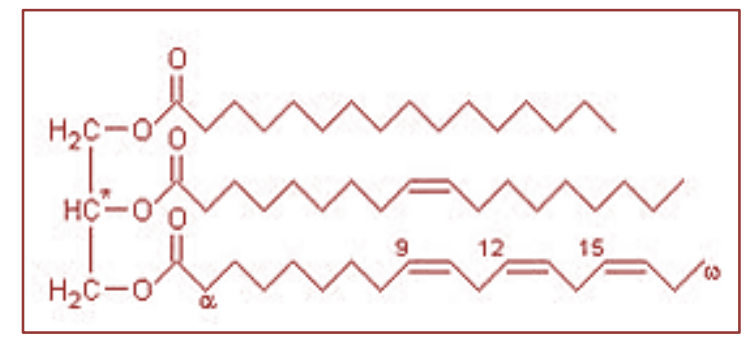

(Fonte: Marzocco; Torres, 1999) 


\section{TRIACILGLICERÓIS OU TRIGLICERÍDEOS (TAG)}

Os triacilgliceróis ou triglicerídeos são ésteres do álcool glicerol com ácidos graxos. Contêm uma molécula de Glicerol (um álcool triídrico) e um a três ácidos graxos na ligação do éster. São os óleos de vegetais ou as gorduras de origem animal. Suas propriedades físicas são determinadas pela proporção e estrutura química dos seus ácidos graxos constituintes. Os triacilgliceróis líquidos à temperatura ambiente são chamados em geral, óleos, e os que são sólidos são chamados gorduras. Os ácidos graxos menores e menos insaturados caracterizam as gorduras que são macias ou óleos líquidos em To ambiente. As gorduras sólidas (ex.: gordura da carne), contêm grandes quantidades de ácidos graxos de cadeia longa, isto é, ácidos palmítico (C16:0) esteárico (C18:0). As propriedades dos glicerídeos também são influenciadas pelo no $\omega$ e pela posição dos ác. graxos na molécula de glicerol. Nos alimentos, os lipídeos mais abundantes são os triacilgliceróis. Os triacilgliceróis são hidrolisados dando como resultado três ácidos graxos e o glicerol.

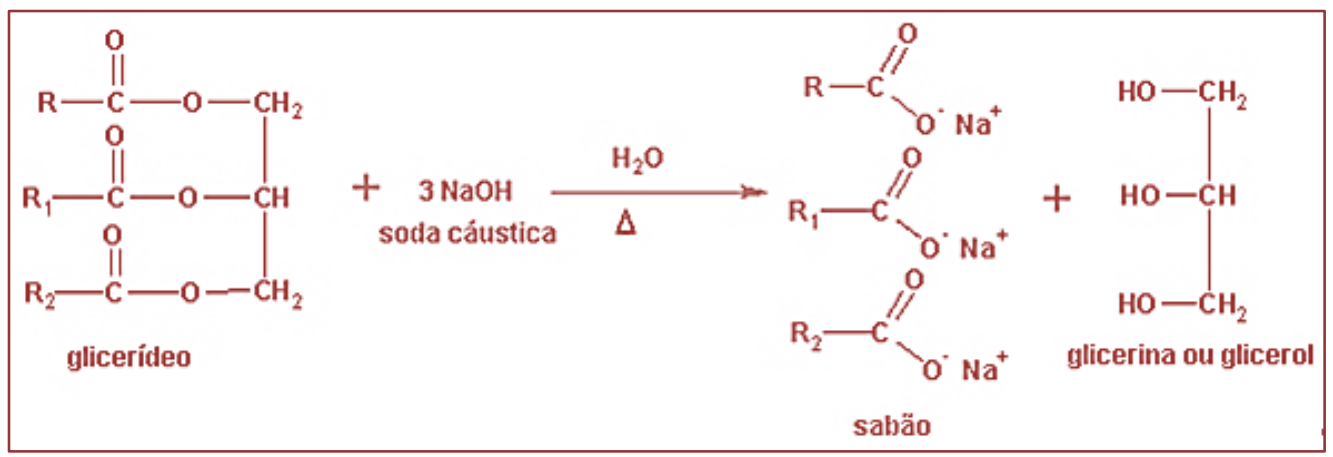

\section{FUNÇõES}

- ENERGIA: Devido a sua alta densidade energética e baixa solubilidade, os Triacilgliceróis (TAG) do tecido adiposo são a maior forma de armazenamento de energia no organismo.

- Os TAG são armazenados de forma mais eficiente que o GLICOGÊNIO, pois produzem $2 \frac{1}{2}$ vezes o ATP depois da oxidação e são armazenados sem $\mathrm{H}_{2} \mathrm{O}$. Geralmente, os seres humanos possuem algumas semanas de reservas adiposas, mas apenas o valor de cerca de um dia de glicogênio.

- $\quad 0$ tecido adiposo auxilia a manter órgãos e nervos em posição e protege-os contra choques e lesões traumáticas. (Efeito Amortecedor).

- A camada subcutânea de gordura isola o organismo, preservando o calor do organismo e mantendo a temperatura do organismo (Efeito Isolamento Térmico).

- As gorduras auxiliam no transporte e absorção de vitaminas lipossolúveis.

- Deprimem as secreções gástricas e tornam mais lento o esvaziamento gástrico.

- As gorduras adicionam o paladar da dieta e produzem uma sensação de saciedade após a refeição.

(Fonte: Liberato; Oliveira; 2013)

\section{HIPERTEXTO}

\section{HIDROGENAÇÃO DOS TRIACILGLICERÓIS}

As gorduras comercializadas para alimentação são obtidas pela hidrogenação parcial de óleos vegetais. 0 resultado são as gorduras "parcialmente hidrogenadas" presentes em muitos produtos alimentícios. A vantagem comercial da hidrogenação parcial é a maior duração da vida útil da gordura. Há, porém, um problema com a hidrogenação parcial. 0 catalisador isomeriza parte das duplas ligações não hidrogenadas e substitui o arranjo natural em cis por um arranjo artificial em trans; acumulam-se, porém, provas das gorduras em trans estarem associadas a riscos crescentes de moléstias cardiovasculares. 


\section{ÁCIDOS GRAXOS POLIINSATURADOS}

Os ácidos graxos poliinsaturados contêm duas ou mais duplas ligações. 0 ácido graxo poliinsaturado predominante na dieta é o Ácido Linoleico. Fontes de Ácido Linoleico são as sementes de vegetais e os óleos que produzem. Óleos que não são provenientes de sementes como: óleo de coco, óleo de palmeira, manteiga de cacau são fontes pobres de ácido linoleico. Existem duas principais famílias de Ácidos Graxos Poliinsaturados: $\omega-3$ e $\omega-6$. Essas famílias não são conversíveis, tendo funções bioquímicas muito diferentes.

As gorduras alimentícias são subdivididas em cinco grupos em função dos seus ácidos graxos predominantes esterificados no triglicerídeo.

\section{Grupo das gorduras do leite}

Caracteriza-se por apresentar quantidades substanciais de ácidos graxos de cadeia curta (C4 - C10). 0 principal representante é o ácido butírico, que representa 3 a $15 \%$ do total. Ácidos de cadeia longa também são encontrados, incluindo o ácido oleico (30 a 40\%), o ácido palmítico (25 a 32\%) e o ácido esteárico (10 a 15\%).

\section{Grupo do ácido láurico}

É o grupo onde o óleo apresenta, em sua composição, 40 a 50\% de ácido láurico (C12). Outros ácidos também encontrados, porém, em quantidades menores são os que têm C8, C10, C14, C16, C18, sendo que a maioria saturados, como por exemplo, nos óleos de coco e de babaçu.

\section{Grupo dos ácidos oléico-linoléico}

É o maior e mais variado grupo. As gorduras desse grupo são todas de origem vegetal. 0 grupo se caracteriza ainda por apresentar um teor menor que $20 \%$ de ácidos saturados. Os ácidos graxos presentes são os ácidos oleico e linoleico. Exemplos: óleos de algodão, milho, girassol e azeite de oliva.

\section{Grupo do ácido linolênico}

Esse grupo se caracteriza por apresentar quantidades substanciais de ácido linolênico, mas apresenta também altos teores dos ácidos oléico e linoléico. Por exemplo, o óleo de soja apresenta em média $23 \%$ de ácido oléico, $48 \%$ de ácido linoléico e $9 \%$ de ácido linolênico dos ácidos graxos presentes nos triglicerídeos, enquanto no óleo de milho, o teor de ácido oléico é de $28 \%$ e o linoléico $50 \%$, porém não apresenta ácido linolênico.

\section{Grupo das gorduras animais}

As gorduras animais apresentam também teores elevados dos ácidos oleico e linoleico. Esse grupo caracteriza-se por apresentar um alto teor de ácidos graxos saturados de alto peso molecular. 0 teor varia de 30 a 40\% dos ácidos C16 (palmítico) e C18 (esteárico) saturados e por isso apresentam um alto ponto de fusão. Exemplos: sebo, toucinho.

\section{ÁCIDOS GRAXOS ÔMEGA - 3}

São de interesse nutricional o ácido $\alpha$ - linolênico (C18:3) e seus derivados ácidos Eicosapentanóicos (C20:5) e o ácido Docosahexanóico (C22:6). Fontes de ácido $\alpha$ - linolênico são os óleos de salada, margarinas e gordura feita de óleo de canola ou de soja. Óleos de peixes e mariscos são ricos em ácidos Eicosapentanóicos e Docosahexanóico. Os ácidos graxos $\omega-3$ afetam o metabolismo lipoproteico. Os efeitos colaterais potenciais de altas doses de ácidos graxos $\omega-3$ incluem maior tempo de sangramento, infecções, diabetes, peroxidação lipídica.

\section{LIPÍDEOS COMPOSTOS}

Fosfolipídeos: 0 2o maior componente lipídico do organismo são os lipídeos em que um dos ácidos graxos é substituído por uma substância contendo fósforo, assim como o ácido fosfórico. 


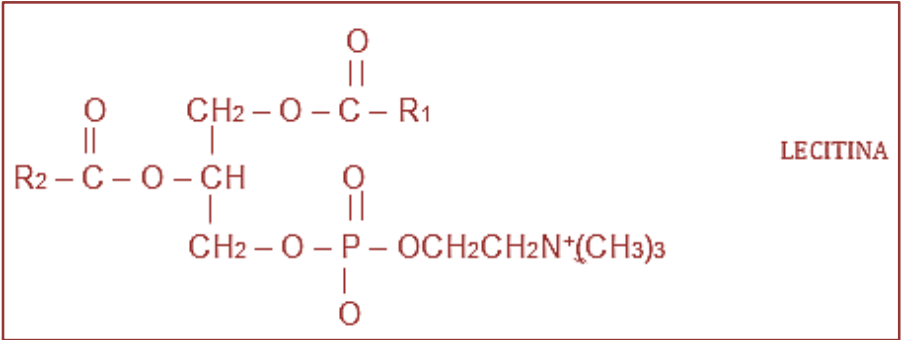

Lecitina: A lecitina (fosfatidilcolina) contém ácido fosfórico e a base colina contém nitrogênio. São encontradas grandes concentrações combinadas com proteínas nas membranas celulares, onde facilitam a passagem de gorduras para dentro e para fora da célula, e no sangue, onde também agem no transporte de lipídios (como parte de lipoproteínas). Os ácidos graxos contidos na alimentação irão influenciar os ácidos graxos que aparecem nos fosfolipídios.

1- Atua no transporte e utilização de ácidos graxos e colesterol (em lipoproteínas) através da enzima Lecitina - Colesterol Aciltransferase (LCAT).

2- A lecitina é, entre os fosfolipídeos, o mais amplamente distribuído nos alimentos. Fígado, gema de ovo, feijão de soja, amendoim, espinafre e gérmen de trigo são fontes ricas em lecitina.

3- A lecitina, porém, não é um nutriente essencial, pois o organismo produz a quantidade que é necessária. Além disso, a lecitina da alimentação é digerida antes de ser absorvida, portanto, os suplementos são de pequeno valor.

4- Devido às suas propriedades emulsificantes, a lecitina é adicionada aos produtos alimentícios. Ex: margarina, bolachas e produtos de confeitaria.

\section{OUTROS FOSFOLIPÍDEOS}

As cefalinas são semelhantes em estrutura às lecitinas. Os lipontóis contêm inositol, um composto com atividade semelhante às vitaminas. Os esfingolipideos contêm um complexo aminoálcool no lugar do glicerol. Todos eles são encontrados em altas concentrações no tecido nervoso. A esfingosina é encontrada no cérebro e outros tecidos nervosos como um componente da bainha de mielina.

Esfingosina:

Glicerol:

\begin{tabular}{|c|c|}
\hline $\mathrm{HO}-\mathrm{CH}-\mathrm{CH}=\mathrm{CH}-\left(\mathrm{CH}_{2}\right)_{12}-\mathrm{CH}_{3}$ & $\mathrm{H}_{2} \mathrm{COH}$ \\
$\mid$ & $\mathrm{I}$ \\
$\mathrm{C} \mathrm{H}-\mathrm{N}-\mathrm{H}$ & $\mathrm{H}$ \\
$\mathrm{CH}_{2}-\mathrm{O}-\mathrm{H}$ & $\mathrm{H}_{2} \mathrm{COH}$ \\
\hline
\end{tabular}

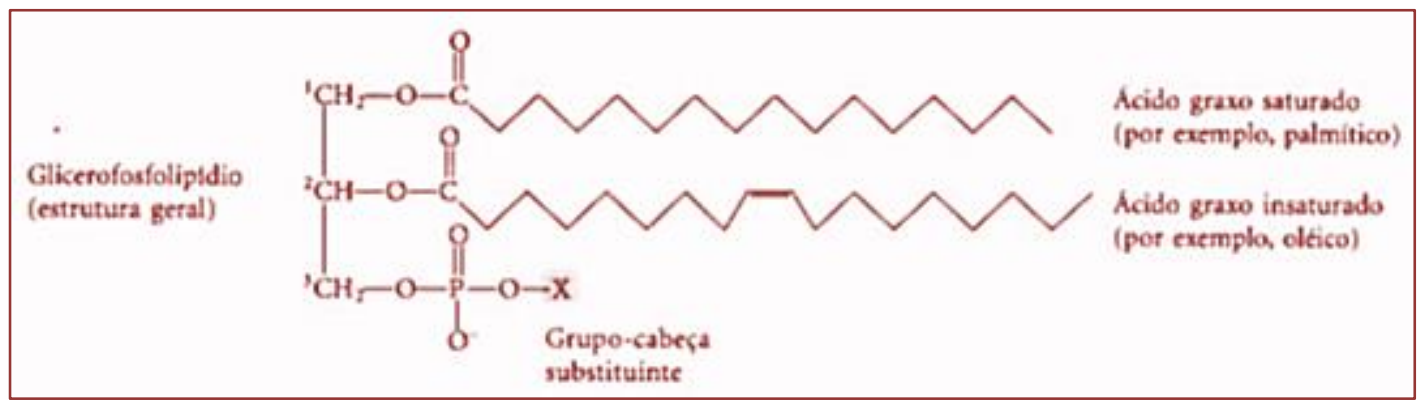




\section{GLICOLIPÍDEOS}

Incluem os cerebrosídeos e os gangliosídeos que contêm a esfingosina e uma cadeia muito longa de ácidos graxos (> 22C). 0 componente carboidrato dos cerebrosídeos é a galactose. Os gangliosídeos também contêm glicose e um composto complexo contendo um aminoaçúcar. Estruturalmente, ambos os compostos são componentes do tecido nervoso e certas membranas celulares, onde desempenham uma função no transporte de lipídeos.

\section{ESTEROIDES E ESTERÓIS}

Os esteroides constituem um grande grupo de compostos cíclicos que podem ser considerados derivados de um núcleo hidrocarbonético comum: o núcleo ciclopentanofenantreno. Os esteroides são, portanto, lipídeos de origem vegetal e animal, possuidores de um esqueleto de carbonos tetracíclico característico. São encontrados praticamente em todos os tecidos do organismo e causam uma grande variedade de efeitos fisiológicos. Os esteroides estão estruturalmente relacionados aos terpenos e são biossintetizados a partir do precursor lanosterol (um triterpeno). O lanosterol, por sua vez, provém da ciclização do esqualeno, um hidrocarboneto acíclico. Os esteroides podem ser classificados como: Esteróis; Ácidos Biliares; Hormônios Sexuais Masculinos; Hormônios Sexuais Femininos; Hormônios da Gravidez; Hormônios Adrenocorticais; Vitaminas D; Saponinas; Glicosídeos Cardíacos.

\section{ESTERÓIS}

O mais conhecido é o colesterol que está presente em todas as células animais e é particularmente abundante em tecidos nervosos. No núcleo do colesterol há oito centros de assimetria e, teoricamente, algo como 256 isômeros são possíveis. 0 colesterol é o precursor dos ácidos biliares, esteróis fecais e hormônios esteroides.

\section{COLESTEROL}

Os esteróis são caracterizados pela estrutura em anel, complexa com grupos laterais individuais. Além do colesterol, que é encontrado apenas em tecidos animais, os esteróis comuns incluem o ergosterol, que ocorre em leveduras, e $\beta$-sitosterol, que é encontrado em alimentos vegetais. O colesterol é um componente essencial das membranas estruturais de todas as células dos mamíferos. É o principal componente do cérebro e das células nervosas. É encontrado também em altas concentrações nas glândulas supra-renais, onde os hormônios adrenocorticais são sintetizados e, no fígado, onde é sintetizado e estocado. 0 colesterol é uma chave intermediária na biossíntese de uma série de esteroides importantes como: ácidos biliares, hormônios adrenocorticais (aldosterona) e hormônios sexuais (estrogênios, testosterona e progesterona). Os lipídeos sanguíneos (colesterol, triglicerídeos e fosfolipídeos) são transportados na corrente sanguínea, ligados às proteínas. Estas partículas complexas, chamadas lipoproteínas variam em composição, tamanho e densidade. As cinco classes de lipoproteínas são: Quilomícrons; Lipoproteínas de Densidade muito Baixa (VLDL); Lipoproteínas de Densidade Intermediária (IDL), Lipoproteínas de Baixa Densidade (LDL) e Lipoproteínas de Alta Densidade (HDL). Elas possuem quantidades variáveis de triglicerídeo, colesterol, fosfolipídeo e proteína. A proporção de proteína e gordura determina a densidade. As partículas com mais proteínas são mais densas, portanto, HDL tem mais proteínas do que LDL.

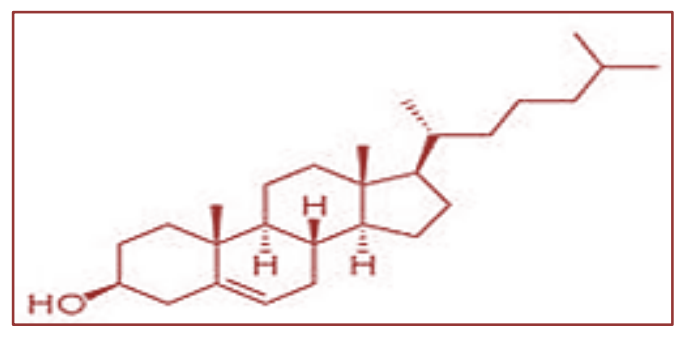




\section{COLESTEROL TOTAL}

É o colesterol contido em todas as funções de lipoproteína. Cerca de 60 a 70\% do total é carreado com LDL, 20 a $30 \%$ do total é carreado com HDL, 10 a $15 \%$ do total é carreado com VLDL. Dentre as lipoproteínas ricas em triglicerídeos estão os Quilomícrons, VLDL e quaisquer produtos remanescentes ou intermediários formados no catabolismo.

\section{REAÇõES QUÍMICAS DOS LIPÍDEOS REAÇÕES DE OXIDAÇÃO}

São as reações mais comuns em lipídeos. São causadas pelo oxigênio atmosférico, menos frequentemente pelo ozônio, peróxido, metais e outros agentes oxidantes. Essas reações ocorrem quando elétrons são removidos de um átomo ou grupo de átomos, e para cada reação de oxidação há uma reação de redução correspondente envolvendo a adição de elétrons a um átomo ou grupo de átomos.

A reação de oxidação em lipídeos é um exemplo de reação que envolve a formação de radicais livres.

\section{FATORES QUE ACELERAM A OXIDAÇÃO}

As reações de oxidação podem ser influenciadas por diversos fatores, como calor, luz, reações de ionização, traços de metais (cobre e ferro), pelas metaloproteinas e pela lipoxigenase.

1. Composição de ácidos graxos: o no , posição e a geometria das insaturações afetam a velocidade da oxidação. Para os ácidos araquidônico, linolênico, linoleico e oleico a velocidade da oxidação são aproximadamente 40:20:10:1, respectivamente. Ácido graxo cis oxida mais rapidamente que o seu isômero trans, e as ligações conjugadas são mais reativas que a não conjugada.

2. Ácido graxo livre e correspondente acilglicerol: os ácidos graxos oxidam mais rápido quando livres que na forma esterificada. A velocidade de oxidação depende do grau de instauração na molécula do ácido graxo. Assim, quanto maior o grau de instauração do óleo e, ou, da gordura, maior será a suscetibilidade à oxidação. Por exemplo, óleo de soja é muito menos estável que gordura de coco.

3. Concentração de Oxigênio: A solubilidade do oxigênio é maior em óleo do que na água. Quando o oxigênio é abundante, a velocidade da oxidação é independente de sua concentração, mas em concentração muito baixa a velocidade é aproximadamente proporcional à sua concentração. 0 oxigênio na atmosfera (21\%) coexiste com $75 \%$ de nitrogênio. Um litro de água, por exemplo, contém aproximadamente $8,0 \mathrm{mg}$ de oxigênio, o equivalente a $0,25 \mathrm{Mm}$. Portanto, a maioria dos alimentos in natura ( $80-90 \%$ de água) não tem mais que 8 ppm de oxigênio. A solubilidade do oxigênio é elevada em óleos comparada com meio aquoso.

4. Umidade: Depende da atividade de água. Em alimentos secos com baixo teor de umidade $\left(\mathrm{a}_{\mathrm{w}}<\right.$ $0,1)$, a oxidação ocorre rapidamente. Aumentando a $a_{w}$ para 0,3 retarda a oxidação de lipídeos. Este efeito protetor da pequena quantidade de água está relacionado pela redução da atividade de catalisadores metálicos, pelo amortecimento de radicais livres, e, ou, impedindo o acesso do oxigênio ao lipídeo. Em valores elevados de $\mathrm{a}_{\mathrm{w}}=0,55$ até 0,85 a velocidade da oxidação aumenta novamente, provavelmente em razão do aumento da mobilização de catalisadores e do oxigênio.

5. Tratamento térmico: A maioria das reações químicas aumenta com a elevação da temperatura e, portanto, com o tratamento térmico. Os processos que utilizam temperaturas elevadas como a pasteurização e esterilização aceleram a velocidade da reação. A refrigeração e/ou congelamento não paralisa a oxidação devido à solubilidade do oxigênio em solução aquosa aumentar em baixa temperatura.

As reações de oxidação induzidas termicamente podem ocorrer tanto em lipídeos saturados como em insaturados, em temperaturas utilizadas nos processos de frituras. Os ácidos graxos saturados são estáveis em temperaturas utilizadas em operação de enlatamento, mas nos insaturados ocorrem reações de deterioração na presença do oxigênio e calor, com formação de grande número de substâncias voláteis com sabor e odor desejáveis e indesejáveis.

6. Lipoxigenase: 0 peróxido pode também ser formado por via alternativa, pela reação de ácidos graxos polinsaturados (linoleico, linolênico e araquidônico) com o oxigênio catalisado pela enzima lipoxigenase presente em vegetais. Os radicais livres intermediários formados durante a oxidação 
catalisada pela enzima podem oxidar compostos como carotenoides e polifenois, levando à descoloração do produto.

7. Metais (ferro e cobre): Íons metálicos de transição são eficientes promotores das reações de formação de radicais livres, em razão da transferência de elétron que ocorre durante a alteração do seu estado de oxidação. Atuam de duas formas: na redução da energia de ativação da reação inicial da oxidação e na decomposição de peróxidos. 0 rompimento homolítico da fraca ligação 0-0 dos peróxidos resulta na formação de radicais livres responsáveis pela reação que ocorre em cadeia. Quantidades traços de metais são normalmente encontrados em alimentos (endógenos: livres e ligados) ou oriundos de equipamentos utilizados no processamento e armazenamento.

A ruptura homolítica espontânea em alimentos é insignificante, exceto quando estes são aquecidos durante processamento térmico. Na presença de metais, a decomposição catalítica de peróxidos é a principal fonte de radicais livres.

8. Metaloproteínas: A oxidação de lipídeos ocorre na presença de catalisadores, como as hemoproteínas, da mesma forma que a luz e o calor. A reação envolvendo hemoglobina e oxigênio produz oxigênio singlete, responsável pela oxidação; o estado de oxidação do metal é fundamental no desenvolvimento da reação.

$\mathrm{O}$ aquecimento da carne a $110^{\circ} \mathrm{C}$, por exemplo, destrói a estrutura heme, promovendo rápido desenvolvimento da rancidez. De 2 a $4 \%$ do total de gordura é encontrado na forma de fosfolipídeos altamente insaturados, sendo responsável pelo desenvolvimento da rancidez, devido à sua proximidade do grupo heme da mitocôndria.

Os pigmentos da carne, os quais atuam como potentes catalisadores, em contato com os lipídeos, na carne moída, aceleram o processo oxidativo em velocidade maior que em músculo intacto.

\section{ALTERAÇÕES QUÍMICAS}

Em alimentos in natura e/ou processados, o oxigênio é o principal agente capaz de provocar alterações como rancidez oxidativa e descoloração de carnes, frutas e vegetais. A oxidação dos constituintes do alimento (lipídeos, vitaminas, sabor e aroma) é o principal problema que afeta em todos os aspectos a qualidade do produto.

As duas alterações químicas mais importantes que ocorrem naturalmente em óleos/gorduras são as oxidações e as lipólises. A lipólise é o processo de hidrólise da ligação éster por certas enzimas (lipases) ou pela combinação do calor e da umidade, que tem como resultado a liberação de ácidos graxos, que pode ser desejável ou não à qualidade do produto. A lipólise é indesejável a alguns produtos pela formação de flavor e odor estranho (rancidez hidrolítica). No entanto, quantidade limitada de lipólise é benéfica à qualidade de alguns produtos (queijo, iogurte) pela formação de sabor e odor desejáveis.

A oxidação de lipídeos é uma das mais importantes causas da deterioração da qualidade dos alimentos, devido à formação de sabores e odores indesejáveis (rancidez oxidativa), bem como à formação de substâncias potencialmente tóxicas. Em alguns tipos de alimentos, quantidade limitada da oxidação de lipídeos é benéfica, pois leva à formação de sabor e odor desejável (queijo).

0 termo oxidação de lipídeos refere-se a uma série extremamente complexa de reações químicas, envolvendo ácidos graxos insaturados e oxigênio. Por conveniência, essas reações são divididas em 3 diferentes estágios: 
Inicial

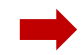

de

Propagação

Terminal
A reação inicial ocorre quando o átomo de Hidrogênio é removido do grupo metileno $\left(-\mathrm{CH}=\mathrm{CH}-\mathrm{CH}_{2}-\right.$ ) do ácido graxo insaturado, formando radical livre $\left(-\mathrm{CH}=\mathrm{CH}-\mathrm{CH}^{*}-\right.$ ). Este processo ocorre a partir de uma variedade de diferentes iniciadores presentes no alimento, incluindo peróxidos, íons metálicos de transição, luz UV e enzimas.

Uma vez formado o radical livre, este reage com o oxigênio para formar o radical peroxil $\left(-\mathrm{CH}=\mathrm{CH}-\mathrm{COO}^{*}-\right.$ ). Esses radicais são altamente reativos e capazes de remover átomos de hidrogênio de outros ácidos graxos insaturados, propagando, portanto, a reação de oxidação.

Durante a oxidação de lipídeos, diversas reações de decomposição ocorrem simultaneamente, levando à formação de misturas complexas de produtos, incluindo aldeídos, cetonas, álcoois e hidrocarbonetos. Vários desses produtos são voláteis e, portanto, contribuem com o odor característico associado à oxidação de lipídeos.

O radical livre é definido como qualquer espécie que possui um ou mais elétrons não-pareados, isto é, elétrons solitários em orbitais atômicos ou moleculares. A presença do elétron não-pareado está associada à reatividade química, uma vez que os elétrons têm a tendência a se associarem em pares. Em sistema aquoso, como encontrado em células vivas e alimentos, promove danos nas células vivas e alterações nutricionais na coloração e no flavor do alimento.

\section{A OXIDAÇÃO DE LIPÍDEOS ESTÁ ASSOCIADA À REAÇÃO DO OXIGÊNIO COM LIPÍDEOS INSATURADOS, POR MECANISMOS QUÍMICO E ENZIMÁTICO A SABER:}

Auto-oxidação: É uma reação química de baixa energia de ativação ( 4 a 5 cal/mol) bastante complexa, que abrange grande número de reações inter-relacionadas, não sendo significativamente inibida pelo abaixamento da temperatura de armazenamento do alimento. A reação envolve a formação de radicais livres e pode ocorrer na ausência da luz. Os peróxidos são os primeiros produtos formados da oxidação de óleos e gorduras insaturados. Do ponto de vista da deterioração do sabor do alimento, os peróxidos não são importantes e sim os produtos oriundos de sua decomposição: aldeídos, cetonas, álcoois, hidrocarbonetos e ácidos. As insaturações em todos os tipos de óleo e gordura representam o centro ativo pelo qual se inicia a reação de oxidação.

Foto-oxidação: Mecanismo alternativo não envolvendo a formação de radicais livres. Inicia-se pela exposição do alimento à luz na presença de certas moléculas de foto-sensores como mioglobina, riboflavina e clorofila. Na auto-oxidação e foto-oxidação, o produto intermediário formado é o peróxido. A reação de foto-oxidação é um processo oxidativo dos ácidos graxos insaturados, resultante da exposição à luz, oxigênio e foto-sensores. A presença destes nos tecidos animal e vegetal, como mioglobina, riboflavina, e clorofila, dá início ao processo de transferência de energia para a reação de formação de peróxido. É um mecanismo alternativo, independente da formação de radicais livres, porém, dependente da presença de sensores. A reação foto-oxidativa apresenta certas características que diferem da reação de auto-oxidação, a saber:

- Não envolve a formação de radicais livres

- $\quad$ É independente da pressão do oxigênio

- É inibida pela ação de receptores de oxigênio singlete, como beta-caroteno e tocoferóis, mas não é afetada pela ação de antioxidantes

- N Não apresenta período de indução (início da reação) 


\section{- Provoca mudanças na insaturação: de cis para trans}

Lipoxigenase: Esta enzima, de ocorrência em vegetal (legumes, cereais, frutas) e animal (eritrócito e leucócito) catalisa a oxigenação de alguns ácidos graxos insaturados (linoleico, linolênico e araquidônico) para seus correspondentes peróxidos, durante o armazenamento e processamento. Concentrações elevadas de lipoxigenase são encontradas em soja e ervilha e alguns tipos de feijão, enquanto amendoim e trigo possuem de 1 a $2 \%$ da quantidade encontrada na soja. A ação da enzima lipoxigenase no alimento apresenta efeitos desejáveis importantes e outros indesejáveis, resultantes da ação direta da enzima na oxidação de ácidos graxos polinsaturados (livre ou ligado), formando radicais livres. Funções desejáveis, como o branqueamento da farinha de trigo e a formação de pontes de enxofre no glúten durante a formação da massa, eliminam a necessidade de adição de oxidantes químicos, como bromato de potássio. Ações indesejáveis no alimento é a destruição de clorofila e carotenos, o desenvolvimento de sabor e odor estranhos, a oxidação de compostos como vitaminas e proteínas e a oxidação de ácidos graxos essenciais: linoleico, linolênico e araquidônico.

\section{ALTERAÇõES NA QUALIDADE DO ALIMENTO PELA AÇÃO DA LIPOXIGENASE (ENDÓGENA OU EXÓGENA)}

\section{Alteração na cor}

Branqueamento da farinha de trigo pela destruição do caroteno (desejável).

Destruição da coloração verde devida à clorofila em vegetais congelados (indesejável).

Destruição de corantes adicionados ao alimento.

\section{Alteração no flavor}

Produção de componentes voláteis responsáveis pelo aroma desejável em frutas e vegetais.

Produção de flavor estranho em vegetais congelados e em cereais armazenados.

\section{Alteração na textura}

Efeitos favoráveis nas propriedades reológicas da farinha de trigo e eventualmente na textura de produtos à base de trigo.

A oxidação do lipídeo pela ação da lipoxigenase melhora as características da massa possivelmente pela formação de pontes de enxofre envolvendo a cisteína do glúten, eliminando a necessidade do uso de oxidantes químicos (bromato de potássio).

Simultaneamente ocorre liberação do lipídeo da proteína oxidada, ajudando de alguma forma a retenção do gás durante a expansão da massa.

\section{Alterações na qualidade nutritiva}

Destruição da vitamina A e pró-vitamina A.

Destruição de ácidos graxos polinsaturados essenciais.

Interação de produtos oriundos da ação enzimática com aminoácidos essenciais na proteína, diminuindo a qualidade nutricional.

\section{RANCIDEZ HIDROLÍTICA}

Durante o armazenamento de alimentos, a fração lipídica presente é lentamente hidrolisada pela água à temperatura elevada (processo físico), ou por enzimas lipolíticas naturais ou produzidas por bactérias e fungos contaminantes, contribuindo para a rancificação hidrolítica do alimento.

Os ácidos graxos de 14 a 22 carbonos liberados são sensorialmente inativos, mas ácidos graxos contendo de 4 a 10 átomos de carbono conferem típico off-flavor em alimentos ou atuam como precursores de outras substancias de flavor ativo. Por exemplo, os ácidos octanóico, decanóico e dodecanóico produzidos pela hidrólise das gorduras de coco e dendê conferem sabor de sabão a produtos de confeitaria. 0 limiar de percepção em água dos ácidos butírico $\left(\mathrm{C}_{4}\right)$, capróico $\left(\mathrm{C}_{6}\right)$, caprílico $\left(\mathrm{C}_{8}\right)$, cáprico $\left(\mathrm{C}_{10}\right)$, láurico $\left(\mathrm{C}_{12}\right)$ é de 0,5 a 10,0 ppm. 


\section{CAPÍTULO 04 Proteínas}

O nome "proteína" é de origem grega e significa "de primeira importância". Em sua composição estão presentes $\mathrm{C}, \mathrm{H}$ e 0 . As proteínas também contêm aproximadamente $16 \%$ de $\mathrm{N}$, juntamente com $\mathrm{S}$ e, algumas vezes, outros elementos, tais como fósforo (P), ferro (Fe) e cobalto (Co). Os vegetais sintetizam a proteína a partir do $\mathrm{N}$, que obtêm a partir de nitratos e amônia do solo e, nas circunstâncias únicas das leguminosas, os nitratos se tornam disponíveis simbioticamente a partir do $\mathrm{N}_{2}$ atmosférico pelas bactérias nos nódulos das raízes. Já os animais obtêm o $\mathrm{N}$ que necessitam de alimentos proteicos seja de origem vegetal ou animal. $\mathrm{O}$ metabolismo animal, a excreção e morte finalmente fazem retornar o $\mathrm{N}_{2}$ ao solo numa continuação do ciclo do nitrogênio.

\section{ESTRUTURA E CLASSIFICAÇÃO}

A base da estrutura da proteína são os aminoácidos, dos quais 20 foram reconhecidos como constituintes da maioria das proteínas. Eles são compostos que apresentam em sua molécula um grupo amino $\left(-\mathrm{NH}_{2}\right)$ e um grupo carboxila (-COOH). Apenas a Prolina, possui um grupo imino (-NH-) ao invés do grupo amino. Em pH fisiológico, esses grupos estão na forma ionizada: $-\mathrm{NH}_{3}{ }^{+},-\mathrm{COO}^{-} \mathrm{e}-\mathrm{NH}_{2}{ }^{+}-$. Os aminoácidos têm uma fórmula básica comum, na qual os grupos amino e carboxila estão ligados ao carbono $\alpha$, ao qual também se liga um átomo de hidrogênio e um grupo variável chamado cadeia lateral ou grupo R. É a estrutura da cadeia lateral $\mathrm{R}$ que diferencia os aminoácidos entre si.

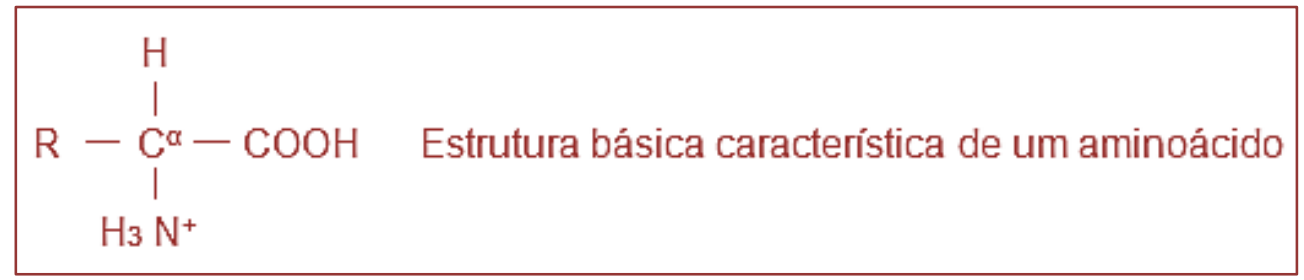

Os aminoácidos se combinam para formar proteínas através de uma ligação chamada peptídica que une os carbonos carboxílicos de um aminoácido ao $\mathrm{N}$ de outro. 0 composto resultante tem um grupo carboxila livre em uma das pontas e um grupo amino livre na outra, possibilitando a cadeia a continuar se ligando a outros aminoácidos em qualquer das pontas. As proteínas variam no tamanho, como, por exemplo, de polipeptídeos relativamente pequenos, como a Adrenocorticotropina (ACTH) com 23 unidades de aminoácidos até moléculas muito complexas com várias centenas de milhares de unidades de aminoácidos.

Os polipeptídeos que constituem a Estrutura Primária das proteínas podem conter de poucas até 300 unidades de aminoácidos. Muitas cadeias de polipeptídeos podem ser ligadas entre si, normalmente através de ligações S - S da cistina, em uma forma helicoidal, pregueada ou espiral randômica chamada de Estrutura Secundária. As proteínas mais complexas se caracterizam por uma Estrutura Terciária ${ }_{\llcorner}$na qual a cadeia polipeptídica está enrolada sobre si mesma em uma forma globular, com toda a estrutura sendo presa rigidamente por forças interatômicas, tais como ligações de hidrogênio. As extensas possibilidades de variação oferecidas por estas estruturas resultam em milhões de proteínas diferentes com propriedades e funções biológicas específicas.

As proteínas existem nas formas fibrosa e globular. As Proteinas Fibrosas caracterizam-se por várias cadeias peptídicas helicoidais torcidas juntas para formar uma haste rija. São caracterizadas por baixa solubilidade e alta força mecânica. Aparecem em elementos estruturais, tais como colágeno do tecido conjuntivo, queratina do cabelo e unhas e miosina do tecido muscular. As Proteinas Globulares são 
encontradas em líquidos teciduais. São muito solúveis e facilmente desnaturadas. As Proteínas Globulares de interesse na nutrição são: a caseína, presente no leite, a albumina presente no ovo, na carne etc. Proteínas Simples são aquelas que produzem apenas aminoácidos a partir da hidrólise. Incluem albuminas, globulinas, prolaminas entre outras. As proteínas que são solúveis em $\mathrm{H}_{2} \mathrm{O}$, tais como as albuminas e globulinas, estão presentes nos líquidos animais enquanto que as menos solúveis, tais como a miosina e a proteína muscular, estão presentes nos tecidos. Proteínas Conjugadas são combinações nas quais uma substância não proteica está ligada a uma molécula de proteína simples, como um grupo prostético, assim facilitando as funções que nem os próprios constituintes poderiam provavelmente realizar. As proteínas conjugadas incluem as Nucleoproteínas encontradas no Ácido Ribonucleico (RNA) e Ácido Desoxirribonucleico (DNA). As Mucoproteinas e as Glicoproteinas são aquelas que combinam proteínas com quantidades variáveis de Polissacarídeos Complexos, tais como Mucina presente nas secreções gástricas, Lipoproteinas presentes no plasma sanguíneo, Fosfoproteinas que contêm $\mathrm{H}_{3} \mathrm{PO}_{4}$ ligado à proteína por ligações éster, tal como na caseína do leite; Metaloproteinas, tais como ferritina e a hemossiderina nas quais metais como $\mathrm{Fe}^{++}, \mathrm{Cu}^{++}$e $\mathrm{Zn}^{++}$estão ligados às proteínas. Proteínas Derivadas: Proteoses, Peptonas e Peptídeos formam-se nos vários estágios do metabolismo proteico.
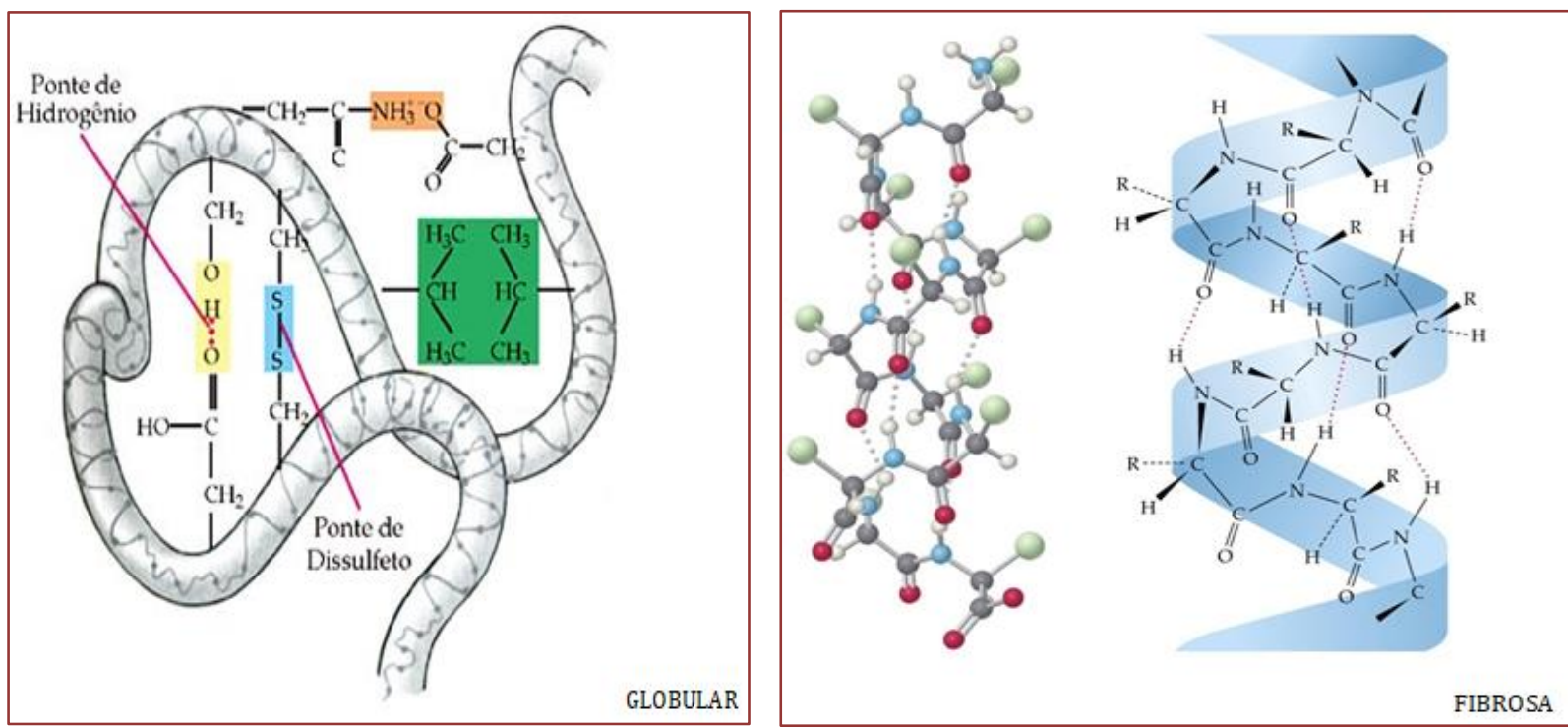

\section{HIPERTEXTO}

Fonte: Champe, 2009

\section{LEGUMINOSAS COMO FONTES DE PROTEÍNAS}

As leguminosas são únicas no reino vegetal por causa de suas sementes, ricas em proteínas e pobres em amido, diferente das sementes de grãos de cereais, que são pobres em proteínas e ricas em amido. 0 seu conteúdo de Aminoácidos Essenciais é mais parecido com o das proteínas animais. Suplementadas com uma pequena quantidade de metionina dos cereais ou fontes animais, o seu padrão de aminoácido é adequado para suportar tanto a vida quanto o crescimento nos humanos. Os feijões de soja são únicos pelo fato de que um produto de seu processamento, a proteína da soja isolada, é a proteína com um padrão de aminoácido capaz de suportar a vida e o crescimento. Esta característica extraordinária é talvez a consequência casual de uma habilidade rara dos vegetais leguminosos de fixar o $\mathrm{N}$ gasoso do ar para o seu uso. Na realidade, o vegetal por si mesmo não tem esta capacidade e, como todos os outros vegetais, deve retirar o $\mathrm{N}$ através das raízes ou na forma de nitrato de íons de amônio. Entretanto, localizadas nos nódulos das raízes de leguminosas estão as bactérias Rhizobium, que fixam o $\mathrm{N}$ da atmosfera. Numa relação simbiótica, as bactérias fornecem o $\mathrm{N}$ na forma de aminoácido e amidas em troca da energia fornecida pelo vegetal através da fotossíntese.

\section{DESNATURAÇÃO DE PROTEINAS}

A estrutura tridimensional de uma proteína é significativa para a sua função. As ligações que mantêm a forma tridimensional são relativamente fracas e facilmente rompidas por agitação mecânica, extremos de temperatura, acidez ou alcalinidade. Quando isso ocorre, a proteína perde sua forma, característica e não é 
mais capaz de desempenhar sua função neste papel particular. Este desemaranhamento irreversível da molécula de proteína, chamado desnaturação, é um evento que normalmente é prejudicial e algumas vezes desastroso para o organismo, dependendo de quantas moléculas de proteína são afetadas. Enquanto um ovo está fritando, a clara do ovo gradualmente engrossa e fica branca conforme a proteína é desnaturada pelo calor. Do mesmo modo, uma queimadura severa desnatura e, assim, destrói a proteína na pele e vasos sanguíneos. Na realidade é a suscetibilidade das proteínas ao excesso não moderado de calor, frio, ácido e álcalis que determina a limitação ambiental na qual os humanos podem sobreviver e funcionar.

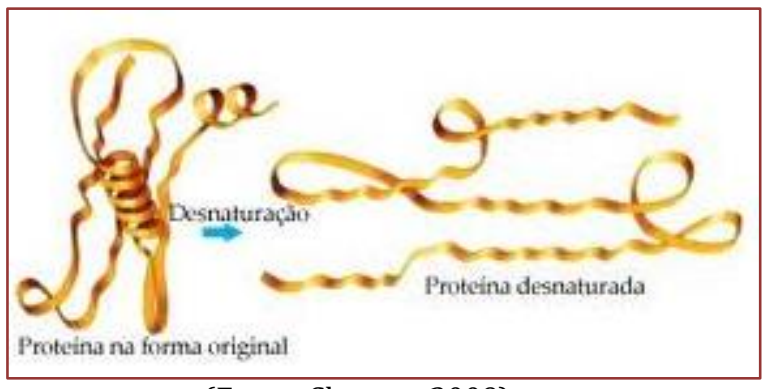

(Fonte: Champe, 2009)

\section{FUNÇÕES DAS PROTEÍNAS}

As proteínas da dieta estão envolvidas na síntese das proteínas teciduais e outras funções metabólicas especiais; nos processos anabólicos, fornecendo os aminoácidos necessários para a construção e manutenção dos tecidos orgânicos; como uma fonte de energia, as proteínas são equivalentes aos carboidratos no fornecimento de $4 \mathrm{Kcal} / \mathrm{g}$. Entretanto, são consideravelmente mais caras, tanto em custo quanto na quantidade de energia necessária para o metabolismo. As proteínas desempenham um papel estrutural não apenas em todos os tecidos do corpo, mas também na formação de enzimas, hormônios e de vários líquidos e secreções corpóreas. Como anticorpos, as proteínas estão envolvidas na função do sistema imunológico. Na forma de proteínas participam do transporte de triglicerídeos, colesterol, fosfolipídeos e vitaminas lipossolúveis. Muitas vitaminas e minerais são ligados a carreadores proteicos específicos para o transporte. A albumina transporta ácidos graxos livres e bilirrubina, assim como muitas drogas. As proteínas também contribuem para a homeostase através da manutenção de relações osmóticas normais entre os líquidos corpóreos, como é evidenciado pela formação de edema como uma consequência de hipoproteinemia. A albumina é particularmente importante para esta função. Devido a sua estrutura única, as proteínas são capazes de se combinar ou com substâncias ácidas ou com substâncias básicas, mantendo assim o equilíbrio ácido-base do sangue e tecidos.

\section{ENZIMAS COMO PROTEÍNAS}

$\mathrm{O}$ fato de todas as enzimas serem proteínas e suscetíveis à desnaturação é significante para as necessidades ambientais do organismo humano. As enzimas funcionam por se ligarem a moléculas de formas e tamanhos_característicos. Sendo assim a importância da manutenção da forma original de uma enzima em particular é imprescindível. Como a desnaturação muda a forma das enzimas tornando-as não funcionais, a maioria dos organismos vivos não pode tolerar extremos de temperatura e pH. Algumas exceções são formas diminutas de vegetais que sobrevivem a temperaturas próximas da fervura de verões quentes ou no ambiente frio de bancos de neve. Devido às exigências rígidas da função enzimática de um pH ótimo, existe uma série de mecanismos para eliminar o excesso de materiais ácidos ou alcalinos do sangue. Exemplo fisiológico da desnaturação de enzima é o efeito do ácido láctico que se acumula durante exercícios vigorosos, alcançando, eventualmente, um nível suficiente para interferir com a ação enzimática normal, contribuindo para a resultante fadiga.

As enzimas em alimentos não cozidos são desnaturadas pelo ácido clorídrico (HCl) do estômago. A papaína (enzima da papaia) é rapidamente desnaturada conforme a temperatura da carne sobe durante o cozimento. Se não for destruída desta maneira, é mais tarde desnaturada e parcialmente digerida quando atinge o estômago. 0 mesmo fato ocorre com enzimas que são tomadas oralmente como suplemento. Neste caso, entretanto, as enzimas são empacotadas em cápsulas que não dissolvem até que alcancem o intestino delgado. 


\section{AMINOÁCIDOS ESSENCIAIS (AAE) E NÃO ESSENCIAIS}

Aminoácidos Essenciais (AAE) são aqueles em que a síntese do organismo não é suficiente para suprir as necessidades metabólicas e, sendo assim, precisam ser fornecidos como uma parte da dieta. São eles: treonina, valina, triptofano, isoleucina, lisina, leucina, fenilalanina, metionina, histidina e arginina. A ausência ou a ingestão inadequada de qualquer um desses aminoácidos leva a um balanço de $\mathrm{N}$ negativo, perda de peso, crescimento prejudicado em bebês e crianças e sintomas clínicos. Os aminoácidos não essenciais remanescentes, como alanina, ácido aspártico, asparagina, ácidotglutâmico, glutamina, glicina, prolina e serina são igualmente importantes para a estrutura da proteína. Entretanto, se quantidades adequadas de certos aminoácidos não essenciais não estiverem presentes na hora da síntese da proteína, podem ser sintetizados a partir de AAE ou de precursores de $\mathrm{C}$ e N, apropriados prontamente sintetizados na célula. Os aminoácidos condicionalmente essenciais são aqueles que se tornam essenciais sob certas circunstâncias clínicas, como p. ex: taurina, cisteína e, possivelmente, tIrosina são tidos como condicionalmente essenciais nos bebês prematuros.

\section{FUNÇõES ESPECIAIS DOS AA}

Quase todos os aminoácidos têm certas funções únicas no organismo. 0 Triptofano, o aminoácido mais complexo, é um precursor da vitamina Niacina e do neurotransmissor Serotonina. A Metionina é o principal doador de grupos metila para a síntese de compostos tais como Colina e Carnitina. Também é um precursor da Cistina e de muitos outros compostos que contêm enxofre. A Fenilalanina é um precursor da Tirosina e juntas levam à formação de Tiroxina e Epinefrina. A Tirosina é o precursor do qual são feitos o pigmento da pele e do cabelo. A Arginina e a Citrulina estão envolvidas especificamente na síntese de Ureia no fígado. A Glicina, o mais simples e mais ubíquo dos aminoácidos, se combina com muitas substâncias tóxicas, convertendo-a em formas inócuas que são então excretadas. Também é usada na síntese do núcleo Porfirina da hemoglobina e é um constituinte de um dos ácidos da bile (ácido glutâmico). A Histidina é essencial para a síntese de Histamina, que causa vasodilatação no sistema circulatório. A Creatinina, sintetizada a partir da Arginina, Glicina e Metionina, se combina com o fosfato para formar a fosfocreatinina, um importante reservatório de fosfato de alta energia na célula.

A Glutamina, formada pelo ácido glutâmico, e a Asparagina, formada a partir do ácido aspártico, têm importantes papéis como reservatórios de grupos amino por todo o corpo. A Glutamina tem recebido atenção recentemente como uma fonte primária de combustível para o trato intestinal, especialmente no controle da síntese de glicogênio e degradação proteica, assim como para manter a integridade contra transformação bacteriana. É o aminoácido mais abundante no plasma e no músculo esquelético. 0 ácido glutâmico é um precursor do neurotransmissor Ácido Gama-Amino-Butírico (GABA).

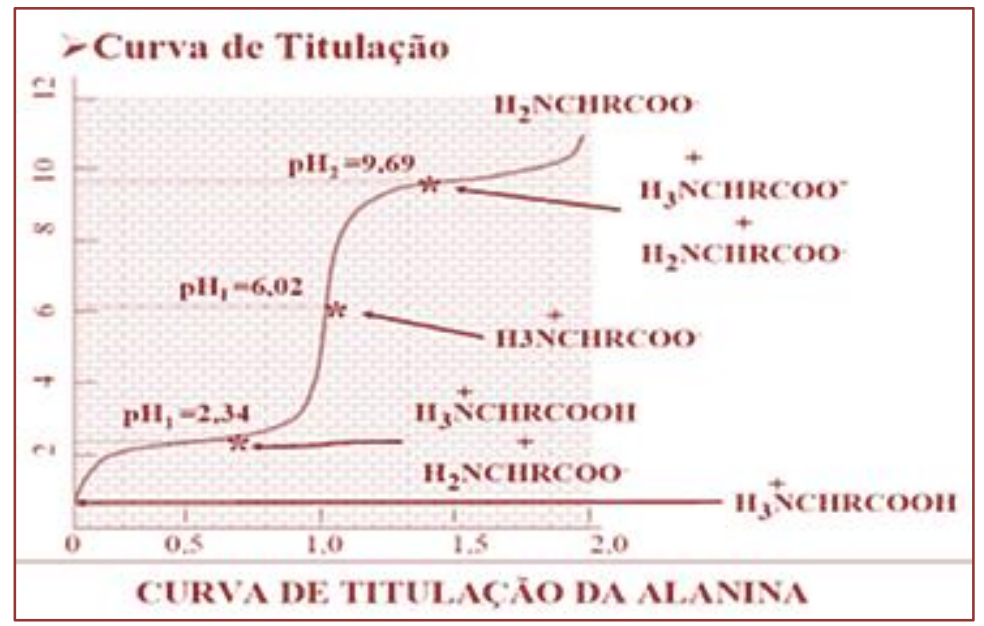

(Fonte: Champe, 2009)

A curva de titulação da alanina mostra a dissociação independente de seus dois grupos funcionais: o grupo $\alpha$-amino e o grupamento $\alpha$-carboxila.

A curva de titulação da esquerda para a direita ilustra mudança do estado de ionização da alanina, assim como é descrito da direita para a esquerda na reação abaixo: 
Conforme os prótons vão sendo removidos da molécula, eles são primeiramente removidos do grupo carboxila, já que esse tem o menor $\mathrm{pK}(\mathrm{pKa}=2,3)$. Quando o $\mathrm{pH}$ aumenta em direção ao $\mathrm{pK}$ do grupamento amina $(\mathrm{pKa}=9,9)$, esse então perde seus prótons. Cada pKa representa o ponto médio de dois equilíbrios, ilustrando que os aminoácidos (e proteínas) têm capacidade de tamponamento.

No $\mathrm{pH}$ 7,0, as cadeias laterais ionizáveis de aminoácidos em proteínas apresentam cargas características:

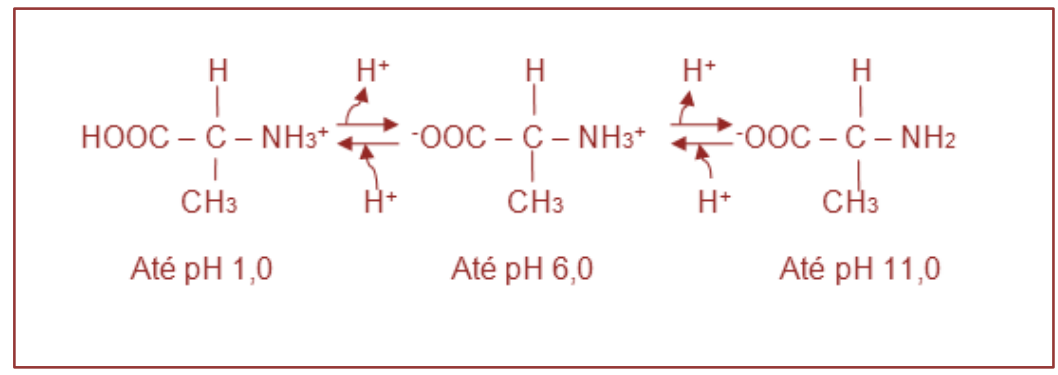

- Carregadas positivamente: lisina, arginina.

- Carregadas negativamente: aspartato, glutamato.

- A histidina torna-se carregada positivamente se $\mathrm{pH}$ for inferior a 6,0.

- $\quad$ A cisteína torna-se carregada negativamente se pH for maior que 8,0.

\section{pH Isoelétrico}

0 total de cargas de um aminoácido ou de uma proteína equivale à soma de todas as cargas das cadeias laterais de cada aminoácido. $\mathrm{O}$ valor do $\mathrm{pH}$ que produz um total de carga igual a zero (neutra) na molécula é denominado $\mathrm{pH}$ isoelétrico, ou pI.

- $\quad$ Se o $\mathrm{pH}>$ que $\mathrm{pI}$, o total de cargas no aminoácido (ou proteína) será negativo.

- $\quad$ Se o $\mathrm{pH}<$ que pI, o total de cargas no aminoácido (ou proteína) será positivo.

As proteínas não se deslocam em um campo elétrico quando o $\mathrm{pH}$ do sistema tampão é igual ao seu ponto isoelétrico, pois elas não possuem carga para serem atraídas para o catodo ou para o anodo.

\section{SOLUBILIDADE DAS PROTEÍNAS}

A água associada com proteínas pode assumir diferentes formas. A água constitucional e vicinal, localizada no interior da molécula proteica ou fortemente adsorvida em sítios superficiais específicos representa cerca de $0,3 \mathrm{~g} / \mathrm{g}$ de proteína seca. A água que ocupa os sítios das camadas superficiais remanescentes ou das camadas adjacentes às proteínas pode representar um acréscimo de mais de 0,3 g de água/g de proteína seca.

As proteínas interagem com a água através dos átomos que participam das ligações peptídicas (dipolodipolo ou pontes de hidrogênio) ou através das cadeias laterais de seus aminoácidos (interações com grupos polares).

A solubilidade das proteínas em meio aquoso é resultante de vários parâmetros como $\mathrm{pH}$, força iônica e temperatura. Para ser solúvel uma proteína deve ser capaz de interagir tanto quanto possível com o solvente (por pontes de hidrogênio, dipolo-dipolo e interações iônicas).

\section{CLASSIFICAÇÃO DAS PROTEÍNAS EM FUNÇÃO DA SOLUBILIDADE}

De acordo com a solubilidade em diversos solventes, as proteínas podem ser classificadas em:

- Albuminas: Solúveis em água e coagulam pelo calor. Ex: ovoalbumina e lactoalbumina. 
- Globulinas: Pouco solúveis ou insolúveis em água. Coagulam pelo calor. São solúveis em soluções salinas diluídas em pH 7,0. Ex: miosina, ovoglobulina e lactoglobulina.

- Prolaminas: Insolúveis em água e em soluções salinas e solúveis em soluções de etanol. Ex: gliadina (trigo e centeio), zeína (milho).

- Glutelinas: Insolúveis em água, soluções salinas e de etanol. Solúveis em soluções ácidas e alcalinas diluídas. São encontradas somente em vegetais. Ex: glutelina (trigo).

- Escleroproteínas: Proteínas de estrutura fibrosa, insolúveis nos solventes anteriormente mencionados. Ex: colágeno e queratina.

\section{DESNATURAÇÃO DE PROTEÍNAS}

A conformação de uma proteína é frágil e em função disso tratamentos das proteínas com ácidos, alquilas, soluções salinas concentradas, solventes, calor e radiações podem alterar essa conformação.

A desnaturação de uma proteína é qualquer modificação na sua conformação (alteração das estruturas secundária, terciária ou quaternária) sem o rompimento das ligações peptídicas envolvidas na estrutura primária.

Os efeitos da desnaturação são numerosos, entre os principais podem ser citados:

- Redução da solubilidade devido ao aumento da exposição de resíduos hidrofóbicos.

- Mudança na capacidade de ligar água.

- Perda da atividade biológica (ex: enzimática ou imunológica).

- $\quad$ Aumento da suscetibilidade ao ataque por proteases devido à exposição das ligações peptídicas.

- $\quad$ Aumento da viscosidade intrínseca.

- Dificuldade de cristalização.

- Aumento da reatividade química.

A desnaturação pode ser reversível ou irreversível. A sensibilidade de uma proteína à desnaturação depende das ligações que estabilizam sua conformação, da intensidade e do tipo de agente desnaturante.

Os agentes de desnaturação podem ser classificados em físicos (calor, frio, irradiação, ultravioleta, ultrassom, agitação, etc.) e químicos (alterações de pH, solventes, ureia, etc.).

A desnaturação por esses diferentes agentes pode conduzir a estados estruturais diferentes. Por exemplo, a desnaturação completa pelo calor é, em regra, irreversível, porém a desnaturação por ureia é, comumente reversível, ou seja, a remoção da ureia permite a regeneração da proteína à forma nativa.

\section{AGENTES FÍSICOS}

O calor é o agente físico mais comum, responsável pela alteração conformacional de proteínas. A velocidade de desnaturação depende da temperatura. Para a maioria das reações químicas, o aumento da velocidade é de cerca de 2 vezes para cada aumento de $10^{\circ} \mathrm{C}$ na temperatura. Entretanto, no caso da desnaturação proteica, essa velocidade pode aumentar 600 vezes quando a temperatura é elevada em $10^{\circ} \mathrm{C}$ acima da temperatura de desnaturação. Isso é devido ao baixo nível de energia envolvido nas interações que estabilizam as estruturas secundária, terciária e quaternária.

A suscetibilidade de proteínas à desnaturação pelo calor depende de vários fatores, tais como a natureza da proteína, concentração proteica, atividade de água, pH, força iônica e o tipo de íons presentes. Essa desnaturação é frequentemente seguida de uma redução na solubilidade, devido a exposição dos resíduos hidrofóbicos e a agregação das moléculas de proteínas desenroladas.

Temperaturas entre 50 e $100^{\circ} \mathrm{C}$ provocam vibrações e perturbações que rompem as pontes de hidrogênio e de interações de Van der Waals, assim como as ligações polares lançando grupamentos uns contra os outros de forma aleatória podendo causar desnaturação irreversível. 
O uso de temperaturas entre $-10^{\circ} \mathrm{C}$ e $-40^{\circ} \mathrm{C}$ também pode provocar desnaturação irreversível de algumas proteínas. Algumas enzimas, entretanto, não se desnaturam e conservam sua atividade a temperaturas de $-40^{\circ} \mathrm{C}$, como $\alpha$-galactosidase.

\section{QUANTO MAIS RÁPIDO FOR O CONGELAMENTO MENOS DESNATURANTE É O PROCESSO}

Tratamentos mecânicos muito severos (ex: batimento) podem desnaturar as proteínas. Também altas pressões, radiação eletromagnética, radiação ultravioleta e radiações ionizantes podem provocar mudanças na conformação, ruptura de ligações covalentes, ionização, formação de radicais proteicos livres em função do nível de energia.

\section{AGENTES QUÍMICOS}

A desnaturação por meios químicos envolve rompimento ou formação de ligações covalentes e é geralmente irreversível. As reações mais usuais são as de oxidação ou redução que agem sobre os grupos $\mathrm{SH}$ e -s-s-, respectivamente.

0 pH do meio exerce uma forte influência no processo de desnaturação. A maioria das proteínas é estável em uma faixa característica de $\mathrm{pH}$, mas se expostas em valores extremos $(>10,0 \mathrm{ou}<3,0)$ as proteínas normalmente desnaturam. Em alguns casos quando a mudança não é muito brusca o retorno ao $\mathrm{pH}$ original renatura a proteína.

A maioria dos solventes orgânicos pode atuar como agentes desnaturantes.

\section{PROPRIEDADES FUNCIONAIS DE PROTEÍNAS}

A qualidade de um alimento é definida pela sua composição, suas propriedades nutricionais e suas propriedades funcionais. As propriedades funcionais de um ingrediente são as que determinam sua utilização. Propriedades funcionais de proteínas são definidas como as propriedades físico-químicas que afetam seu comportamento em sistemas alimentares durante o preparo, processo, armazenamento, consumo, e contribuem para a qualidade e para atributos sensoriais dos alimentos.

As propriedades funcionais das proteínas alimentícias podem ser classificadas em 3 grupos principais:

[1] Propriedades de Hidratação: dependem das interações entre água e as proteínas. Compreendem propriedades como adsorção e retenção de água, formação de gel, adesividade, dispersibilidade, solubilidade e viscosidade.

[2] Propriedades relacionadas com interações proteínas-proteínas: a este grupo pertencem propriedades como: formação de gel, coagulação, formação de estruturas como fibras e glúten.

[3] Propriedades de superfície: emulsificação, formação de espumas, formação de películas.

Essas propriedades não são totalmente independentes umas das outras. A formação de gel não envolve apenas interações tipo proteína-proteína, mas também água-proteína. A viscosidade e a solubilidade dependem tanto das interações água-proteína como proteína-proteína. Todas as propriedades funcionais estão relacionadas com a hidrofilicidade e/ou hidrofobicidade das proteínas, e estas, por sua vez, dependem dos teores de aminoácidos apolares, polares, e carregados, da massa molar, da estrutura e da conformação da proteína, entre outros fatores.

Tabela - Propriedades funcionais de proteínas requeridas em vários alimentos

\begin{tabular}{|l|l|}
\hline \multicolumn{1}{|c|}{ Alimento } & \multicolumn{1}{c|}{ Funcionalidade } \\
\hline Bebidas & Solubilidade em diversos valores de pH, estabilidade térmica, viscosidade \\
\hline Sopas, molhos & Viscosidade, emulsificação, retenção de água \\
\hline Produtos de Panificação & $\begin{array}{l}\text { Formação de uma matriz e um filme com propriedades viscoelásticas, coesão, } \\
\text { desnaturação térmica, formação de gel, absorção de água, emulsificação, } \\
\text { aeração. }\end{array}$ \\
\hline $\begin{array}{l}\text { Derivados de leite (sorvetes, } \\
\text { iogurtes) }\end{array}$ & $\begin{array}{l}\text { Emulsificação, retenção de gordura, viscosidade, aeração, formação de gel, } \\
\text { coagulação }\end{array}$ \\
\hline Substitutos de ovos & Aeração, formação de gel \\
\hline
\end{tabular}




\begin{tabular}{|l|l}
$\begin{array}{l}\text { Produtos cárneos } \\
\text { (embutidos, presunto) }\end{array}$ & $\begin{array}{l}\text { Emulsificação, gelificação, coesão, absorção de água e gordura, retenção de } \\
\text { água. }\end{array}$ \\
\hline
\end{tabular}

\section{CAPÍTULO 05 Enzimas}

Quase todas as enzimas conhecidas são PROTÉ́NAS, (com exceção de moléculas de RNA que agem como enzimas, catalisando processos). A catálise é a atividade mais importante das enzimas. São catalisadores de sistemas biológicos, dispositivos moleculares que determinam o perfil de transformações químicas e participam na transformação de diferentes formas de energia. Na ausência de catálise, a maioria das reações nos sistemas biológicos ocorreria de forma extremamente lenta para fornecer produtos necessários ao metabolismo de um organismo.

\section{CARACTERÍSTICAS MAIS IMPORTANTES}

\section{Poder catalítico}

As enzimas aceleram as reações por fatores de 1.000.000 vezes, ou como catalisadores aumentam de várias ordens de grandeza a velocidade das reações que catalisam.

\section{Especificidade}

Por serem altamente específicas, as enzimas "selecionam", entre todas as reações potencialmente possíveis, aquelas que efetivamente irão ocorrer. A especificidade das enzimas chega ao ponto de distinguir estereoisômeros de um determinado composto.

\section{INTERAÇÃO ENZIMA - SUBSTRATO}

As enzimas são macromoléculas proteicas. Embora o total da molécula enzimática seja necessário para o papel catalítico, a ligação com o substrato dá-se apenas em uma região pequena e bem definida da enzima. Esta região chama-se Centro Ativo ou Sítio Ativo da Enzima.

0 Centro Ativo é formado por resíduos de aminoácidos, trazidos à proximidade uns dos outros pelos dobramentos da cadeia polipeptídica que definem a estrutura terciária da proteína. 0 centro ativo, assim organizado, constitui uma cavidade em forma definida que permite à enzima "reconhecer" seu substrato.

De fato, uma molécula, para ser aceita como substrato, deve ter a forma espacial adequada para alojar-se no centro ativo e grupos químicos capazes de estabelecer ligações precisas com os radicais do centro ativo. 
Classificação das Enzimas e os Tipos de Reações que Catalisam

\begin{tabular}{|c|c|}
\hline Classe & Tipo de Reação \\
\hline 1.Óxido-Redutases & $\begin{array}{l}\text { Óxido-Redução } \\
\mathrm{AH}_{2}+\mathrm{B} \stackrel{\mathrm{A}+\mathrm{BH}_{2}}{\rightleftarrows}\end{array}$ \\
\hline 2. Transferases & $\begin{array}{l}\text { Transferência de Grupos } \\
\mathrm{A}-\mathrm{X}+\mathrm{B}\end{array}$ \\
\hline 3. Hidrolases & $\begin{array}{l}\text { Hidrólise } \\
\mathrm{A}-\mathrm{B}+\mathrm{H}_{2} \mathrm{O} \rightleftarrows \mathrm{A}-\mathrm{H}+\mathrm{B}-\mathrm{OH}\end{array}$ \\
\hline 4. Liases & $\begin{array}{l}\text { Adição de grupos a duplas ou remoção de grupos deixando } \\
\text { duplas. } \\
\text { A-B } \rightleftarrows \mathrm{A}=\mathrm{B}+\mathrm{X}-\mathrm{Y}\end{array}$ \\
\hline 5. Isomerases & 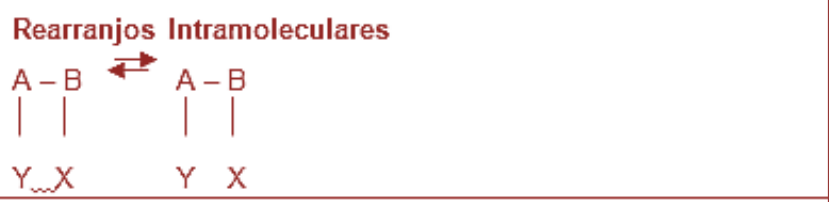 \\
\hline 6. Ligases & $\begin{array}{l}\text { Condensação de duas moléculas, associada à hidrólise de } \\
\text { uma ligação de alta energia (em geral, do ATP) } \\
\mathrm{A}+\mathrm{B} \text { A-B }\end{array}$ \\
\hline
\end{tabular}

Fonte: Marzzoco; Torres, 1999

\section{EXEMPLOS DE ESPECIFICIDADE DAS ENZIMAS}

Enzimas Proteolíticas são específicas para hidrólise de proteínas. A pepsina é uma enzima proteolítica que hidrolisa ligações peptídicas dos quais participam grupos carboxílicos de aminoácidos aromáticos como Triptofano, Fenilalanina e Tirosina, enquanto a tripsina é uma enzima proteolítica que reconhece apenas ligações peptídicas formadas por arginina ou lisina. Graus extremos de especificidade são encontrados entre as enzimas L-aminoxidases, que são capazes de reconhecer isômeros na configuração L, sendo inativas para os aminoácidos na forma D.

\section{PH E TEMPERATURA NA ATIVIDADE ENZIMÁTICA}

A maioria das enzimas apresenta um valor de $\mathrm{pH}$ para o qual a sua atividade é máxima. A velocidade da reação diminui à medida que o $\mathrm{pH}$ se afasta desse valor ótimo, que é característico para cada enzima. $\mathrm{O} \mathrm{pH}$ ótimo depende do no e tipo de grupos ionizáveis que a enzima apresenta, e da sequência em que estão organizados, ou seja, depende da sua estrutura primária. A eficiência da catálise depende de encontraremse, enzima e substrato com conformação e carga adequadas para permitir a interação. Com relação à Temperatura:

A $0^{\circ}$ C: a velocidade da reação enzimática é próxima de zero. Aumentando-se a temperatura, há aumento de velocidade, porém isto só ocorre enquanto a enzima conservar sua estrutura original.

Acima de 50ำ - 55ํㅡ: a maioria das proteínas globulares (enzimas também) são desnaturadas, havendo alterações nas moléculas e havendo também perda do poder de catálise.

\section{CATALASE E PEROXIDASE}

Frutas e vegetais armazenados, mesmo à temperatura de congelamento, podem deteriorar-se em razão da presença de certas enzimas. Consequentemente, os vegetais e algumas frutas, para serem preservados por enlatamento, congelamento ou desidratação, são, em sua maioria, branqueados para inativar as enzimas.

As enzimas catalase e peroxidase ocorrem em plantas, animais e microrganismos e são utilizadas para testar a eficiência do branqueamento de frutas e vegetais antes de seu congelamento e armazenamento. 
Ambas possuem o grupo prostético ferriprotoporfirina $\left(\mathrm{Fe}^{+++}\right)$sendo um grupo prostético em peroxidase e quatro em catalase, os quais influenciam as reações químicas catalisadas por estas enzimas.

\section{ATUAÇÃO DAS ENZIMAS NA CINÉTICA DAS REAÇÕES}

As enzimas atuam na cinética das reações acelerando a velocidade da reação por diminuir sua energia de ativação. A velocidade de uma reação é proporcional à concentração de uma substância.

Acredita-se que a função da catalase e das peroxidases, bem como da superóxido dismutase, é proteger os tecidos animal e vegetal contra os efeitos tóxicos da $\mathrm{H}_{2} \mathrm{O}_{2}$ formada durante o metabolismo celular. A remoção da $\mathrm{H}_{2} \mathrm{O}_{2}$, em nível celular, evita a formação do oxigênio singlete $\left({ }^{1} \mathrm{O}_{2}\right)$ pela reação com o $\mathrm{O}_{2} \because \mathrm{A}$ lactoperoxidase em leite tem ação antibacteriana.

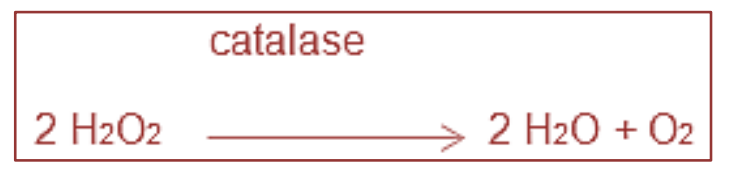

Essa enzima é importante dos pontos de vista nutricional, de coloração e flavor. Por exemplo, a atividade da peroxidase pode levar à destruição da vitamina $\mathrm{C}$ e descoloração de carotenoides e antocianinas, além de catalisar (grupo heme) a degradação não-enzimática de ácidos graxos insaturados, com a consequente formação de compostos voláteis (sabor oxidado).

A atividade da peroxidase está associada ao aparecimento de sabores estranhos em alimentos termicamente processados de maneira inadequada, sem que ocorra a inativação da enzima. Na presença de $\mathrm{H}_{2} \mathrm{O}_{2}$, ela é capaz de oxidar compostos fenólicos.

A peroxidase é considerada uma das enzimas mais termorresistentes, de forma que, quando inativada, certamente as demais enzimas e os microrganismos patogênicos serão destruídos. Na maioria dos casos, o branqueamento entre $90-100{ }^{\circ} \mathrm{C}$ por 3 minutos é o suficiente para destruí-la.

No processamento de frutas e vegetais, a peroxidase é a principal responsável pela formação de flavor estranho durante o armazenamento de produtos enlatados, principalmente em vegetais não-ácidos. Sua atividade diminui em pH baixo e pH elevado. A perda da atividade observada com acidificação é atribuída a mudanças do estado nativo para a condição desnaturada, ocasionada pela liberação do grupo heme da proteína. Portanto, a alteração da atividade com o pH está relacionada com a mudança estrutural na molécula da enzima. A regeneração da enzima após o tratamento térmico é dependente do $\mathrm{pH}$, e valores entre 5,0 e 8,0 recuperam sua atividade, enquanto em $\mathrm{pH}$ abaixo de 5,0 ocorre perda adicional. $0 \mathrm{pH}$ ótimo para atividade da peroxidase varia com a fonte, oscilando de 3,0 a 7,0.

0 inibidor químico mais frequentemente utilizado no controle da peroxidase na indústria é o dióxido de carbono ou sulfitos. A utilização de 0,1 a $0,15 \%$ de metabissulfito de sódio previne a formação de flavor estranho durante o armazenamento de vegetais processados. A ação do sulfito se verifica na destruição da $\mathrm{H}_{2} \mathrm{O}_{2}$, bloqueando a atividade da enzima, pela manutenção do substrato na sua forma reduzida.

Para o enlatamento e congelamento de vegetais, é importante que o procedimento de branqueamento seja adequado, evitando o desenvolvimento de sabores e odores estranhos no produto processado durante o seu armazenamento. Diversas enzimas como a catalase, peroxidase, polifenoloxidase e lipoxigenase, devem ser inativadas pelo branqueamento para se garantir produto congelado estável.

Método simples, mas não quantitativo, para verificar a adequação do branqueamento é a adição de uma gota de solução 0,5 a 3,0\% de peróxido de hidrogênio na superfície cortada do vegetal branqueado. 0 aparecimento da coloração rósea indica a presença da peroxidase, enquanto o aparecimento de bolhas indica presença de oxidase. A diminuição da atividade da peroxidase é considerada o melhor indicador de qualidade em vegetais congelados. Entretanto, a enzima desnaturada tende a regenerar sua atividade durante $\mathrm{o}$ armazenamento. 
Tabela: Atividade da peroxidase em vegetais

\begin{tabular}{|l|c|}
\hline \multicolumn{1}{|c|}{ Vegetal } & \multicolumn{1}{c|}{$\begin{array}{c}\text { Atividade da } \\
\text { peroxidase } \\
\text { (Unidades/kg) }\end{array}$} \\
\hline Repolho & 562 \\
\hline Vagem & 515 \\
\hline Abóbora & 361 \\
\hline Espinafre & 195 \\
\hline Aipo & 41 \\
\hline Batata & 40 \\
\hline Alho-porro & 37 \\
\hline Cenoura & 12 \\
\hline Cebola & 8 \\
\hline \multicolumn{2}{|c|}{ Fonte: Araújo, 2008 } \\
\hline
\end{tabular}

Exemplos de enzimas com alta eficiência: Acetilcolinesterase (transmissão do impulso nervoso), Anidrase carbônica (remoção de $\mathrm{CO}_{2}$ dos tecidos) Catalase e Superóxido dismutase (remoção de radicais livres do oxigênio). Um exemplo de enzima com pouca eficiência: Pepsina.

\section{COFATORES}

São denominados Cofatores moléculas ou íons que se associam a um grande número de enzimas para que elas possam exercer seu papel catalítico. Eles podem ser íons metálicos ou moléculas orgânicas, nãoproteicas, de complexidade variada, que recebem o nome de coenzimas. Os íons metálicos ligam-se aos radicais de aminoácidos de cadeia proteica ou estão presentes em grupos prostéticos. As enzimas atuam como aceptores de átomos ou grupos funcionais retirados do substrato em uma dada reação e como doadores destes mesmos grupos ao participarem de uma outra reação. Por isto diz-se que são transportadoras de determinados grupos. Durante a catálise, coenzima e substrato acham-se alojados no centro ativo da enzima, consistindo a reação na remoção de determinado grupo químico do substrato e sua transferência para a enzima, ou vice-versa. Em alguns casos, a coenzima encontra-se ligada covalentemente à molécula enzimática, constituindo, portanto, um grupo prostético da proteína; em outros casos, a coenzima é uma molécula "livre", reunindo-se à enzima apenas no momento da catálise. A estrutura química de uma coenzima é bastante variável. Algumas como a Adenosina Trifosfato (ATP) e a Guanina Trifosfato (GTP) são completamente sintetizadas pelas células. Outras apresentam um componente orgânico que não pode ser sintetizado pelos animais superiores. Deve ser obtido através da dieta, constituindo uma vitamina.

As vitaminas são necessárias na dieta em pequenas quantidades já que são precursores de coenzimas. As vitaminas são divididas em Hidrossolúveis e Lipossolúveis. As Hidrossolúveis incluem as vitaminas do complexo $B$ : tiamina $\left(B_{1}\right)$, riboflavina $\left(B_{2}\right)$, ácido pantotênico $\left(B_{3}\right)$, nicotinamida $\left(B_{5}\right)$, piridoxina $\left(B_{6}\right)$; biotina $\left(\mathrm{B}_{7}\right)$, ácido fólico $\left(\mathrm{B}_{9}\right)$, cobalamina $\left(\mathrm{B}_{12}\right)$ e o ácido ascórbico (vitamina $\left.\mathrm{C}\right)$. As vitaminas lipossolúveis são: A, D, E, K. São as vitaminas hidrossolúveis as que têm função de coenzimas ou fazem parte de moléculas de coenzimas. 


\section{CAPÍTULO \\ 06 Pigmentos e Corantes}

Um aspecto muito importante nos alimentos diz respeito a cor que apresentam. Dessa maneira, desde o início do processamento do alimento, na cozinha ou na indústria, existe o desejo de que as cores naturais dos alimentos sejam mantidas. Alguns alimentos adquirem cor através do processamento. Nos últimos anos, os consumidores têm mostrado crescente preocupação pelo uso de pigmentos sintetizados quimicamente como corantes em alimentos.

Um dos mais importantes atributos da qualidade sensorial de um alimento é a cor. Neste trabalho a palavra cor é utilizada para indicar a percepção pelo olho humano dos produtos coloridos. 0 termo corante é uma designação geral que se refere a qualquer composto químico que produza cor. Durante o processamento ou armazenamento de alimentos pode haver formação de substâncias coloridas. Ex: caramelos e melanoidinas.

Os pigmentos podem ter propriedades que vão além das dos corantes, por exemplo, eles podem funcionar como receptores de energia, transportadores de oxigênio ou protetores contra as radiações.

Os pigmentos naturais são divididos em cinco grupos principais:

1- Compostos heterocíclicos com estrutura tetrapirrólica:

Este grupo compreende as clorofilas encontradas em vegetais, como o heme e as bilinas encontradas em animais.

2- Compostos de estrutura isoprenoide, os carotenoides:

Encontrados em vegetais e animais, mas na sua maioria em vegetais.

3- Compostos heterocíclicos contendo oxigênio, os flavonoides:

Pigmentos encontrados somente em vegetais.

4- Compostos nitrogenados, encontrados apenas em vegetais, as betalaínas.

5- $\quad$ Os taninos que agrupam uma série de compostos extremamente variáveis.

\section{I - PIGMENTOS NATURAIS ENCONTRADOS EM ALIMENTOS}

\section{CLOROFILA}

A denominação clorofila foi usada originalmente para descrever aqueles pigmentos verdes relacionados com a fotossíntese das plantas superiores. Entretanto, se tem estendido a toda classe de pigmentos porfirínicos fotossintéticos. 0 pigmento verde das plantas foi descrito pela primeira vez em 1818 por Pelletier e Caventou, a quem se deve o nome de clorofila. Em 1868, Stokes demonstrou que esse pigmento verde era na verdade constituído por uma mistura de compostos que foram obtidos na forma relativamente pura pela primeira vez por Sorby, em 1873, ao empregar o método de partição entre metanol e dissulfeto de carbono. Há uma diversidade de clorofilas tais como a, b, c e d; as bacterioclorofilas a e b e as clorofilas de clorobium.

\section{LOCALIZAÇÃO NAS PLANTAS}

Nos alimentos é importante se estudar principalmente as clorofilas $\mathbf{a}$ e b, presentes nas plantas superiores na proporção aproximada de 1:3 (clorofila a / clorofila b). Ocorrem nos cloroplastos provavelmente associadas a proteínas, lipoproteínas e lipídeos. São obtidas por extração com solventes orgânicos sendo o 
mais indicado a acetona. Nos cloroplastos, juntamente com as clorofilas, é encontrada outra classe de pigmentos, os carotenoides. Estudos feitos em uma grande variedade de plantas mostraram que os pigmentos verdes dessas plantas eram sempre os mesmos, e que a diferença nas cores era devida à presença de carotenoides, que existem na concentração aproximada de 0,05\% (carotenos mais xantofilas), para $0,25 \%$ de clorofilas.

Dentro do cloroplasto, as clorofilas são visualizadas como imersas entre uma camada de proteína e lipídeo com um carotenóide situado ao largo da cadeia fitol da clorofila.

\section{ESTRUTURA QUÍMICA}

Willistater, em 1910, estabeleceu a estrutura básica das clorofilas: uma estrutura tetrapirrólica, denominada porfina, mas apenas em 1940 é que as estruturas completas destes pigmentos foram definitivamente estabelecidas por Hans e Fischer: Em microrganismos existem também as clorofilas $\mathbf{c}$ e $\mathbf{c}_{\mathbf{1}}$ cujas estruturas são semelhantes às descritas acima.

\section{TERMINOLOGIA}

Em qualquer estudo sobre clorofilas é essencial definir as estruturas e a terminologia química:

[1] Pirrol: é um dos quatro componentes cíclicos do núcleo de porfirina.

[2] Porfina: é o esqueleto tetrapirrólico completamente conjugado, formado por quatro anéis pirrólicos unidos.

[3] Porfirina: na Química da clorofila esse é o termo que compreende todos os tetrapirróis, próximos entre si completamente conjugados. 0 composto - mãe desta classe é a porfina, que pode ser substituída por vários grupos, como metila, etila ou vinila.

[4] Clorinas: são dihidroporfinas.

[5] Forbina: é uma porfirina com adições nos anéis C9 - C10.

[6] Fórbido: todas as porfirinas que ocorrem naturalmente têm um resto de ácido propiônico na posição 7. Nas clorofilas esta posição está esterificada com um álcool de cadeia longa (fitol ou farnesol). A estrutura correspondente, sem esterificar se conhece como fórbido se não contém magnésio.

[7] Fitol: é um álcool de 20 carbonos com estrutura isoprenóide.

[8] Feoforbídeo: é a feofitina menos o fitol.

[9] Feofitina: é a clorofila com o cátion magnésio substituído por prótons.

[10] Filina: é derivado de uma clorina contendo o cátion magnésio.

[11] Clorofilina: é a clorofila com os dois ésteres hidrolisados (o ácido dicarboxílico).

\section{PROPRIEDADES FÍSICAS}

A clorofila a e a feofitina a são solúveis nos álcoois, éteres, benzeno e acetona. Quando puras, são apenas ligeiramente solúveis em éter de petróleo. São insolúveis em água. A clorofila b e a feofitina b são solúveis em álcoois, éteres, acetona e benzeno. Quando puras são quase insolúveis em éter de petróleo e insolúveis em água. Os clorofílidos e feofórbidos em geral são insolúveis em compostos apolares e solúveis em água.

\section{PROPRIEDADES QUÍMICAS}

Quimicamente, as clorofilas podem ser alteradas de muitas formas, porém no processamento de alimentos a alteração mais comum é a feofitinização que é a substituição do átomo central de magnésio por hidrogênio por ação de ácidos diluídos e a conseqüente formação de feofitinas de cor verde-oliva, que prejudica a aparência de alimentos ricos em clorofilas. É difícil explicar a troca da cor simplesmente por substituição do magnésio por hidrogênio. Admite-se que ocorra certa mudança na estrutura de ressonância da feofitina. Outra alteração ocorre quando o fitol é removido por álcalis com formação de 
clorofilidas, compostos de cor verde que possuem praticamente a mesma absorbância das clorofilas, embora sejam mais solúveis em água.

Um fenômeno adicional muito importante que acontece com as clorofilas é a facilidade com que os íons de magnésio nesses pigmentos são substituídos por metais divalentes. Os complexos formados com cobre têm cor verde brilhante, o que faz com que os alimentos se tornem mais atraentes. Esses complexos têm o metal firmemente ligado, somente sendo libertado pela ação de ácidos concentrados, o que torna seguro o seu emprego em alimentos, uma vez que o cobre nessa forma não é absorvido pelo organismo. No entanto, por medida de segurança a quantidade de cobre livre ionizável não deve ultrapassar a $200 \mathrm{ppm}$. 0 seu uso em alimentos é permitido em vários países.

\section{EFEITOS DA MANIPULAÇÃO, PROCESSAMENTO E ARMAZENAMENTO DOS ALIMENTOS}

Quase todos os tipos de processamento de alimentos ou processamento combinado com armazenamento produzem alguma deterioração dos pigmentos clorofila. Já foi observado que produtos desidratados guardados em vidros claros se fotooxidam com perda da cor desejada. Nos alimentos desidratados se produz a conversão de clorofila em feofitina.

Muitas condições afetam o conteúdo de clorofila. As verduras podem mostrar trocas de cor ao serem congeladas e armazenadas. Ex: a degradação a compostos não clorofílicos das ervilhas e feijões se devem a ação da lipoxigenase. As lipoxigenases produzem radicais livres que degradam a clorofila. A irradiação - $\gamma \mathrm{e}$ o posterior armazenamento produz a degradação das clorofilas a feofitinas. A fermentação dos pepinos dá lugar a formação de feofitinas, clorofílidos e feofórbidos.

A cor das hortaliças verdes tratadas pelo calor muda de verde brilhante a um verde-oliva pardo devido à conversão da clorofila em feofitina pela influência dos ácidos produzidos durante o processamento térmico. Nos espinafres, ervilhas e feijões verdes existem ou se formam dez ácidos durante o processamento térmico sendo um dos principais ácidos que participam na degradação do pigmento o ácido acético.

\section{CONSERVAÇÃO DA COR VERDE}

Já foram realizadas muitas pesquisas e obtidas diversas patentes para a conservação da cor verde das hortaliças processadas termicamente. Infelizmente, nenhuma teve realmente êxito. Existem, entre outros, o "Processo Blair" que consiste no emprego de sais alcalinos, hidróxidos de cálcio e/ou magnésio, para fixar o íon magnésio na molécula de clorofila. Este processamento dá um produto atraente imediatamente após o tratamento, porém, não quando é conservado. Outras patentes baseadas no tratamento alcalino foram também pouco valiosas.

O processamento pelo método HTST tem a vantagem geral de destruir a população microbiana com menos destruição química que a que ocorre durante o processamento térmico convencional. Clydesdale, F.M. (2009) tentou combinar o tratamento alcalino, a conversão enzimática a clorofílido e o processamento HTST para manter a cor verde do espinafre. Porém, não teve êxito.

Atualmente a melhor maneira de manter a estabilidade da clorofila é trabalhar com produtos de alta qualidade, processá-los o mais rápido possível e armazená-los a baixas temperaturas.

\section{MIOGLOBINA E HEMOGLOBINA}

A química da cor da carne é a química dos pigmentos "heme". Mais especificamente, é fundamentalmente a química de um pigmento, a mioglobina. O grupo "heme" é o grupo prostético de duas cromoproteínas importantes: a proteína do sangue e a da carne, as duas com funções semelhantes, isto é, ambas complexionam com o oxigênio, o que é essencial para a atividade biológica animal.

A substância corante do sangue é a hemoglobina, uma proteína existente em quase todos vertebrados, muitos invertebrados e, excepcionalmente, em microrganismos. Foi a primeira proteína a ser obtida na forma cristalizada. Ela facilmente se combina com o oxigênio do ar, formando a oxi-hemoglobina. A ligação pigmento-proteína pode ser facilmente rompida produzindo heme, composto também com estrutura tetrapirrólica, a porfirina, semelhante à das clorofilas, ligada a um íon ferroso. 
Por oxidação, o heme dá origem à hematina, pigmento no qual o íon ferroso é oxidado a íon férrico; quando na forma de cloreto, este pigmento é denominado hemina: Como nas clorofilas, o heme perde facilmente o íon ferroso com formação de porfirina.

A mioglobina em suas diversas formas químicas, não é o único pigmento muscular, nem o mais importante biologicamente, é sim, em geral, o único pigmento presente em quantidades suficientemente grandes para colorir a carne.

Os pigmentos musculares importantes no músculo vivo e que não contribuem em nada ou quase nada na cor total do sangue são os citocromos (pigmentos heme vermelhos, que contêm ferro em uma estrutura complexa porfirina-proteína), a vitamina $\mathrm{B}_{12}$, uma estrutura muito mais complexa que a hemoglobina e que contém o mesmo anel porfirina que o heme e os citocromos e que possui um átomo de cobalto em vez de ferro, as flavinas coenzimas amarelas que participam com os citocromos no transporte de elétrons nas células, e a hemoglobina.

A mioglobina é uma proteína muscular complexa com função semelhante ao pigmento sanguíneo hemoglobina e ambas têm a propriedade de formar um complexo com o oxigênio necessário para a atividade metabólica do animal. A mioglobina é um parente da hemoglobina que tem 1/4 de seu tamanho e está formada por uma cadeia polipeptídica de uns 150 aminoácidos unidos a um só grupo heme. Está contida no interior das células dos tecidos e atua como armazém temporal do oxigênio transportado pela hemoglobina do sangue.

A hemoglobina dos glóbulos vermelhos contém quatro cadeias polipeptídicas e quatro grupos heme, os quais são agregações planares de átomos com um átomo de ferro no centro. A função do grupo heme é combinar-se reversivelmente com uma molécula de oxigênio a qual é transportada pelo sangue desde os pulmões aos tecidos.

\section{ESTRUTURA}

Tanto a hemoglobina como a mioglobina são proteínas complexas, o que quer dizer, que além da porção proteica da molécula, existe outra metade, de natureza não peptídica formando complexo com a cadeia peptídica. A metade proteica se conhece como globina e a porção não peptídica se denomina heme.

0 heme é composto de duas partes, um átomo de ferro e um grande anel planar, a porfirina. A porfirina está formada de quatro subunidades, o composto heterocíclico pirrol.

A hemoglobina, pode-se dizer que é formada por quatro mioglobinas unidas; portanto, o estudo da Química destes pigmentos se limita a mioglobina.

\section{PROPRIEDADES FÍSICAS}

A mioglobina forma parte das proteínas sarcoplasmáticas do músculo. É solúvel em água e nas soluções salinas diluídas.

\section{PROPRIEDADES QUÍMICAS}

Ao se considerar os pigmentos cárnicos, com relação à qualidade, é necessário tratar os principais complexos de heme, globina e os ligantes que rodeiam o ferro no estado oxidado $\left(\mathrm{Fe}^{3+}\right)$ ou reduzido $\left(\mathrm{Fe}^{2+}\right)$. A reação que define o complexo covalente formado entre a mioglobina e o oxigênio molecular para dar a oxihemoglobina se conhece como oxigenação e é diferente da oxidação da mioglobina para formar metamioglobina.

Além disso, tais complexos se podem agrupar como de tipo iônico e covalente, nos que as ligações do tipo covalente produzem os pigmentos de cor vermelho brilhante desejados para a carne. A oxihemoglobina, nitrosomioglobina e carboximioglobina são exemplos de complexos covalentes ferrosos da mioglobina com oxigênio molecular, óxido nítrico e monóxido de carbono, respectivamente.

A cianometamioglobina e o hidróxido de metamioglobina são exemplos de complexos covalentes do íon férrico que têm a característica cor vermelha. 0 ciclo de cor das carnes frescas é reversível e dinâmico, com os três pigmentos, oximioglobina, mioglobina e metamioglobina, interconvertendo-se constantemente. 
A metamioglobina parda, a forma oxidada ou férrica do pigmento, não pode ligar oxigênio pois é oxidada pelo mesmo oxigênio que converte a mioglobina em oximioglobina vermelha (oxigenação). Portanto, na presença de oxigênio, a mioglobina púrpura pode ser oxigenada ao pigmento oxihemoglobina vermelha brilhante produzindo a familiar cor das carnes frescas, ou pode ser oxigenada a metamioglobina, produzindo a cor parda não desejada das carnes menos aceitáveis.

\section{EFEITOS DA MANIPULAÇÃO, PROCESSAMENTO E ARMAZENAMENTO PIGMENTOS DAS CARNES CURADAS}

Se o sistema no qual se formam os pigmentos da carne curada têm nitrito, os pigmentos heme se encontram no estado inicial oxidado, posto que o nitrito é um forte oxidante do pigmento heme. Em geral, a formação do pigmento ou cromóforo da carne curada se considera que ocorre em duas fases:

- Reações bioquímicas, que reduzem o nitrito a óxido nítrico e reduzem o ferro do heme ao estado ferroso.

- Desnaturação térmica da globina. Ocorre apenas quando a carne curada é aquecida a $66^{\circ} \mathrm{C}$ ou mais e é acompanhada da co-precipitação do pigmento heme com outras proteínas da carne. Mesmo que não esteja claro para carne ou produtos cárnicos, os mecanismos que intervêm na reação completa, estabelecem que o produto final é nitrosilmioglobina se a carne não é aquecida e nitrosilhemocromógeno globina desnaturada se a carne é aquecida.

Na cor da carne curada outros fatores são também importantes. Pesquisadores trabalhando com salsichas de Frankfurt observaram que o período de espera na produção de cor, atribuído a presença de oxigênio, se reduziu picando à carne sob nitrogênio, usando vácuo ou por adição de ascorbato ou cisteína.

\section{EMPACOTAMENTO}

Nas carnes frescas é usado devido às reações que o pigmento sofre com o oxigênio para produzir um produto aceitável. A carne é empacotada para:

- Proteger o produto da contaminação com bactérias ou pó.

- Retardar ou prevenir a perda de umidade do produto.

- Proteger o produto do oxigênio ou da luz.

- Facilitar o manejo.

- Ajudar a mantê-la atraente.

A acelerada velocidade de oxidação do pigmento heme a baixas pressões parciais de oxigênio é de grande importância quando se consideram as películas empregadas para empacotar as carnes frescas. Tem-se usado monóxido de carbono misturado ao ar para tratar os pacotes de carne antes de fechá-los. Este tratamento tem se mostrado muito eficaz para conservar e estabilizar a cor da carne fresca durante uns quinze dias. Deve-se levar em conta, porém, a toxicidade do monóxido de carbono.

A luz utilizada nas gôndolas onde se expõem os alimentos é um fator importante que influi sobre a cor da carne. Outros fatores, como a presença de íons metálicos, também afeta a oxidação de $\mathrm{O}_{2} \mathrm{Mb}$, e, portanto, a cor da carne fresca. $\mathrm{O}$ cobre é extremamente ativo como promotor da autoxidação de $\mathrm{O}_{2} \mathrm{Mb}$ a $\mathrm{MMb}$; outros metais como $\mathrm{Fe}, \mathrm{Zn}$ e $\mathrm{Al}$ são menos ativos.

\section{B I L I N A S}

Entre os produtos do metabolismo de algumas porfirinas encontra-se uma série de compostos nãometálicos, também tetrapirrólicos, mas de estrutura acíclica, e contendo grupos carboxílicos na molécula. São as bilinas, pigmentos encontrados na bílis, entre os quais o mais importante é a bilirrubina. 


\section{CAROTENOIDES}

Os carotenoides são um grupo de compostos principalmente lipossolúveis, responsáveis por muitas das cores amarela e vermelha dos produtos vegetais e animais. Estão amplamente distribuídos e existem na natureza em grandes quantidades. Segundo estimativas são produzidas anualmente na natureza mais de 100.000.000 de toneladas de carotenoides. A maior parte se encontra na forma de fucoxantina em diversas algas e nos três principais carotenoides das folhas verdes (luteína, violaxantina e neoxantina) outros carotenoides produzidos em quantidades muito menores, porém largamente distribuídos, são o $\beta$ caroteno e a zeaxantina. Outros pigmentos predominam em certas plantas como o licopeno nos tomates, a capsantina nas pimentas vermelhas e a bixina no urucum.

\section{ESTRUTURA}

Os carotenoides constituem uma classe de hidrocarbonetos denominados carotenos e seus derivados oxigenados, as xantofilas. São formados por oito unidades isoprenoides ligadas de modo tal que a disposição destas unidades se inverte no centro da molécula. A estrutura básica do licopeno mostra a distribuição assimétrica ao redor do par de carbono central. Esta estrutura pode ciclizar para formar $\beta$ caroteno. Outros carotenoides têm diferentes grupos terminais com a mesma estrutura central. Conhecese uns sessenta grupos terminais diferentes, compreendendo os quatrocentos e cinquenta carotenoides conhecidos e continuamente estão sendo descobertos outros novos. A maior parte dos carotenoides, estudados antigamente, têm um esqueleto central com quarenta carbonos, porém recentemente tem sido descrito alguns que contem mais de quarenta carbonos.

Os carotenoides podem apresentar-se na forma livre nos tecidos vegetais (como cristais ou sólidos amorfos) ou em dissolução em lipídeos. Também se apresentam como ésteres ou em combinação com açúcares e proteínas. A existência de carotenoides na forma de ésteres de ácidos graxos se conhece há muito tempo. Por exemplo, nas folhas outonais, os ácidos palmítico e linoleico se associam com as posições 3 e 3' da luteína. No pimentão a capsantina se acha na forma de éster do ácido láurico. Tem sido descrito ésteres dos carotenoides em flores, frutas e bactérias.

A associação de carotenoides com proteínas tem sido estudada mais recentemente, e seu conhecimento se tem desenvolvido principalmente a partir do estudo de pigmentos de diversos invertebrados. A associação de carotenoides com proteínas estabiliza o pigmento, porém muda a cor. Por exemplo, o carotenoide astaxantina de cor vermelha quando forma um complexo com proteína, como acontece na carapaça da lagosta. Outro exemplo é a ovoverdina, o pigmento verde dos ovos de lagosta. Os complexos carotenoideproteína, também existem em algumas folhas, bactérias, frutas e hortaliças.

Os carotenoides também podem apresentar-se em combinação com açúcares redutores através de ligações glicosídicas. Durante muitos anos a crocina, que contem duas moléculas do açúcar gentibiose unidos à crocetina, foi o único conhecido deste tipo. A crocina é o principal pigmento do açafrão. Recentemente tem sido isolado certo número de carotenoides glicosídicos das bactérias.

\section{REAÇõES QUÍMICAS}

Pró-vitamina A. Os carotenoides têm recebido grande atenção por parte dos pesquisadores, porque o $\beta$ caroteno é um precursor da vitamina A, um nutriente bem conhecido da dieta humana. Por cisão no centro da molécula, o $\beta$ - caroteno dá duas moléculas de vitamina A. Compostos como o $\alpha$ - caroteno com a metade de sua estrutura idêntica $\beta$ - caroteno, funciona como precursor de uma molécula de vitamina $A$.

Reações de oxidação. A causa principal da degradação dos carotenoides dos alimentos é a oxidação. A intensidade da oxidação depende do pigmento se encontrar in vivo ou in vitro, e das condições ambientais. Nos tecidos vivos intactos, a estabilidade dos pigmentos provavelmente é função da permeabilidade celular e da presença de componentes protetores. Por exemplo, o licopeno dos tomates é muito estável, porém o pigmento extraído e purificado é instável. Presentes em muitos tecidos existem sistemas enzimáticos que degradam rapidamente os carotenoides. Por exemplo, nos macerados de folhas verdes a metade dos carotenoides desaparece em vinte minutos à temperatura ambiente. As lipoxigenases degradam os carotenoides em alguns alimentos.

Nos alimentos processados o mecanismo de oxidação é complexo e depende de muitos fatores. Os pigmentos podem autoxidar-se por reação com oxigênio atmosférico a velocidades que dependem da luz, do calor e da presença de pro - e antioxidantes. Acredita-se que as reações são devidas a formação de 
radicais livres em três etapas distintas. Os carotenoides sofrem oxidação acoplada em presença de lipídios à velocidades que dependem do sistema. Os carotenoides normalmente são mais estáveis em sistema com alto grau de insaturação, possivelmente porque o sistema lipídico por si mesmo aceita os radicais livres mais facilmente que o caroteno. Ao contrário, os carotenos são menos estáveis em sistemas lipídicos com baixo grau de insaturação; na bibliografia existem muitas exceções a este respeito. Os carotenoides podem atuar como antioxidantes ou pro-oxidantes dependendo do sistema.

Em vista das variações da estrutura dos carotenoides e das complicadas interações com o meio que o rodeia, é provável que nos alimentos ocorra certo número de mecanismo de oxidação.

\section{OCORRÊNCIA DE CAROTENOIDES EM ALIMENTOS NO BRASIL}

As frutas tropicais, na sua maioria devem a sua cor a estes pigmentos. Em laboratório, já foi determinada a composição de carotenoides, de caju, maracujá, abricó, tomate, tucumã, goiaba, mamão e outros.

$0 \beta$ - caroteno é o pigmento principal do caju, seguido por criptoxantina. 0 teor de carotenoide total do caju vermelho é o dobro do caju amarelo. Os dois tipos de caju possuem a mesma composição qualitativa.

Em maracujá, a predominância é do $\delta$ - caroteno $(13,2 \mu \mathrm{g} / \mathrm{g})$ seguido do $\beta$ - caroteno $(6,2 \mu \mathrm{g} / \mathrm{g})$. Os outros carotenoides identificados nesta fruta são $\alpha$ - caroteno, neurosporeno, $\gamma$ - caroteno e licopeno.

O licopeno é o principal pigmento da goiaba cultivar IAC-4, a variedade cultivada na maioria dos pomares do estado de São Paulo. O licopeno corresponde a $86 \%$ de $62 \mu \mathrm{g} / \mathrm{g}$ de carotenoide total. Outros pigmentos presentes são $\beta$ - caroteno, $\delta$ - caroteno, $\gamma$ - caroteno, zeinoxantina e etc. Os mesmos carotenoides aparecem em goiabas de Fortaleza e Recife. Embora o teor de licopeno nas goiabas do Nordeste seja próximo ou menor ao encontrado na goiaba IAC-4 o teor de $\beta$ - caroteno é maior.

Na fruta do pé de tomate, uma fruta nativa do Brasil, os carotenoides são $\beta$ - caroteno, criptoxantina, luteína, zeaxantina e outros. Aparecem tanto na casca como na polpa.

Embora o principal pigmento seja obviamente a clorofila, várias hortaliças (salsinha, coentro, couve, rúcula, agrião, almeirão, chicória), possuem alto teor de $\beta$ - caroteno. Isso significa que essas folhas são fontes altamente ricas de provitamina A.

Os dois alimentos mais estudados em relação aos carotenoides são tomates e cenouras. Valores de 20 $60 \mu \mathrm{g} / \mathrm{g}$ (base seca) de carotenoide total foram relatados para o tomate, cujo principal pigmento é o licopeno. Para a cenoura valores de $54-122 \mu \mathrm{g} / \mathrm{g}$ de carotenoides foram obtidos. Os pigmentos predominantes são $\alpha$ - e $\beta$ - caroteno.

Na manga 50 - 60\% do carotenoide total é constituído por $\beta$ - caroteno.

Os principais carotenoides da polpa de banana que contém apenas 6 - 10 $\mu \mathrm{g} / \mathrm{g}$ de carotenoide total são $\alpha$ caroteno (31\%), $\beta$ - caroteno (28\%) e luteína (33\%).

0 carotenoide total do melão $(20,2 \mu \mathrm{g} / \mathrm{g}) 84,7 \%$ é representado por $\beta$ - caroteno.

No caqui há predomínio também de criptoxantina, perfazendo $40 \%$ do carotenoide total.

Vinte e um carotenoides foram detectados na melancia. De 24,6 $\mu \mathrm{g} / \mathrm{g}$ de carotenoides, 73,3\% é preenchido por licopeno.

Na polpa de abacate, há predominância de luteína que representa 25\% do carotenoide total (10 - $14 \mu \mathrm{g} / \mathrm{g})$.

\section{ANTOCIANINAS}

Correspondem a um grupo de pigmentos de cor vermelha, hidrossolúveis, amplamente distribuídos no reino vegetal. Muitas frutas, hortaliças e flores devem sua coloração atraente a este grupo de substâncias que existem no suco celular. Sua chamativa cor vermelha atraiu o interesse sobre sua estrutura química, desde o clássico trabalho de Paul Karrer (1889-1971).

A estrutura do grupo das antocianinas é bem conhecida, mas a físico-química dos complexos do pigmento e suas reações de degradação são menos conhecidas. 


\section{ESTRUTURA}

Todas as antocianinas derivam-se da estrutura básica do cátion flavílio. São conhecidas vinte antocianidinas, porém só seis, são importantes nos alimentos: pelargonidina; cianidina; delfinidinas; peonidina; petunidina e malvidina. As outras são relativamente raras e estão presentes em algumas folhas e flores.

Os pigmentos de antocianina compõem-se de aglicona (antocianidina) esterificada com um ou mais açúcares. As agliconas livres raramente existem nos alimentos, exceto possivelmente como componentes traços das reações de degradação. Somente se tem falado em cinco açúcares como parte das moléculas de antocianinas. São em ordem de abundância relativa: glicose, ramnose, galactose, xilose e arabinose. As antocianinas também podem ser aciladas, juntando-se portanto um terceiro componente à molécula.

Esterificadas com a molécula de açúcar se encontram uma ou mais moléculas de ácido p-cumárico, ferúlico, caféico, malônico, vanílico ou acético.

As antocianinas se podem dividir em grupos que dependem do número de moléculas de açúcar. Os monosídeos têm só um resíduo de açúcar, quase sempre na posição 3. Os biosídeos contêm 2 açúcares, ambos na posição 3 , ou 1 na posição 3 e outro na posição 5 , ou mais raramente nas posições 3 e 7. Os triosídeos contêm 3 açúcares, ordinariamente 2 na posição 3 e 1 na posição 5 . Não há descrição de antocianinas com 4 moléculas de açúcar, porém há evidência de sua existência. Também há evidência de 1 antocianina com 5 moléculas de açúcar e 4 componentes acila.

\section{ESTABILIDADE NOS ALIMENTOS}

O núcleo flavílio dos pigmentos de antocianina é deficiente em elétrons e, portanto, muito reativo. As reações normalmente compreendem a descoloração dos pigmentos e são quase sempre não desejáveis no processamento de frutas e hortaliças. A velocidade da destruição das antocianinas depende do $\mathrm{pH}$ e é rápida, a valores de $\mathrm{pH}$ elevados. A velocidade de reação depende também da quantidade de pigmento existente na forma de base carbinol incolor e é dependente da temperatura. Meschter, em suas pesquisas, calculou que a vida média do pigmento dos morangos em conserva é de 1300 hs a $20^{\circ} \mathrm{C}$ e de 240 hs a 38으. A reatividade da molécula de antocianina com o ar e com muitos dos componentes normalmente presentes nas frutas e hortaliças tem dado lugar a muitos estudos sobre a estabilidade das antocianinas.

\section{EFEITO DO pH}

A cor das antocianinas se modifica com as mudanças de $\mathrm{pH}$.

\section{$\mathrm{A} \leftrightarrow \mathrm{AH}+\leftrightarrow \mathrm{B} \leftrightarrow \mathrm{C}$}

Recentemente se descreveu um novo tipo de antocianinas que mostram uma resposta diferente ao $\mathrm{pH}$. Estes compostos têm substituições de açúcar no anel B da ordem de 2 ou mais grupos acila. Um composto deste tipo tem uma extraordinária estabilidade porque não se produz a forma pseudo-base carbinol devido ao impedimento estérico dos grupos acila.

\section{REAÇõES QUÍMICAS}

O sulfitado das frutas é um processo comercial importante para a conservação em bruto. A adição de sulfito ou de óxido de enxofre, tem como resultado o branqueamento rápido das antocianinas, que por sua vez termina dando cores amareladas atribuíveis a outros pigmentos. 0 processo consiste em reações de adição simples nas posições 2 ou 4, formando-se compostos que são incolores porém muito estáveis. A eliminação de sulfito por ebulição ou acidificação durante a fabricação de marmeladas se acompanha da regeneração das antocianinas.

Na reação das antocianinas com ácido ascórbico se produz uma interação de que resulta a degradação de ambos os compostos. A reação de peróxidos com antocianina é conhecida desde muito tempo e forma a base de um método para identificar o açúcar na posição 3 do composto flavílio. A oxidação peroxídica dos 
sais de flavílio dependendo das condições produz uma série de compostos diferentes. A oxidação do ácido ascórbico é catalisada pelo cobre e compostos de ferro, com a consequente maior velocidade da destruição das antocianinas. Inclusive a valores de $\mathrm{pH}$ baixo $(\mathrm{pH}=2)$ no qual as antocianinas são mais estáveis, é considerável a destruição causada pela interação com o ácido ascórbico. A presença de íons metálicos pode exercer um efeito protetor ligeiro a valores de $\mathrm{pH}$ baixo, porém este efeito é insignificante comparado com a grandeza da degradação causada pelo ácido ascórbico.

A acelerada descoloração das antocianinas na presença de ácido ascórbico, aminoácidos, fenóis, derivados de açúcares, etc., pode ser causada por reações de condensação com estes compostos. Os polímeros e os compostos de degradação produzidos por estas reações provavelmente são muito complexos. Alguns destes produtos de reação formam os compostos denominados flobafenos, que são de cor vermelha escura. Ex: a marmelada de morangos depois de dois anos de conservação à temperatura ambiente não mostra antocianinas detectáveis, porém, tem uma cor vermelha escura. Acredita-se que compostos deste tipo contribuem para a cor dos vinhos envelhecidos. Alguns pesquisadores têm assinalado a existência de sistemas enzimáticos que descolorem as antocianinas. Podem ser glicosídeos, que hidrolisam a ligação protetora 3 - glicosídica para dar agliconas instáveis ou fenolases, que requerem a interação de orto dihidroxifenóis.

\section{COMPLEXOS DE ANTOCIANINA}

A observação de que os pigmentos de antocianina vermelhos podem isolar-se de flores azuis tem estimulado uma considerável investigação sobre as possíveis estruturas que produzem a cor azul. Estas cores têm confirmado a copigmentação de antocianinas com flavonoides amarelos e outros polifenóis e à formação de complexos com outros componentes. Alguns destes complexos têm sido isolados e se tem observado que contêm cátions, tais como $\mathrm{Al}, \mathrm{K}, \mathrm{Fe}, \mathrm{Cu}, \mathrm{Ca}$ e $\mathrm{Sn}$; aminoácidos, proteínas, pectinas, carboidratos ou polifenóis. Todos estes complexos estão presentes nas flores.

Algumas antocianinas possuem hidroxilas vicinais as quais permitem formar complexos com metais. Por exemplo, quando as cerejas ácidas vermelhas, frutas que contêm antocianinas, são colocadas em latas estanhadas, se forma um complexo antocianina-estanho, responsável pela troca de cor de vermelho à púrpura.

\section{DERIVADOS DE ANTOCIANIDINA}

As restrições ao emprego de corantes alimentícios artificiais vermelhos têm despertado o interesse na utilização, como corantes dos alimentos, de compostos do tipo antocianina.

Pesquisadores têm descrito uma série completa de compostos que diferem nos substituintes na posição 3, que têm sido patenteados, porém infelizmente sofrem reações com o dióxido de enxofre, ácido ascórbico, pH e outros agentes.

Timberlake e Bridle informaram que as antocianidinas com um grupo metila ou fenila na posição 4 são muito estáveis na presença destes compostos, inclusive mais que os corantes artificiais vermelhos permitidos. Entretanto esta classe de compostos flavílio em posição 4 terá que ser considerada como compostos novos e, portanto, submetida às correspondentes provas de toxicidade.

\section{F L A V O N O I D E S}

\subsection{ESTRUTURA}

Os flavonoides amarelos compreendem uma classe de pigmentos, que têm uma estrutura química similar à das antocianinas. São conhecidos mais de oitocentos flavonoides, e seu número aumenta rapidamente. Um dos grupos principais é o dos flavonóis como o canferol, quercetina e miricetina. Outro grupo, menos comum que os flavonóis, é o das flavonas a que pertencem membros como a apigenina, luteolina e tricetina. Note-se a semelhança de estrutura com a pelargonidina, cianidina e delfinidina. São conhecidas outras sessenta agliconas baseadas em derivados hidroxi e metoxi das estruturas flavonol e flavona. Outros cinco grupos de menor importância são: as chalconas, auronas, flavanonas, isoflavanonas e os biflavonilos.

Estas agliconas ordinariamente existem em forma de glicosídeo com glucose, ramnose, galactose, arabinose, xilose, apiose ou ácido glucurônico. As posições de substituição são variadas, sendo as mais 
comuns as posições 7, 5, 4', 7, 4' e 3'. Em contraste com as antocianinas a posição 7 é ponto de substituições mais frequentes porque usualmente é o mais ácido dos grupos hidroxila. Os flavonoides também podem apresentar-se com substituintes acila de maneira semelhante às antocianinas. Também se tem isolado compostos nos quais a glicose está unida mediante ligações C-C na posição 6 ou na posição 8. Tais compostos são completamente resistentes à hidrólise ácida, e ainda que não sejam glicosídeos estritos, têm propriedades muito semelhantes. Os dois membros mais comuns são a vitexina e isovitexina.

\subsection{IMPORTÂNCIA NOS ALIMENTOS}

Os glicosídeos de quercetina e canferol são os flavonóis que estão quase universalmente distribuídos no reino vegetal e se apresentam em mais de 50\% das plantas investigadas. Tem-se observado glicosídeos da miricetina em mais de $10 \%$ das plantas estudadas. Muitas plantas contêm pigmentos flavonoides, sobre os quais se têm publicado muitos trabalhos.

As três agliconas flavonóis: quercetina, canferol e miricetina existem em quantidade considerável no chá em pó (instantâneo) responsável pela sua adstringência. No chá verde estes três compostos e seus glicosídeos podem alcançar até $30 \%$ do peso seco. Um flavonoide, a rutina (quercetina-3ramnoglucosídeo) forma um complexo com o ferro produzindo uma descoloração escura dos aspargos enlatados; ao contrário, o complexo com estanho produz uma cor amarela desejável. As flavanonas, um grupo menor de flavonoides, se encontram principalmente nas plantas cítricas; são de interesse devido ao seu potencial como edulcorantes sintéticos.

As isoflavonas têm débil atividade estrogênica. Por seu possível valor como antioxidante de gorduras e azeites tem despertado interesse o caráter polifenólico dos flavonoides e sua capacidade para sequestrar metais. Os flavonoides são relativamente estáveis ao tratamento térmico dos alimentos aquosos enlatados.

\section{PROANTOCIANIDINAS}

São incolores, porém têm semelhança estrutural com as antocianidinas e durante o processamento e manipulação dos alimentos podem converter-se em produtos coloridos. São também chamadas antoxantinas, antocianógenos, flavolanos, flavilanos e flavilógenos, porém o nome mais utilizado é o de proantocianidinas.

Os elementos constitutivos básicos das protoantocianidinas é ordinariamente o flavan-3,4-diol que forma um dímero mediante ligações $4 \rightarrow 8$ ou $4 \rightarrow 6$, porém também são frequentes trímeros e polímeros mais elevados. Todos produzem, quando aquecidos em presença de um ácido mineral, antocianidinas como pelargonidina, cianidina, petudinina ou delfinidina.

As proantocianidinas são importantes nos alimentos porque contribuem para seu sabor adstringente. São importantes "flavors" de muitas frutas e bebidas como maçãs, pêras, nêsperas, olivas, bananas, chocolate, chá e vinho. Também participam nas reações de escurecimento enzimático de frutas e hortaliças mediante seus grupos orto-hidroxila e na formação de turbidez na cerveja e no vinho. Para ser adstringentes têm que ter capacidade para reagir com as proteínas, e isto limita o tamanho do polímero de proantocianidina.

\section{TANINOS}

Também chamado ácido tânico, ácido galotânico. Seu aspecto vai desde incolor até amarelo ou pardo. 0 ácido tânico que se compra nas drogarias tem a fórmula $\mathrm{C}_{75} \mathrm{H}_{52} \mathrm{O}_{46},(\mathrm{PM}=1701)$ provavelmente é formado de nove moléculas de ácido gálico e uma de glicose.

O termo tanino, tal como se usa em alimentos, compreende dois tipos de compostos. 0 primeiro são os "taninos condensados" que podem ser dímeros 4,8 ou 2,8 C-C, ou dímeros de catequina com ligação éter 3,3 e compostos relacionados. Também se tem descrito outros compostos com ligações 2-C, 7-0 ou 4-C, 70 . O segundo tipo são os "taninos hidrolisáveis" tais como os galotaninos e os elagitaninos. Estes compostos caracterizam-se por sua capacidade de curtir peles na fabricação do couro. São polímeros do ácido gálico e do ácido elágico.

Os taninos contribuem para a adstringência dos alimentos e também para as reações de escurecimento enzimático, porém seu mecanismo de ação não é bem compreendido ainda. 


\section{BETALAÍNAS}

Compreendem um grupo de compostos semelhantes às antocianinas e flavonoides em seu aspecto visual. Denominavam-se "antocianinas que contêm nitrogênio". Estão presentes nos compostos hidrossolúveis do suco celular da acelga, figos, em certo número de flores como a buganvílias e o amaranto. São conhecidas cerca de setenta betalaínas e todas têm a mesma estrutura básica em que R e R' podem ser $\mathrm{H}$ ou um substituinte aromático. Sua cor é atribuída às estruturas de ressonância. Se R ou R' não aumentam a ressonância, o composto é amarelo e se denomina betaxantina. Se R e R' aumentam a ressonância, o composto é vermelho e se denomina betaciclina.

As antocianinas e as betalaínas têm estruturas químicas diferentes e se distinguem facilmente. As antocianinas são extraídas facilmente com metanol e são muito pouco solúveis em água. 0 contrário é válido para as betalaínas.

As betalaínas degradam-se durante o processamento térmico, por exemplo: enlatamento, porém existe pigmento suficiente, de modo que o alimento mantém uma atraente cor vermelha escura. Ex: Beterraba. 0 pigmento isolado da beterraba é estável no intervalo de $\mathrm{pH}$ de 4-6, daí seu interesse como corante para alimentos.

Até 1892 se usava uma planta da família Phytolacca como adulterante de vinhos. A adição do suco da erva carmim ao vinho era uma solução para o caso de uvas pobres em pigmentos. Este corante se denominava antigamente fitolacanina, e sua estrutura é idêntica à da betanina.

\section{QUINONAS E XANTONAS}

As quinonas pertencem a um grande grupo de pigmentos amarelos existentes no suco celular das plantas com flores, fungos, líquens, bactérias e algas. São conhecidas mais de duzentas, cuja cor varia do amarelo pálido ao quase negro. 0 grupo maior é o das antraquinonas, do qual alguns membros têm sido utilizados durante séculos como corantes naturais e purgantes. Uma antraquinona típica é a emodina que se encontra amplamente distribuída em fungos, líquens e plantas superiores. As naftoquinonas são um pequeno subgrupo composto de uns vinte pigmentos. Diversos membros deste grupo são usados como corantes. A juglona que existe nas nozes e a plumbagina são naftoquinonas típicas. As antraquinonas ordinariamente se apresentam em forma de glicosídeos, porém as naftoquinonas não. Outro grande grupo são as benzoquinonas, que ocorrem ordinariamente em fungos e em algumas plantas com flores, um exemplo é o composto espinulosina de cor negro violáceo. Outro subgrupo de pigmentos vermelhos são as naftacenoquinonas, limitado somente aos Actinomicetais, está estreitamente relacionado com os antibióticos tetraciclina. Existem outros muitos subgrupos tais como as fenantraquinonas, as isoprenoidequinonas e um número de estruturas mais complexas.

As xantonas são um grupo de uns vinte pigmentos amarelos que se tem confundido com as quinonas e flavonas. Um membro bem conhecido desse grupo é a mangiferina, que existe em forma de glucosídeo nas mangas. As xantonas podem distinguir-se facilmente das flavonas e quinonas por suas características espectrais.

\section{OUTROS PIGMENTOS NATURAIS}

Existe certo número de grupos de compostos cujas estruturas diferem do usual conceito de cor carotenoide-flavonoide-quinonoide-porfirina. 0 surgimento de uma molécula colorida pode ser incidental, resultante de uma variação relativamente pouco importante que desloca a absorção da luz à área do visível. Como exemplo, tem-se as cetonas aromáticas, nas quais os compostos sensíveis são incolores, e os derivados complexos tais como o gosipol, são amarelos. 0 gosipol, uma substância tóxica se tem estudado a fundo devido a sua presença na farinha de algodão, pois esta farinha é uma fonte potencial de proteína para o homem. A pesquisa atual tem se concentrado em esforços genéticos para reduzir o conteúdo de gosipol e no processamento para eliminá-lo. 0 gosipol também tem sido notícia por outras razões. $\mathrm{Na}$ China estão sendo realizadas pesquisas para provar sua eficácia como anticonceptivo para o homem.

Muitas dienonas aromáticas estão presentes nos fungos. Um grupo de dienonas cíclicas se assemelha aos flavonoides e outro (dracorubina) é o pigmento "do sangue de dragão", uma resina exudada por algumas palmeiras. 
Existe também um pigmento fitocromo de cor amarela pálida que é muito importante para o crescimento global das plantas. Controla a elongação, floração, germinação, indução da latência e a produção de antocianinas e carotenoides.

\section{CORANTES ADICIONADOS AOS ALIMENTOS}

\section{ASPECTOS LEGAIS}

A legislação atual relativa à regulação e uso de corantes adicionados aos alimentos nos Estados Unidos é a "Food, Drug and Cosmetic Act" de 1938, ampliada pela "Color Additive Amendment" de 1960. Historicamente, a legislação tem centrado seu interesse nos corantes sintéticos já que têm sido muito mais controversos que os pigmentos naturais.

A síntese em 1856 da púrpura de anilina realizada por Sir William Perkin introduziu a era dos corantes sintéticos que eram muito superiores aos corantes naturais utilizados naquela época. No ano de 1900, existia no mercado cerca de 695 corantes diferentes, derivados do alcatrão e muitos deles se utilizavam em alimentos. Bernard Hesse da USDA estudou o problema dos corantes sintéticos nos alimentos e recomendou sete, que foram legalizados sob a "Pure Food and Drugs Act" de 1906 e nos anos seguintes se juntaram mais dez. Depois de muitas trocas e altas e baixas nas listas, são permitidos atualmente nos EUA poucos corantes sintéticos.

O número e tipo de corantes permitidos variam amplamente de um país a outro, porém existe uma tendência a utilizar pouco corantes sintéticos. É de esperar que ganhe terreno o desejo de uma padronização internacional dos corantes dos alimentos. De fato existe pouca justificação científica para utilização de uma grande variedade de corantes sintéticos posto que as misturas dos corantes aprovados permitem aos fabricantes obter quase qualquer cor desejada.

Do ponto de vista legislativo os corantes permitidos para adição aos alimentos se dividem em duas classes, certificados e sem certificação. Com a promulgação da "Federal Food, Drug and Cosmetic Act", de 1938 os fabricantes de corantes que necessitam de certificação (todos são sintéticos) têm enviado uma amostra de cada corante ao FDA para a sua certificação com o fim de assegurar que os preparados sejam inócuos e adequados para os alimentos. A lei de 1938 se refere a "Corantes Derivados do Alcatrão" que cria no consumidor a ideia de um produto desagradável e negro. Estes corantes naturalmente foram fabricados a partir de derivados do alcatrão faz setenta anos, porém atualmente a indústria petroquímica proporciona as matérias primas para a síntese de corantes. 0 termo alcatrão é obsoleto há mais de meio século e deveria ser abandonado.

A lei de 1938 permitia a utilização de corantes em qualquer quantidade. A FDA também interpretava o vocábulo inócuo no sentido de incapaz de produzir dano em qualquer espécie, em qualquer quantidade e sob quaisquer condições. Os dados toxicológicos segundo esta interpretação levaram a retirar da lista oito corantes FD\&C entre 1956 e 1960. É óbvio que segundo este acordo todos os corantes deveriam estar fora da lista. Isto levou à "Color Additives Amendment" de 1960, pela qual o FDA foi autorizado a estabelecer tolerâncias para a quantidade de corante permitido nos alimentos.

A lei de 1938, também continha regras para guiar os ensaios toxicológicos, a certificação, a pureza, a interpretação da inoquidade, etc. Além disso, a lei permitia o uso continuado de alguns corantes enquanto se obtinham dados toxicológicos adicionais. 0 suposto era que estes compostos teriam que ser listados permanentemente ou abandonados. Infelizmente a lista provisória para alguns compostos se prolongou durante muitos anos, porém esta situação está sendo retificada.

Entre os corantes que não necessitam de certificação permitidos para seu emprego nos alimentos se encontram os corantes naturais, assim como alguns corantes sintéticos (por exemplo, o $\beta$ - caroteno, seja o natural ou o sintético, é um corante alimentar aprovado sem certificação).

\section{CORANTES CERTIFICADOS}

No mercado dos EUA os corantes certificados são usados amplamente em uma grande variedade de alimentos.

Os corantes FD\&C solúveis na água, podem transformar-se em pós insolúveis (lacas) por precipitação com sais de alumínio, cálcio ou magnésio sobre um substrato de hidróxido de alumínio. Os precipitados são 
secos, triturados finamente e são vendidos como classes separadas de corantes alimentícios. 0 conteúdo de corante varia de 10 a $40 \%$.

As lacas podem ser preparadas a partir de todas as classes de pigmentos indicados acima. A insolubilidade das lacas na água, azeite e gorduras, confere certas vantagens sobre os corantes hidro e lipossolúveis. São mais estáveis ao calor e a luz e não emigram. São usados extensamente em produtos de confeitaria, produtos de padaria, preparados para saladas e substitutos do chocolate, nos quais não é desejável a presença de água. Também são muito usadas na indústria de enlatados, na qual as películas e as tintas estão em contato com o alimento e nos tabletes farmacêuticos.

\section{CORANTES ISENTOS DE CERTIFICAÇÃO}

Os corantes que são isentos de certificação são controlados pelo FDA para assegurar que sua pureza está de acordo com as especificações e que são usados em consonância com a legislação. Obviamente, o uso de muitos destes aditivos é autolimitado devido ao "flavor", cor, preço, etc. Muitas preparações têm um duplo uso; por exemplo, os sucos de frutas e hortaliças podem ser classificados mais como ingredientes dos alimentos que como aditivos de cor. Pode existir uma sutil diferença entre ambos, a qual tem que ser decidida caso a caso. Analogamente algumas espécies (por exemplo, açafrão, cúrcuma e pimentão) têm um papel duplo como saborizantes e corantes.

Talvez a classe mais importante dos corantes isentos de certificação sejam os carotenoides. Os carotenoides estão contidos nos extratos naturais de urucum, açafrão, pimentão, tomates e outras fontes. Atualmente três carotenoides sintéticos estão aprovados pelo FDA para sua adição nos alimentos. 0 $\beta$ - caroteno, que proporciona uma cor de amarelo a laranja é o mais amplamente usado. $0 \beta$ - Apo-8carotenal proporciona uma cor laranja a vermelha e a cantaxantina dá uma cor vermelha. A cantaxantina é o carotenoide que tem alcançado uma grande importância, particularmente desde que foi proibido o uso do vermelho FD\&C no. 2. A síntese de carotenoides tem a grande vantagem de se poder controlar rigorosamente sua pureza e sua capacidade corante.

Outro carotenoide, a bixina derivada da semente do urucum é muito usada na indústria láctea. 0 açafrão, uma espécie exótica e cara, contém o carotenoide amarelo crocina.

As aplicações dos carotenoides como corantes dos alimentos podem ser divididas em duas categorias, para alimentos gordurosos e alimentos aquosos. 0 primeiro grupo compreende a margarina, manteiga e azeites que usualmente requerem uma suspensão de 20 - 30\% do carotenoide em um suporte oleoso. A estabilidade dos carotenoides adicionados desta maneira é muito boa. Os alimentos aquosos, tais como, bebidas, sopas, produtos lácteos, produtos cárnicos, xaropes ou macarrão requerem uma formulação de carotenoides diferente. É possível preparar carotenoides dispersos em água mediante formação de uma suspensão coloidal utilizando solventes miscíveis em água ou por emulsificação de soluções oleosas. Os carotenoides sintéticos apresentam-se como suspensões oleosas em forma de pequenas bolas recobertas de gelatina ou carboidrato, ou inclusive como microcristais dependendo de sua aplicação.

Os derivados de antocianina são utilizados desde muito tempo como corantes de bebidas. 0 termo geral "enocianina" refere-se a um produto obtido do cozimento das uvas depois da produção do vinho. 0 produto azul é uma mistura variável de polímeros e ordinariamente contém muito pouca ou nenhuma antocianina. Recentemente foi introduzido no mercado, corantes vermelhos ou azuis obtidos de subprodutos das uvas. Os vermelhos contêm compostos de baixo peso molecular, ordinariamente antocianinas monômeras, e os produtos azuis contêm polímeros de peso molecular muito maior.

Como corantes dos alimentos, têm recebido considerável atenção as preparações de betacianina obtidas da beterraba vermelha. Estes corantes ou são beterraba desidratada e moída, sumos normais ou sumos dessecados por atomização e contêm uma mistura de betaninas vermelhas e betaxantinas amarelas. A concentração de pigmento é de aproximadamente 1\%. São desejáveis preparações purificadas com concentrações de pigmentos mais altos, porém são necessários estudos de toxicidade que ainda não foram feitos.

Certo número de compostos têm sido utilizados assim mesmo como corantes. 0 vermelho de cochonila é extraído do inseto Coccus cacti; o pigmento é o ácido carmínico e sua laca insolúvel é o carmim. Do inseto Laccifer lacca é obtido o pigmento vermelho "lac". A curcumina é o pigmento amarelo da cúrcuma obtido dos rizomas da planta. 0 fungo Monascus purpureus produz um pigmento vermelho denominado "monascina", o qual ainda que ilegal nos EUA tem sido utilizado há muitos anos no Oriente. As clorofilas e seus estáveis sais potássicos também têm sido utilizados como corantes, particularmente para pasta. A 
substituição na clorofila, clorofilina e feofitina ou feofórbido do íon magnésio por cobre, produz corantes que são permitidos na Europa. Tem sido comercializado sob a denominação geral "complexo clorofila cobre". Nos EUA as clorofilas podem ser adicionadas aos alimentos somente como vegetais verdes, em cujo caso classificam-se como ingredientes alimentícios. A hemoglobina e alguns de seus derivados químicos mais estáveis são corantes alimentícios potenciais, porém seu uso na forma pura não foi sancionado.

\section{CARMIM, ÁCIDO CARMÍNICO}

Devido a grande resistência encontrada, principalmente internacionalmente, à adição de corantes artificiais a alimentos, criou-se a necessidade do estudo de corantes naturais. Esta substituição não é direta uma vez que as cores artificiais costumam ter um custo menor que as naturais, têm um espectro de tonalidade muito amplo e são mais estáveis. 0 carmim despertou um grande interesse, pela ampla faixa de tonalidade vermelha que é possível alcançar, substituindo, desta forma, os corantes sintéticos, em especial a eritrosina.

O carmim é a laca obtida do ácido carmínico extraído do inseto Dactylopius coccus comumente denominado cochonila. A cochonila é um inseto da família Dactylopiidae espécie Dactylopius coccus Costa. O inseto é parasita dos cactos das espécies Opuntia ficus-indica e Nopalea coccinellifera alimentando-se da seiva das folhas. 0 cacto se adapta bem as condições de clima e altitude. No entanto é bastante suscetível a umidade e a características do solo.

A cochonila teve sua origem no México, América Central e Peru. Antigamente existiam diversas teorias sobre o inseto: alguns acreditavam que se tratasse de uma matéria vegetal secretada pelos cactos, outros a consideravam animal. Somente no século XVII, o microscopista holandês Antonius Van Leewenhoek provou, cientificamente, que se tratava de um inseto.

Ainda segundo o mesmo autor, no século XII, o império Inca utilizava a cochonila para tingir tecidos e pintar cerâmica. No México do século XVI, os astecas utilizavam a cochonila para obter tons vermelhos e rosados. O México chegou a exportar cochonila no período colonial. Os espanhóis levaram a planta para a Europa e durante muito tempo exerceram monopólio sobre a produção industrial de carmim. Atualmente se explora a cochonila no México, Peru, Chile, Bolívia, Argentina, Espanha, São Salvador, Itália, África do Sul, Îndia, entre outros. Apesar disto, o carmim consumido no Brasil é praticamente todo proveniente do Peru.

O inseto tem como ciclo de desenvolvimento as fases de ovo, ninfa I, ninfa II, fêmea ou macho adulto. 0 macho passa ainda pelas fases de pupa e pré-pupa após ninfa II. Somente as fêmeas são utilizadas para extração do pigmento. Não apresentam asas e seu aparelho bucal fixa-se ao cacto sugando sua seiva. 0 macho serve somente para a reprodução da espécie. A vida das fêmeas dura em média 130 dias realizando-se duas mudas antes de chegar ao amadurecimento sexual. Este é alcançado cem dias após seu nascimento. Após 20 dias se dá a postura e então a fêmea morre lentamente.

As fêmeas depositam uma média de 500 ovos o que pode ocorrer em qualquer época do ano. A colheita é feita manualmente de 3 a 4 vezes ao ano e se realiza após 3 meses da infestação do cacto.

0 ácido carmínico é o principal agente corante da cochonilha e trata-se de uma hidroxiantraquinona ligada a uma unidade de glicose. Apesar de outros insetos da família coccoidea possuírem pigmentos parecidos com ácido carmínico estes pigmentos não possuem cor e estabilidade com a qualidade da cochonilha. Além disto, não se pode obter o carmim através destes pigmentos. 0 ácido carmínico é um ácido fraco, insípido e inodoro, cristaliza em forma de prisma de cor vermelho brilhante. É solúvel em água $(1 \mathrm{~g} / 100 \mathrm{ml})$, em álcool e ácido sulfúrico concentrado. É pouco solúvel em éter e insolúvel em benzeno, clorofórmio e éter de petróleo. Não possui ponto de fusão definido. Sua fórmula molecular é $\mathrm{C}_{22} \mathrm{H}_{20} \mathrm{O}_{13}$.

O pigmento forma sais com metais pesados conhecidos por carminatos. 0 ácido carmínico se decompõe pelo calor, se hidrolisa rapidamente por ebulição com ácido diluído produzindo carmim vermelho de decomposição, $\mathrm{C}_{11} \mathrm{H}_{12} \mathrm{O}_{7}$.

O ácido carmínico forma sais de diferentes colorações de acordo com o composto utilizado na precipitação como indicado a seguir: 


\begin{tabular}{|l|l|}
\hline \multicolumn{2}{|c|}{ SAIS DE ÁCIDO CARMÍNICO DE DIFERENTES CORES } \\
\hline Alumínio e Estanho & Escarlate \\
\hline Enxofre & Roxo \\
\hline Bário & Violeta Mate \\
\hline Cromo & Púrpura \\
\hline Ferro & Vermelho Acinzentado \\
\hline Chumbo & Vermelho Achocolatado \\
\hline Magnésio & Rosado \\
\hline Urânio & Verde \\
\hline Zinco & Roxo \\
\hline
\end{tabular}

A solução aquosa do pigmento precipitada por óxidos metálicos forma lacas verdadeiras que são a base de sua aplicação do corante. No pH de 4,8 tem coloração vermelha e no pH 6,2 violeta.

Já o carmim é um corante laca de alumínio ou laca cálcica de alumínio cuja principal matéria corante é o ácido carmínico obtido do extrato aquoso de cochonila.

As lacas são a precipitação de pigmentos e adsorção de corantes em base ou substrato insolúveis. A base normalmente é o hidrato de alumina.

O carmim possui grande quantidade de proteínas derivadas de partes do inseto durante a fase de extração do pigmento.

O carmim é pouco solúvel em água, insolúvel em álcool e éter. Em presença de ácido se torna laranja e em amônia se dissolve completamente com coloração vermelha intensa. Em sulfato de sódio não se descolore. Em solução de cloreto de cálcio se descora. Queima desprendendo odor de substâncias nitrogenadas e deixando poucas cinzas. 0 corante forma coloração violeta em presença de solução de hidróxido de sódio ou potássio a $10 \%$.

A estabilidade do ácido carmínico diminui com o aumento de $\mathrm{pH}$ além de sua cor ser sensível a exposição à luz. 0 carmim é completamente estável à luz, muito estável ao calor e a presença de agentes oxidantes. Tolera a presença de agentes redutores como o sulfito em níveis superiores a 150 ppm.

0 extrato de cochonila é estável ao calor até a temperatura de $100^{\circ} \mathrm{C}$. Sua estabilidade ao pH se dá na faixa de 2,2 - 8,0 a temperatura de $7 \stackrel{0}{\circ} \mathrm{C}$ sendo que não é estável em pH acima de 5,0 a altas temperaturas. Além disso não é influenciado pela atividade de água de substratos. Sua estabilidade a luz não é muito boa em pH 5,0 e temperatura de $25^{\circ} \mathrm{C}$. A cor se mantém constante em geleias armazenadas por noventa dias a temperaturas de $14^{\circ} \mathrm{C}$ e $25^{\circ} \mathrm{C}$.

O extrato de cochonila varia de laranja ao vermelho, dependendo do pH. Possui boa estabilidade a luz e oxidação, mas pequena ao $\mathrm{pH}$ e ataques microbiológicos. Desta forma é frequentemente preservado com benzoato de sódio. Estudos realizados em ratos de ambos os sexos demonstrou que o carmim quando administrado em doses diárias de até $500 \mathrm{mg} / \mathrm{kg}$ de peso corpóreo não é carcinogênico e não apresenta outros efeitos indesejáveis. Foi relatado apenas um caso de choque anafilático em presença de carmim.

Apesar do procedimento comercial ser um segredo mantido desde a antiguidade, muitos processos de obtenção do carmim podem ser usados.

Há alguns fatores que influenciam na extração do corante:

- temperatura: geralmente a extração se desenvolve com maior rendimento em quantidade extraída e velocidade quanto maior a temperatura de extração. No entanto, não se pode exceder um limite permitido para não haver perdas na qualidade do produto final.

- tamanho das partículas: as partículas menores são as que possuem maior área interfacial carmimlíquido, desta forma, a velocidade de transferência de massa é maior. No entanto, partículas muito finas dificultam a extração e impedem a livre circulação do líquido na filtração.

- $\quad$ agitação: a agitação aumenta a difusão e consequentemente a concentração de carmim.

- solvente: o solvente não pode ser tóxico e sua viscosidade deve ser baixa afim de facilitar a extração.

- tempo de extração: o tempo deve ser suficiente para que os sólidos possam se difundir no solvente. 
- secagem: a secagem tem como finalidade o aumento do tempo de armazenamento e transporte.

Comercialmente existem três produtos:

[1] Ácido carmínico: pigmento extraído da cochonila fresca ou seca. Utilizado como indicador da digestibilidade dos animais, para tingir tecidos, como indicador em análises volumétricas (titulação de álcalis, ácidos inorgânicos e alcaloides), como corante alimentício, possui valor medicinal e é utilizado na obtenção de pós dentifrícios de várias cores.

[2] Extrato de cochonila: é a solução aquosa do pigmento. Utilizado em indústria de alimentos e farmacêutica.

[3] Carmim: é a laca do corante. Complexação do ácido carmínico extraído da cochonila com metais, em especial o alumínio. Utilizado em alimentos como bebidas, sorvetes, iogurtes, recheio de biscoitos, cerejas em calda, balas, embutidos cárneos, massas com vegetais, bebidas lácteas em pó, xarope de frutas entre outros.

Todos os produtos têm coloração na faixa do vermelho. Sua principal diferença é o teor de pigmento, sendo a laca bastante estável.

Segundo a legislação é considerado "corante natural" o pigmento ou corante inócuo extraído de substância vegetal ou animal. A C.N.N.P.A em seu anexo II estabelece a cochonila e o ácido carmínico como corantes orgânicos naturais (C.I), o anexo III, estabelece ainda o carmim como corante natural.

É permitido o uso do carmim em alimentos processados a base de cereais, amargos e aperitivos, balas, caramelos e similares, batidas, cerejas em calda, cobertura e pós para cobertura de bolos, coberturas e xaropes para gelados comestíveis e sobremesas, "cooler", creme vegetal, gelados comestíveis, gomas de mascar, gorduras e compostos gordurosos, iogurtes aromatizados, leites aromatizados, leites gelificados aromatizados e licores. Em todos estes alimentos não existe limite máximo permitido. Em geléias o limite máximo permitido é $0,02 \mathrm{~g} / 100 \mathrm{~g}$. Internacionalmente o carmim é rotulado com o no. EEC no‥ E 120 .

\section{NOVOS CORANTES POSSÍVEIS}

No campo dos corantes tem surgido um novo conceito. Os extensos dados toxicológicos necessários quando se ensaia a inoquidade dos corantes tem a desvantagem de seu custo e das conotações para o consumidor. Obviamente, como os corantes são absorvidos pelo organismo, as possíveis consequências não desejáveis têm levado à ideia de conseguir corantes que não sejam absorvidos pelo intestino humano. O pioneiro desta ideia foi a companhia Dynapol que buscou um polímero de elevado peso molecular com componentes corantes e de solubilidade apropriados.

O esqueleto linear do polímero de uns 20.000 a 1.000 .000 de daltons pode ser obtido a partir de diversos materiais tais como ácido poliacrílico, polivinilamina e álcool polivinílico. Os grupos cromóforos estão unidos ao polímero por uma ligação carbono-nitrogênio estável. Tem-se preferido os cromóforos do tipo antraquinona, porém têm sido sugeridos outros cromóforos como azo, antrapiridona e benzantronas.

0 conceito implicado na ideia dos polímeros não se limita aos corantes. De fato, a primeira aplicação permitida pelo FDA foi com antioxidantes. Estão sendo desenvolvidos três corantes (vermelhos, amarelos e azuis). (Fonte: Costa; Rosa, 2016; Ribeiro; Seravalli, 2004) 


\section{Referências}

[1] ALLINGER, N.L., CAVA, M.P., DE JONGH, P.C., JOHNSON, C., LEBEL, N., STEVENS, C.L., Química Orgânica, Ed. Guanabara Dois; 2a ed. 1978; Rio de Janeiro/RJ.

[2] AMAYA, D.R.; BOBBIO, F. O.; BOBBIO, P.A. - Curso sobre Pigmentos Naturais SBCTA - Campinas/SP - Julho1984.

[3] AMERICAN ASSOCIATION OF CEREAL CHEMISTS (AACC). 1989. Approved Methods of the American Association of Cereal Chemists. $11^{\text {a }}$ ed. St. Paul, Minnesota.

[4] AMERICAN ASSOCIATION OF CEREAL CHEMISTS (AACC).1995. Approved Methods Cereal Laboratory Methods (9th ed), AACC Method 54-21 (Farinograph Method for Flour) - Association Cereal Chemists. St. Paul, Minnesota.

[5] ARAÚJO, J. M. A. Química de Alimentos - Teoria e Prática - 4aㅗ ed. Viçosa, MG: Ed. UFV, 2008. 596p.

[6] ARAÚJO, W. M. C.; MONTEBElLO, N. de P.; BOTELHO, R. B. A.; BORGO, L. A. Alquimia dos Alimentos - Brasília: Editora Senac - DF, 2007.560p.

[7] ATWELL, W. A; HOOD, L. F.; LINEBACK, D. R.; VARRIANO - MARSTON, E. e ZOBEL, H. F. 1988. The Terminology and Methodology Associated with Basic Starch Phenomena. Cereal Foods World 33:306-311.

[8] AZEVEDO, G.W. de - Corantes - p.16-27; 1981.

[9] BALTES, W. Química de los Alimentos. Editorial Acribia, S. A. Zaragoza - España, 2007. 476p.

[10] BARROS NETO, B.; SCARMINIO, I. S.; BRUNS, R. E. 1995. Planejamento e Otimização de Experimentos. Campinas: Editora da UNICAMP, p.187-216.

[11] BARUFALDI, R.; OLIVEIRA, M. N. de. Fundamentos de Tecnologia de Alimentos - vol. 3 - São Paulo: Atheneu Editora, 1998.317p.

[12] BAYNES, J. W.; DOMINICZAK, M. H. Bioquímica Médica - Rio de Janeiro: Elsevier, 2010. 653p.

[13] BERGTHALLER, W., von. 1971. Preparation of Phosphoric Acid Esters of Starch. I. Influence of Addition of Phosphate and Time of Heat Treatment on Phosphate Content and Rheological Behavior. Die Stärke. Stuttgard. 23 (3) 73-79.BETTELHEIM, F. A,; BROWN, W. H.; CAMPBELL, M. K.; FARREL, S. O. -

[14] Introdução à Bioquímica - - São Paulo: Cengage Learning, 2012. 781p.

[15] BETTELHEIM, F. A, LANDESBERG, J., LEE, J. Laboratory Experiments for General, Organic and Biochemistry. Saunders College Publishing, 1995, 552p.

[16] BETTELhEIM, F. A \& MARCH, J. Introduction to General, Organic and Biochemistry. Saunders College Publishing, 1995, 738p.

[17] BROUNS, F., KETTLITZ B., ARRIGONI E.Resistant starch and "the butyrate revolution". Trends in Food Science and Technology 2002; 13(8): 251-61.

[18] BROWN, T. A.; Bioquímica. 1 Ed. - Rio de Janeiro: Guanabara Koogan, 2018. 512p.

[19] CAMPBELL, M. K. Bioquímica. 3a ed. Artmed Editora Ltda., 2003, 752p.

[20] CAMPBELL, M. K.; FARREL, S. O. Bioquímica Básica - vol. 1 - São Paulo: Cengage Learning - 2011, 263p.

[21] CAMPBELL, M. K.; FARREL, S. O. Bioquímica - vol. 2. Biologia Molecular - São Paulo: Thomson Learning 2007.

[22] CAMPBELL, M. K.; FARREL, S. O. Bioquímica - vol. 3. Bioquímica Metabólica - São Paulo: Thomson Learning 2008.

[23] CAMPBELL-PLATT, G. Ciência e Tecnologia de Alimentos. Barueri, SP: Manole, 2015. 536p.

[24] CAMERON-SMITH D, COLLIER GR. Dietary fiber and glucose metabolism and diabetes. Handbook of dietary fiber. In: Cho ss, Dreher ML (eds.)., New York: Marcel Dekker INC, 2001, p. 107-23.

[25] CAPRONI, E. e BONAFACCIA, G. 1989. Azione del Glutine Vitale su Alcune Caratteristiche Reologiche degli Impasti di Sfarinati di Tenero. Tecnica Molitoria - 497.

[26] CARMINE - The Natural Resource - Warner Jenkinson Company.

[27] CASCON, S.C.; CARVALHO, M. P. M.; MOURA, L. L.; GUIMARÃES, I. S. S.; PHILIP, T. - Corantes de Batata Doce Rocha Para Uso Em Alimentos - Boletim de Pesquisa - no. 9 - Abril/84. EMBRAPA - Centro de Tecnologia Agrícola e Alimentar - CTAA - Rio de Janeiro/RJ. 
[28] CHAMP, M. 1992. Determination of Resistant Starch in Foods and Food Products: Interlaboratory Study. European Journal of Clinical Nutrition. 46(2): S51-S62.

[29] CHAMPE, P. C.; HARVEY, R. A. Bioquímica Ilustrada. 2ª ed. Editora Artmed Ltda., 1996, 446p.

[30] CHAMPE, P. C.; HARVEY, R. A.; FERRIER, D. R. Bioquímica Ilustrada. 4ª ed. Artmed Editora Ltda., 2009, 528p.

[31] CISTERNAS, J. R.; VARGA, J. ; MONTE, O. Fundamentos de Bioquímica Experimental. 2ª ed. Editora Atheneu, 2001, 276p.

[32] COLLINS, P.; TIMBERLAKE, C. - Recent Developments of Natural Food Colours - Overseal Foods - U.K., 1993.

[33] CLYDESDALE, F. M.; A cor como um fator na escolha dos alimentos, pp. 83 -101 - Departamento de Ciência dos Alimentos. Universidade de Massachusetts, Amberst, M. A. 2009

[34] CONN, E. E. \& STUMPF, P. K. Introdução à Bioquímica, Edgard Blucher Ltda, 1980, 525p.

[35] CORONA, J.; CORONA, N. Faz bem pra quê? - A ciência por trás dos alimentos. 1. Ed. - Rio de Janeiro: Senac Rio de Janeiro, 2016. 352p.

[36] COSTA, N. M. B.; ROSA, C. de O. B. Alimentos Funcionais - componentes bioativos e efeitos Fisiológicos - 2 ed. Rio de Janeiro: Editora Rubio, 2016. 504p.

[37] COUlTATE, T. P. Alimentos - a Química de seus componentes. 3a ed. - Porto Alegre: Artmed, 2004. 368p.

[38] CUMMINGS, J. H.; BEATTY, E. R.; KINGMAN, S. M.; BINGHAM, S. A e ENGLYST, H. N. 1996. Digestion and Physiological Properties of Resistant Starch in the Human Large Bowel - British Journal of Nutrition. 75. $733-747$.

[39] DAMODARAN, S.; PARKIN, K. L.; FENNEMA, O. R. Química de Alimentos de Fennema - 4aa ed. - Porto Alegre: Artmed, 2010. 900p.

[40] ENGLYST, H. N.; KINGMAN, S. M.; CUMMINGS, J. H. 1992. Classification and Measurement of Nutritionally Important Starch Fractions. European Journal of Clinical Nutrition. 46 (suppl. 2) S33-S50.

[41] ESKIN, N. A. M. - Biochemistry of Foods - 2ª ed. - Academic Press, Inc. - Toronto.

[42] EVANGELISTA, J. Alimentos; um estudo abrangente: nutrição, utilização, alimentos especiais e irradiados, coadjuvantes, contaminação, interações. - São Paulo: Editora Atheneu, 2005. 449p.

[43] EVANGELISTA, J. Tecnologia de Alimentos - São Paulo: Editora Atheneu, 1998. 652p.

[44] EVANS, M. e SHRONTS, E. 1992. Intestinal Fuels: Glutamine, Short Chain Fatty Acids and Dietary Fiber. J. Am. Diet. Assoc. 92:1239.

[45] FENNEMA, O.R. - Química de Los Alimentos - 2ª ed.; 1993. Editorial Acribia, S. A - Zaragoza (España).

[46] FRANCO, B. D. G. DE; LANDGRAF, M. Microbiologia dos Alimentos - São Pulo: Editora Atheneu, 1996. 182p.

[47] FRANCO, C. M. L. \& CIACCO, C. F. 1992. Factors that Affect the Enzymatic Degratation of Natural Starch Granules - Effect of the Size of the Granules Starch/Starke. 44 (11): 422-426.

[48] FRANCO, G. Tabela de Composição Química dos Alimentos. 8ª ed. Livraria Atheneu Editora, 1992.

[49] FRENCH, D. 1984. Organization of Starch Granules. In: Whistler, R. L.; Bemiller, J. N. \& Paschall, E. F., Starch: Chemistry and Technology. London. Academic Press Inc. Cap. 7. p. 183-247. $2^{\mathrm{a}}$ ed.

[50] FISK, C. H.; SUBBAROW. 1925. The Colorimetric Determination of Phosphorus. J. Biol. Chem. 66:375.

[51] GEE, J. M. e WORTLEY, G. M. 1992. Effects of Resistant Starch on Intestinal Structure and Function. In: 'Intestinal Cell Proliferation with Emphasis on Dietary Manipulation. Report of a European FLAIR Concerted Action Workshop'. (Gee, J. M., and Nagengast, F. M., Eds) San Remo. Italy.

[52] GERMANO, P. M. L.; GERMANO, M. I. S. Higiene e Vigilância Sanitária de Alimentos. 5a ed. - Barueri, SP: Manole, 2015. 1075p

[53] GHIASI, K.; HOSENEY, R. C.; VARRIANO - MARSTON, E. 1982. Effects of Flour Components and Dough Ingredients on Starch Gelatinization. Cereal Chem. 60(1):58-61.

[54] GUIMARÃES, I. S. S.; CARVALHO, M.P.M.,; PHILIP, T. - Concentrado de Antocianinas de Malvaviscus arboreus. Boletim de Pesquisa no. 10 - Junho/1984 - EMBRAPA - Centro Nacional de Pesquisa de Tecnologia Agroindustrial de Alimentos - CTAA - Rio de Janeiro/RJ.

[55] GUIMARÃES, I. S. S.; CARVAlHO, M. P. M.; SUNDFELD, E.; PHILIP, T. - Corantes Naturais Para Alimentos: Antocianinas de Cascas de Uvas - Boletim de Pesquisa no. 11 - Julho/1984 - EMBRAPA - Centro Nacional de Pesquisa de Tecnologia Agroindustrial de Alimentos - CTAA - Rio de Janeiro/RJ.

[56] HARVEY, R. A.; FERRIER, D. R. Bioquímica Ilustrada. 5aㅡ ed. Porto Alegre: Artmed, 2012. 520p. 
[57] HEYNS, K. \& MAHLMANN, H. 1981. Zur Frage der Rolle des Phosphats in Phosphat modifizierten Stärken. Deutsche Lebensmittel - Rundschau. 77(4): 127 -134 (Food Science and Technology Abstracts 14(5): 5 L 357.

[58] HOOD, L. F. \& MERCIER, C. 1978. Molecular Structure of Unmodified and Chemically Modified Manioc Starches. Carbohydrate Research. 61: 53-66.

[59] HOSENEY, R. C. 1986. Principles of Cereal Science and Technology - American Association of Cereal Chemists, Inc. USA.

[60] JAY, J. M. Microbiologia de Alimentos - 6 ${ }^{\mathrm{a}}$ ed. - Porto Alegre: Artmed, 2005. 711p.

[61] JUNQUEIRA, L. C.; CARNEIRO, J. Biologia Celular e Molecular - 8. Ed. - Rio de Janeiro: Guanabara Koogan, 2005. 332p.

[62] JUNQUEIRA, L. C. U; CARNEIRO, J. Biologia Celular e Molecular - 9. Ed. - Rio de Janeiro: Guanabara Koogan, 2013. $364 p$

[63] KERR, R. W.; CLEVELAND JR., F. C. 1959. U. S. 2,884,413. Ortophosphate Esters of Starch.

[64] KITE, F. E. 1971. The Use of Phosphates in Food Products. In: DEMAN, J. M. \& MELNYCHYN, P. eds. Symposium: Phosphates in Food Processing. Ontario. The Avi Publishing Company. INC. p. 103-120.

[65] KOBLITZ, M. G. B. Bioquímica de Alimentos - Teoria e Aplicações Práticas. - Rio de Janeiro: Guanabara Koogan, 2008. 242p.

[66] LAJOLO, F. M.; MERCADANTE, A. Z. Química e Bioquímica dos Alimentos . V. 2. 1ํㅡㄹ ed. Atheneu, 2018.

[67] LEHNINGER, A L. Princípios de Bioquímica, Savier, 2002, 975p.

[68] LIAO, H.; CAI, Y.; HASLAM, E. - Polyphenol Interactions*. Anthocyanins: Co-pigmentation And Colour Changes In Red Wines. - J. Sci Food Agric. - 1992, 59, 299-305.

[69] LIBERATO, M. C. T. C.; MORAIS, S. M. Produtos Apícolas do Ceará e suas Origens Florais: características físicas, químicas e funcionais. - Fortaleza: EdUECE, 2016. 132p.

[70] LIBERATO, M. C. T. C.; OLIVEIRA, M. S. C. Bioquímica; V. 1, 1aㅡ ed. Assis, UECE. 2013. 176p.

[71] LIBERATO, M. C. T. C. Estudo Químico e Bioprospecção de produtos da abelha Apis mellifera L. do Estado do Ceará - Fortaleza: 2011. 232p. Orientadora: Selene Maia de Morais. Doutorado. (Doutorado em Biotecnologia) Universidade Estadual do Ceará, Fortaleza.

[72] LiBERATO, M. C. T. C. - Obtenção, Propriedades e Aplicação do Amido Resistente de Trigo. Fortaleza:2002. 92f. Orientador: Cláudio Ernani Mendes da Silva. Dissertação (Mestrado em Tecnologia de Alimentos) - Universidade Federal do Ceará, Fortaleza.

[73] LINEBACK, D. R.; WONGSRIKASEM, E. 1980. Gelatinization of Starch in Baked Products. Journal of Food Science. 45:71-74.

[74] LIU, H.; RAMSDEN, L.; CORKE, H. 1999. Physical Properties and Enzymatic Digestibility of Phosphorylated ae, wx, and Normal Maize Starch Prepared at Different pH Levels. Cereal Chem. 76 (6): 938-943.

[75] LODI, W. R. N.; RODRIGUES, V. Bioquímica: do conceito básico à clínica. São Paulo: SARVIER, 2012. 256p.

[76] MAHAN, L. K.; RAYMOND, J. L. Krause: Alimentos, Nutrição \& Dietoterapia, 14a edição, Rio de Janeiro: Elsevier, 2018, 1133p.

[77] MAHAN, L. K.; ESCOTT - STUMP, S.; RAYMOND, J. L. Krause: Alimentos, Nutrição e Dietoterapia, Rio de Janeiro: Elsevier, 13 ${ }^{\text {a }}$ edição, 2012, 1227p.

[78] MAHAN, L. K. \& ESCOTT - STUMP, S. Krause: Alimentos, Nutrição \& Dietoterapia. Roca, 11a edição, 2005, 1242p.

[79] MAIA, G. A; TIMBÓ, M. O P. P. - Urucum (Bixa orellana L), sua importância e aplicação como corante na indústria de alimentos - Seminário II - DTA UFC - Outubro /1992.

[80] MARTINS, A.P.; RUSIG, O. Carmim - Um Corante; Bol. SBCTA, 32 (I): 56-63, Jan/Ago 1998.

[81] MARZZOCO, A \& TORRES, B. B. Bioquímica Básica, Ed. Guanabara, 1990, 232p.

[82] MORAN, L. A.; HORTON, H. R.; SCRIMGEOUR, K. G.; PERRY, M. D. Bioquímica, 5. Ed. - São Paulo: Pearson Education do Brasil, 2013. 798p. MORRISON \& BOYD - Organic Chemistry; 3a ed. - Allyn and Bacon, Inc. Boston.

[83] MURRAY, R.K., GRANNER, D. K., MAYES, P. A, RODWELL, V. W. Harper's Biochemistry, Ed. Appleton \& Lange, 1996, 868p.

[84] NELSON, N. 1944. A Photometric Adaptation of the Somogyi Method for the Determination of Glucose. J. Biol. Chem. 153: 375-380. 
[85] NEUKOM, H. 1958. U. S. 2,865,762 - Pudding Mix.

[86] PASCHALL, E. F. 1964. Phosphation with Inorganic Phosphate Salts. in: WHISTLER, R. L. ed. Methods in Carbohydrates Chemistry: Starch. New York Academic Press. Vol. IV p. 294-296.

[87] PELLEY, J. W. Bioquímica. Rio de Janeiro: Elsevier, 2007, 230p.

[88] POMERANZ, Y. e CHUNG, O K. 1978. Interaction of Lipids with Proteins and Carbohydrates in Breadmaking. J. Am. Oil Chemists' Society. 55.

[89] PROGRAMA SAS SYSTEM FOR WINDOWS. 1996. Versão 6.12.

[90] PROSKY, L.; ASP, N. G.; SCHWEIZER, T. F.; DE VRIES, J. W. e FURDA, I. 1988. Determination of Insoluble, soluble and total Dietary Fibre in Food Products: Interlaboratory Study. $\mathfrak{T}$ Ass off Analyt. Chem. 71. 1017-1023.

[91] PYLER, E. J. 1973. Final Proof. Pages 672-681 in: Baking: Science and Technology. v. 2. E. J. Pyler. ed. Siebel Publishing: Chicago.

[92] REMIÃO, J. O. R; SIQUEIRA, A. J. S. de; AZEVEDO, A. M. P. de. Bioquímica - guia de aulas práticas. EDI-PUCRS, 2003. $214 p$.

[93] RIBEIRO, E. P.; SERAVALLI, E. A. G. Química de Alimentos. - São Paulo: Edgard Blücher: Instituto Mauá de Tecnologia, 2004.184p.

[94] RIEGEL, R. E. Bioquímica, Ed. Unisinos, 1996, 401p.

[95] RODWELL, V. W.; BENDER, D. A.; BOTHAM, K. M.; KENNELLY, P. J.; WEIL, P. A. Bioquímica Ilustrada de Harper. 30 Ed. - Porto Alegre: AMGH, 2017. 817p.

[96] ROSENTHAL, M. D.; GLEW, R. H. Medical Biochemistry - Human Metabolism in Health and Disease. John Wiley \& Sons, Inc. USA. 2009. 426p.

[97] RUTENBERG, M. W. e SOLAREK, V. 1984. Starch Derivatives: Production and Uses. Pages 312-388. In: Starch: Chemistry and Technology. 2nd ed R.L. Whistler, J. N., Bemiller, and E. F. Paschall, eds. Academic Press: London.

[98] SAJILATA MG, SINGHAL RS, KULKARNI PR. Resistant starch - a review. Comprehensive Reviews in Food Science and Food Safety. P. 1-17.

[99] SALAY, E. 1985. Produção, Caracterização e Propriedades de Pasta de Amido Fosforilado Obtido por Extrusão. Tese de Mestrado. FEA-UNICAMP, 90p.

[100] SALINAS, R. D. Alimentos e Nutrição: introdução à bromatologia 3 ed. - Porto Alegre : Artmed, 2002.

[101] SCHOCH, T. J. 1942. Fractionation of Starch by Selective Precipitation with Butanol. J. Am. Chem. Soc. 64:2957.

[102] SITOHY, M. Z. \& RAMADAN, M. I. 2001. Degradability of different phosphorylated starches and thermoplastic fims prepared from corn starch phosphomonoesters. Starch / Die Starke. 53(7) p.317-322.

[103] SMITH, R. J. e CARUSO, J. 1964. Determination of Phosphorus in: WHISTLER, R. L. ed. Methods in Carbohydrate Chemistry: Starch. New York. Academic Press. Vol. IV. p. 42-46.

[104] STRYER, L. Bioquímica, Ed. Guanabara Koogan, 1992, 881p.

[105] SWINKELS, J. J. M. 1985. Composition and Properties of Commercial Native Starches. Starch / Starke. 37(1):15.

[106] TAPCELL LC. Diet and metabolic syndrome: where does resistant starch fit in? Journal of AOAC International 2004; 87 (3): 756-60.

[107] TEDRUS, G. A S.; ORMENESE, R. C. C.; SPERANZA, S. M.; CHANG, Y. K.; BUSTOS, F. M. 2001. Estudo da Adição de Vital Glúten à Farinha de Arroz, Farinha de Aveia e Amido de Trigo na Qualidade de Pães. Cienc. Tecnol. Aliment. Campinas 21(1):20-25.

[108] THEANDER, O.; AMAN, P.; WESTERLUND, E; GRAHAM, H. 1990. The Uppsala Method for Rapid Analysis of Total Dietary Fiber. Adv. Exp. Med. Biol. 270:273-281. TYMOCZKO, J. L.; BERG, J. M.; STRYER, L. Bioquímica Fundamental - Rio de Janeiro: Guanabara Koogan, 2011. 748p.

[109] VAN MUNSTER, I. P. e NAGENGAST, F. M. 1992. Resistant Starch Decreases Faecal Secondary Bile Acids, Cytotoxicity of Faecal Water and Colonic Mucosal Proliferation. In: 'Intestinal Cell Proliferation with Emphasis on Dietary Manipulation. Report of a European FLAIR Concerted Action Workshop'. (Gee, J. M. e Nagengast, F. M. eds) San Remo. Italy.

[110] VASCONCELOS, N. M. S. de; LIBERATO, M. C. T. C.; MORAIS, S. M. de. Água e Alimentos: Química e Biotecnologia - Fortaleza: Edições Demócrito Rocha, 2004. 120p. What's Food Without Color? - Hilton Davis Co. Cincinnati, Ohio - EUA 
[111] WOLF, M.J. 1964. Wheat Starch Isolation. In: WHISTLER, R. L. Methods in Carbohydrates Chemistry. New York. Academic Press. Vol. IV.p. 18.

[112] WURZBURG, O. B. 1989. Modified Starches: Properties and Uses. $4^{\text {th }}$ ed. CRC Press Inc. Florida (USA) 288p.

[113] ZOBEL, H. F. e STEPHEN, A. M. 1995. Starch: Structure, Analysis, and Application. In: Food Polysaccharides. A. M. STEPHEN. ed. Marcel Dekker: New York. 19-66. 
